PhD Thesis

Examination of Grey Value Accuracy and Improvement of Image Quality in Cone Beam Computed Tomography (CBCT)

Mark Plachtovics, DMD

\author{
2015 \\ Szeged, Hungary
}




\title{
Examination of Grey Value Accuracy and Improvement of Image Quality in Cone Beam Computed Tomography (CBCT)
}

\section{PhD Thesis}

\author{
Mark Plachtovics, DMD \\ Department of Oral Surgery \\ Faculty of Dentistry \\ University of Szeged
}

\section{Graduate School of Clinical Sciences Research in Dental Medicine}

Supervisor: Dr.Katalin Nagy, DMD, PhD, DDS, Professor

Head of the Programme: Dr. János Minárovits, MD, DSc, Professor 


\section{Preliminary method oriented publications}

Plachtovics M. Digital Volume Tomography: Cone beam CT imaging in dentistry, oral and maxillofacial surgery (original article in Hungarian: A Digitális Volumentomográfia: Cone Beam CT-k a fogászatban, az arc-, állcsont- és szájsebészetben.)

MRadiol 2009;83:254-262.

Plachtovics M. Practical advice on the application of cone beam CT imaging in implantology I. (original article in Hungarian: Gyakorlati tanácsok a digitális volumentomográfia implantológiai alkalmazásához I.)

Implantológia 2011;8:22-27.

Plachtovics M. Practical advice on the application of cone beam CT imaging in implantology II. (original article in Hungarian: Gyakorlati tanácsok a digitális volumentomográfia implantológiai alkalmazásához II.)

Implantológia 2012;9:30-38.

\section{Publications directly related to the dissertation}

I

Paper 1: Plachtovics M, Patonay L, Kerenyi T. What Pal Szechenyi's tooth tells us: Modern investigation of a tooth with digital volume tomography. In Lilla Alida Kristof and Vilmos Toth (ed.): In honour of Archbishop Pal Szechenyi. Contribution for the path of life and the results of the study of the mummy of Nagycenk. (Original chapter and book in Hungarian: Amiről Széchényi Pál foga mesél. Korszerü fogvizsgálat DVT-vel. In: Széchényi Pál érsek emlékezete. Adalékok az életúthoz és a nagycenki múmia vizsgálatának eredményei.) Universitas-Győr Nonprofit Kft., 2012. Győr, Hungary. ISBN 978-963-981995-5. pp. 136-141.

\section{II}

Paper 2: Plachtovics M, Goczán J, Nagy K. The effect of calibration and detector temperature on the reconstructed Cone Beam CT image quality. A study for the work-flow of the iCAT Classic equipment.

Oral Surg Oral Med Oral Pathol Oral Radiol. 2015;119:473-480. doi: 10.1016/j.oooo.2014.12.009. Epub 2014 Dec 31. IF: 1.46 
III

Paper 3: $\quad$ Molnar G, Plachtovics M, Baksa G, Patonay L, Mommaerts MY. Intraosseous territory of the facial artery in the maxilla and anterior mandible: Implications for allotransplantation.

J Craniomaxillofac Surg. 2012;40:180-184. doi: 10.1016/j.jcms.2011.03.019. Epub 2011 Apr 1. IF: 1.61

IV

Paper 4: Plachtovics M, Bujtar P, Nagy K, Mommaerts MY. High-quality image acquisition by double exposure overlap in cone beam computed tomography.

Oral Surg Oral Med Oral Pathol Oral Radiol. 2014;117:760-767. doi: 10.1016/j.oooo.2014.02.024. Epub 2014 Mar 13. IF: 1.46

\section{Cumulative Impact Factor: 4.53}

\section{Additional publications}

Pataky L, Plachtovics M. About Cone Beam CT Imaging (original article in Hungarian: A Cone Beam CT-kröl.)

Dental Express 2006;9:3-6.

Plachtovics M. Of additional interest from the world of Cone Beam CT Imaging (original article in Hungarian: További érdekességek a 3D CBCT világából.)

Dental Hírek 2009;13:28-30. 


\section{Abbreviations}

AD

CBCT

CCD

COLD

$\mathrm{COLD}+\mathrm{C}$

$\mathrm{CP}$

CT

DVT

EMI

FOV

FPD

GE

$\mathrm{HU}$

ISI

LDPE

MDCT

MRI

MSCT

PET

RD

SCBCT

SD

TLD

US

WARM

$\mathrm{WARM}+\mathrm{C}$

WUP

2D

$3 \mathrm{D}$ apparent density

cone-beam computed tomography

charge-coupled device

COLD means that the CBCT acquisition was taken with no warming-up period and without calibration process of the flat panel detector.

$\mathrm{COLD}+\mathrm{C}$ is the abbreviation for the scan taken directly after the start of the equipment with cold detector but after the calibration process.

calibration process

computed tomography

digital volume tomography

Electric and Musical Industries Ltd

field of view

flat panel detector

General Electric

Hounsfield unit

Imaging Sciences International

low-density polyethylene

multidetector computed tomography

magnetic resonance imaging

multi slice computed tomography

positron emission tomographic imaging

raw data

sequential cone beam computed tomography

standard deviation

thermoluminescent dosimeters

ultrasonography

The WARM operation mode represents that the CBCT machine was switched on for at least two hours before the scan but no detector calibration was performed.

$\mathrm{WARM}+\mathrm{C}$ scan protocol is consistent with the cone beam computed tomography scan with the complete calibration sequence after the warming-up period. The two-hour warming-up period preceded the calibration process.

warming-up period

2 dimensional

3 dimensional 


\section{TABLE OF CONTENTS}

$1 \quad$ Historic Overview of Medical Imaging 1

1.1 Mapping-up the human body 1

1.2 Development of medical imaging 2

2 Introduction $\quad 8$

2.1 Overview of the technical development of dentomaxillofacial X-ray imaging 8

2.2 Basic principles of Computed Tomography (CT) 15

2.3 Dental Cone Beam CT imaging 16

$\begin{array}{lll}\text { 2.3.1 Nomenclature } & 16\end{array}$

$\begin{array}{lll}\text { 2.3.2 } & \text { Technical details } & 17\end{array}$

2.3.3 Advantages and disadvantages of dental CBCT 18

2.4 Various image artefacts in dental CBCT 20

2.4.1 Inherent artefacts $\quad 20$

2.4.2 Procedure-related artefacts $\quad 22$

$\begin{array}{lll}\text { 2.4.3 Introduced artefacts } & 23\end{array}$

2.4.4 Patient motion artefacts $\quad 23$

2.5 Quality improvement of images by post-processing methods 23

3 Aims 24

4 Materials and Methods $\quad 26$

$5 \quad$ Results and Discussion $\quad 29$

5.1 Focusing on X-ray scattering as the first basic problem 29

5.1.1 Examination of the magnitude of X-ray scattering on CBCT imaging 30

5.1.2 Examination of the possibility of mapping of dry soft tissue within a single tooth with the drastic reduction of X-ray scattering 32

5.2 Optimal density response for the dental CBCT imaging as the second basic problem; quality improvement by pre-processing and processing methods $\quad 34$

5.2.1 Steady-state temperature and the calibration of the FPD as the result of the pre-processing work-flow $\quad 34$

5.2.2 The calibration of the ideal concentration of the contrast material solution by mapping-up the angiosome of the human face

5.2.3 High-quality image acquisition in dental CBCT by using the concept of sequential cone beam computed tomography (SCBCT). The data collection as the third basic problem $\quad 44$

6 Conclusions $\quad 48$

7 Acknowledgments $\quad 50$

8 References $\quad 51$

9 Appendices A 


\section{$1 \quad$ Historic overview of medical imaging}

\subsection{Mapping-up the human body}

Throughout the ages, during different civilizations and various cultures, people were curious to know what is inside the human body. Although some of the driving force in this regard was related to medicine, there was nevertheless a recognizable quest for the development of anatomy.

The first European attempt, in the $2^{\text {nd }}$ century, was made by the Greek Galen of Pergamon (Figure 1) (Aelius Galenus or Claudius Galenus AD 129 - 216 [1]).

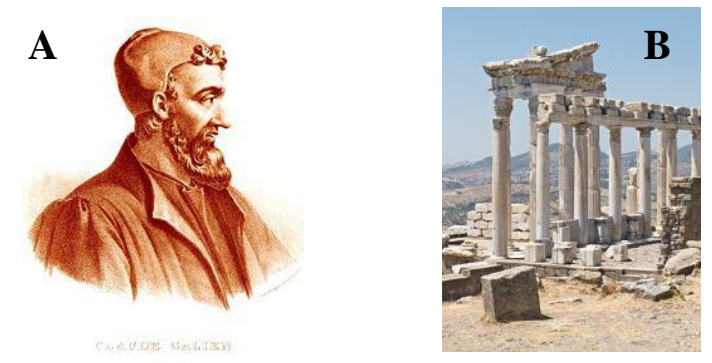

Figure 1 A: Artist impression of Galen. B: The ruins of Pergamon.

Galen's principal interest was in human anatomy but, from about 150 BC [2], Roman law had prohibited the dissection of human cadavers. Because of this restriction, Galen performed anatomical dissections on living (vivisection) and dead animals, mostly focusing on pigs and primates [3]. This work was useful because the anatomical structures of these animals usually closely mirror those of humans. Galen clarified the anatomy of the trachea, and was the first to demonstrate that the larynx generates the voice [4,5]. In one experiment, Galen used bellows to inflate the lungs of a dead animal. In his work De motu musculorum, Galen explained the difference between motor and sensory nerves, discussed the concept of muscle tone, and explained the difference between agonists and antagonists [5,6].

Andreas Vesalius (Figure 2 A) (31 December 1514 - 15 October 1564) was a Brabantian (from what is modern-day Belgium) anatomist, physician, and author of the most influential seven-volume books on human anatomy, De humani corporis fabrica (On the Fabric of the Human Body). Vesalius is often referred to as the founder of modern human anatomy. His work Fabrica was in strong contrast to many previous anatomical models because the basis of Vesalius's knowledge came from the anatomical dissection of the human 
body. He was a professor at the University of Padua and later became Imperial Physician at the court of Emperor Charles V.

A

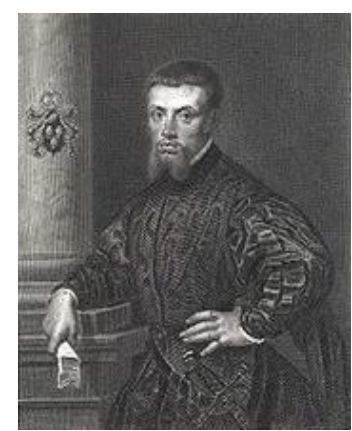

B

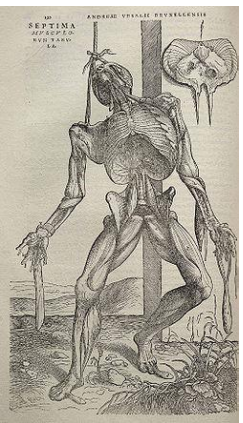

C

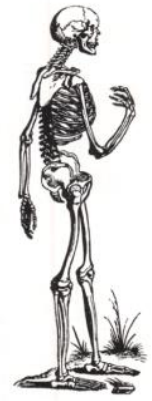

Figure 2 A: Portrait of Andreas Vesalius. $\mathbf{B}$ and $\mathbf{C}$ : Anatomic figures by Vesalius.

Vesalius's Fabrica contained many intricately detailed drawings of human dissections, often in allegorical poses. Such pictures are shown in Figure 2 B and C. The Fabrica emphasized the priority of dissection and what has come to be called the 'anatomical' view of the body, seeing human internal functioning as an essentially corporal structure filled with organs arranged in three-dimensional space. This was in stark contrast to many of the anatomical models used previously, which had strong Galenic/Aristotelian elements as well as elements of astrology.

This environment, which lasted from the second century (Galenius) to the sixteenth century (Vesalius), developed a strong desire to have the ability to see inside the human body [7].

\subsection{Development of medical imaging}

During many centuries the only way to visualize the inside of the human body was through dissection. With technical development, scientists had started to investigate the inside of the human body without its opening. In 1881, Alexander Graham Bell attempted to use magnets and sound waves to discover the location of the bullet that eventually killed U.S. President James A. Garfield [8].

After a lengthy period, during scientific experiments with various types of vacuum tube equipment, the discovery of X-rays in 1895, by the Bavarian physicist Conrad Röntgen, represented a major breakthrough (Figure $3 \mathbf{A}$ ). When X-rays were finally discovered, they found their way to medical applications within months [9]. 
The original discovery by Röntgen, at the Physical Institute, Julius-Maximilian University, Würzburg, Germany, is recorded to be on 8 November 1895 [9-17]. During the discovery, he speculated that a new kind of ray might be responsible for the observation. Since $8^{\text {th }}$ November was a Friday, instead of relaxing over the weekend, Röntgen took advantage of the time to repeat his experiments. In the following weeks he investigated many properties of the new rays he had temporarily termed 'X-ray'. In fact, he virtually lived in his laboratory during that time. The new X-ray is called the 'Röntgen ray' in many languages [18].
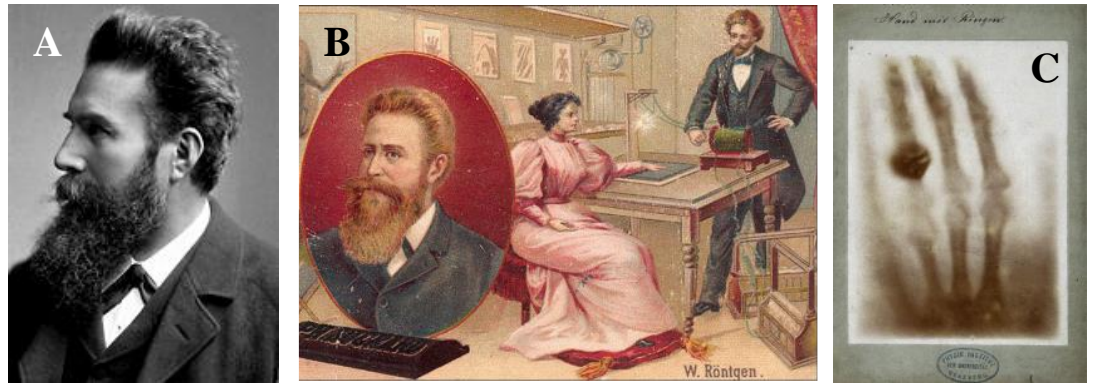

Figure 3 A: Wilhelm Conrad Röntgen (1845-1923). B: An artist's impression of Röntgen's work with Bertha Röntgen, his wife, producing the first medical X-ray image in early 1896. C: Hand with Rings: a print of one of the first of Wilhelm Röntgen's X-ray photographs. It shows the left hand of his wife [18].

Nearly two weeks after his discovery, he took the very first picture using X-rays of his wife Anna Bertha's hand. When she saw her skeleton she exclaimed 'I have seen my death!' (Figure 3 B and C) [10,18]. Röntgen receive the first Nobel Prize in Physics in 1901 [9,18].

The birthday of the Dental Radiograph is set at January 1896 by German dentist Otto Walkhoff (Figure 4 A) $[9-11,16,17]$. Needless to say, the world's first dental radiograph had no diagnostic value (Figure 4 B). While it did prove that the X-ray could be used in dentistry, it was an overexposure (twenty-five minute exposure) $[10,11,19]$ and also applied a high dose of radiation [11].
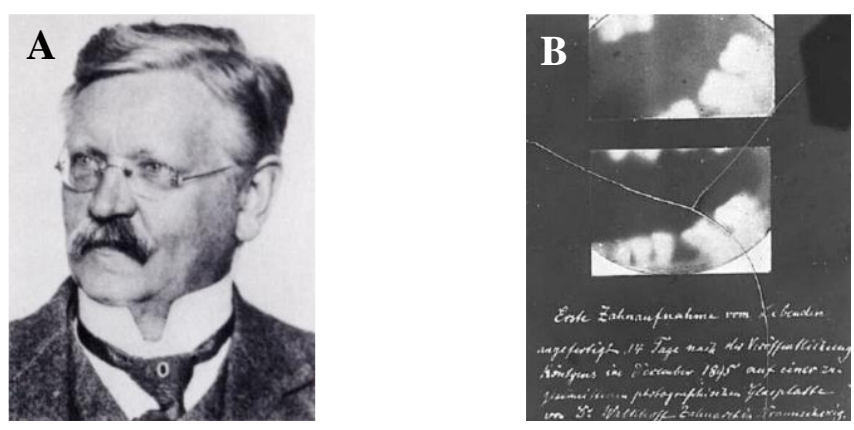

Figure 4 A: Otto Walkhoff (1860-1934) B: The first dental radiograph. 
Professor József Iszlai (1840-1903) was the first dentist in Hungary to recognize the importance of the X-ray in dentistry (Figure 5A) [9]. In a book by Henrik Salamon [20] published in 1942, one can find a description of a certain piece of equipment called a 'skiagram'. With this instrument, X-ray images could have been visualized directly without the use of a screen. At the beginning of the $20^{\text {th }}$ century, in Hungary, the medical community had already recognized the importance and usage of dental X-ray imaging. Consequently, in the newly opened Stomatology Clinic (Mária street 52, Budapest, Hungary) on 14 February 1909, an independent dental X-ray laboratory was established on the first floor [20].
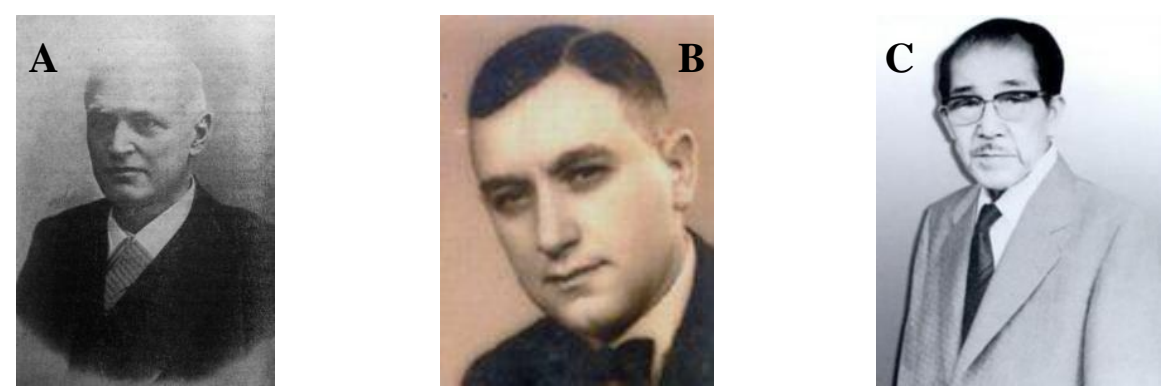

Figure 5 A: Professor József Iszlai in 1902. B: Gusztáv Grossmann (1878-1957). C: Dr Hisatugu Numata $[10,19,20]$.

William Herbert Rollins (1852-1929) was an American dentist and scientist who, in 1901, published the first paper about the dangers of X-ray radiation [19]. This publication was very timely because numerous irresponsible applications had appeared on the market (Figures $\mathbf{6} \mathbf{A}$ and $\mathbf{B})[10,11]$.
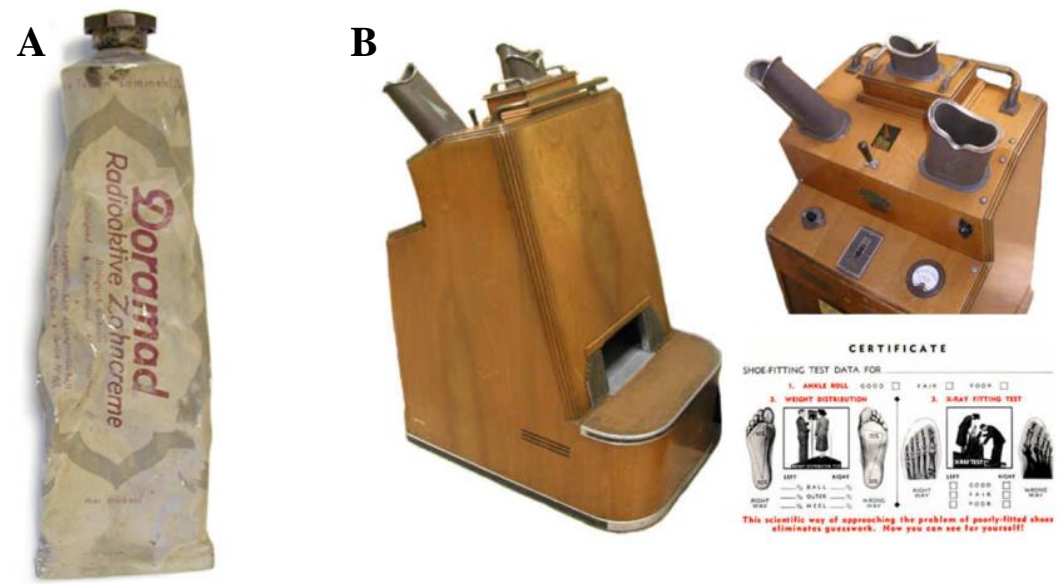

Figure 6 Illustrations of early irresponsible applications of radiation. A: 'Biologically effective' radioactive toothpaste. B: Photograph of a shoe-fitting test instrument. Public use prohibited in 1973 [10,11]. 
In 1914, the Polish radiologist Mayer first suggested the idea of section-imaging, a precursor of conventional tomography [21]. However, it took until 1930 to construct the first true conventional tomographic instrument. Tomography was invented by Gusztáv Grossmann, a Hungarian engineer. Grossman also coined the word 'tomography' (implying a graphic or picture of the slice) from tomos, a word of Greek or Latin origin, meaning a cut, cutting, slice, section. The classes of section-imaging techniques are summarized in Table I [22].

Table I The summary of the classes of section imaging (slice focusing) techniques [22].

\begin{tabular}{|l|l|l|}
\hline Class & Arrangement & Motion \\
\hline Statigraphy & $\begin{array}{l}\text { The X-ray tube and cassette are perpendicular to } \\
\text { a rigid pivoting pendulum }\end{array}$ & Linear, circular or spiral \\
\hline Planigraphy & $\begin{array}{l}\text { The X-ray tube and cassette move in parallel } \\
\text { equidistant planes with reciprocal motions }\end{array}$ & Linear, circular or spiral \\
\hline Tomography & $\begin{array}{l}\text { The X-ray tube and cassette are attached to a } \\
\text { rigid pendulum but the detector is always } \\
\text { parallel to the tomographic plane }\end{array}$ & Linear \\
\hline
\end{tabular}

In 1932, Gusztáv Grossmann (Figure 5 B) retreated from company management and, for the next decade, dedicated his life to scientific work. The result of this activity established the principles and practical solutions of tomography, effectively the X-ray imaging of a slice. He returned to Hungary in 1942 [22,23].

The necessity for imaging the jaws was already apparent during the first couple of decades of the $20^{\text {th }}$ century. A United State patent for a 'panoramic X-ray apparatus' was registered in 1922, by Alvin Frank Zulauf (Figure 7 A). This patent described a method whereby a narrow beam scanned both the upper and lower jaws. The 'object of this invention is to provide a U-shaped photographic film suitably protected with light-proof and waterproof material, to be inserted in the patient's mouth behind the teeth while they are being photographed. An X-ray generator which may be of any conventional type, is mounted upon a carriage and is adapted to be moved around the patient's mouth upon a curved table shaped in accordance with the contour of the patient's face and teeth'[24]. 

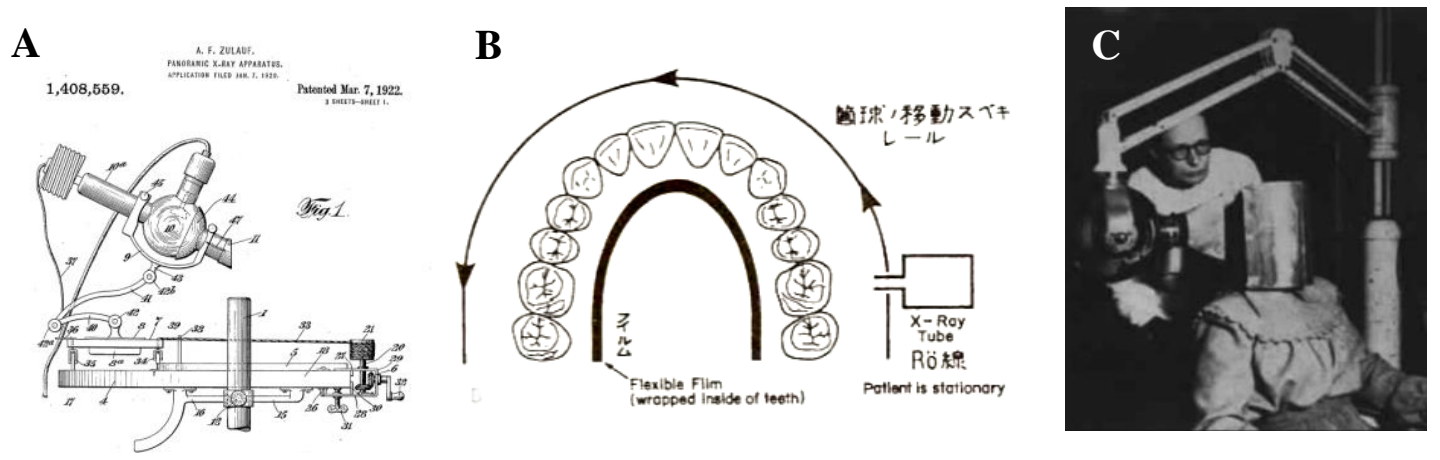

Figure 7 A: An illustration of the panoramic X-ray apparatus from the patent of Alvin Frank Zulauf. B: Scheme of the intraoral panorama imaging of Numata (Panography). C: Yrjo Veli Paatero with a patient and his equipment $[10,19,24]$.

Further development was made by Dr Hisatugu Numata (Figure 5 C) of Japan in 1933 $[10,19]$. His method represents the first panoramic radiograph, with a similar geometric arrangement to that of Alvin Frank Zulauf. In Numata's method the X-ray tube was outside of the mouth and moving in a hemi-circle while the film was in a U-fold form in the patient's mouth, as shown in Figure 7 B.

After much experimentation, a decade or so later Yrjo Veli Paatero of Finland started the actual tomographic method. Consequently, he is regarded as the "father of panoramic radiography'. In his work, he used a slit beam and a rotational technique (Figure $7 \mathbf{C}$ ). $\mathrm{He}$ published several papers on his clinical practice $[9,10,19]$.

Computed tomography (CT) could not become reality until the arrival of digital computer technology. Although digital computers didn't arrive on the scene until the 1960s, the mathematics of the application had already been created in 1917 [10,13,16,17,25-31], when Johann Karl August Radon (Figure 8 A) proved that the distribution of the materials in an object can be calculated mathematically [25].
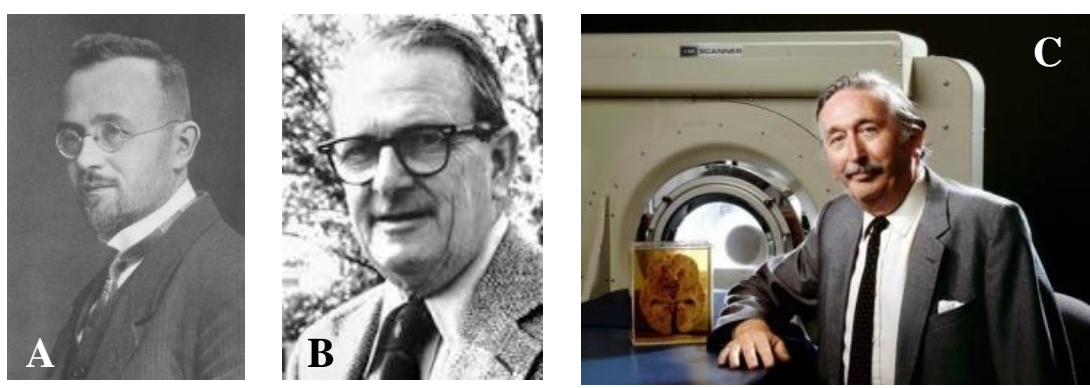

Figure 8 A: Johann Karl August Radon (1887-1956). B: Allan MacLeod Cormack (1924-1998). C: Godfrey Newbold Hounsfield (1919-2004) [13]. 
Independently, Allan MacLeod Cormack (Figure 8 B) developed a method to describe radiation absorption distribution in biological materials like the human body (1963) $[13,14,26]$.

The practical inventor of computer tomography is G. N. Hounsfield, an English engineer, who reached a functional solution in 1972 and published his results in 1973 [26]. He received the Nobel Prize in 1979, together with the physicist A. M. Cormack [9$14,16,17,27,28,32]$.

The story behind Hounsfield winding up in the business of computed tomography development is an interesting one. Columbia and the Gramophone Company, the two largest music companies, merged to become EMI (Electric and Musical Industries Ltd) in 1931. EMI, the music company, wanted to become one of the best electronics companies in the world. In this renewal process, they were active in the production of radar and television equipment. The world's first functional radar for fighter aircraft was delivered by EMI in October 1940. This EMI radar system was the precursor of the very successful so-called H2S radar system which helped to win the battle of the Atlantic. G. N. Hounsfield taught at Royal Air Force Cranwell, and was likely teaching about the H2S radar system. After the war, EMI built the first British all-transistor computer, called EMIDEC 1100 (Figure 9 A). By the 1960s, the EMIDEC 1100 was most successful large computer in the United Kingdom. However, a business storm emerged when the computer industry started the globalization process; EMI had no choice but to sell the EMIDEC computer business. The company had a very diverse business distribution: on the one hand, EMI was a music company; on the other hand, it was in the electronics business. The electronics business was definitely the smaller part, representing only $13 \%$ of the profit. The two aspects of EMI were run totally separately (the development of CT was not funded by the Beatles, as some people may believe). Nevertheless, in the emerging situation G. N. Hounsfield needed a new project; he ended up in development of the CT scanner (Figure 9 B). Thus, G. N. Hounsfield became the father of computer tomography (Figure 8 C) [28].
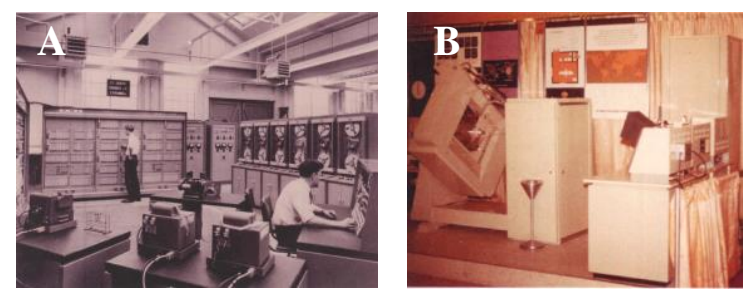

Figure 9 A: EMIDEC 1100 computer in the factory. B: The first official introduction of CT at the Radiological Society of North America (RSNA), May 1972, Chicago, USA [28]. 
It is remarkable that X-ray imaging started almost immediately after Röntgen's discovery of the X-ray. This is particularly impressive when note is taken of the many decades that usually separate a scientific discovery and its practical application. Galvani created an electric current in 1786; it was 1879 before the first electric power station was built in the United States. The early application of the X-ray made possible the arrival, at an unprecedented pace, of computed tomography.

The historical overview is summarized in Figure 10.

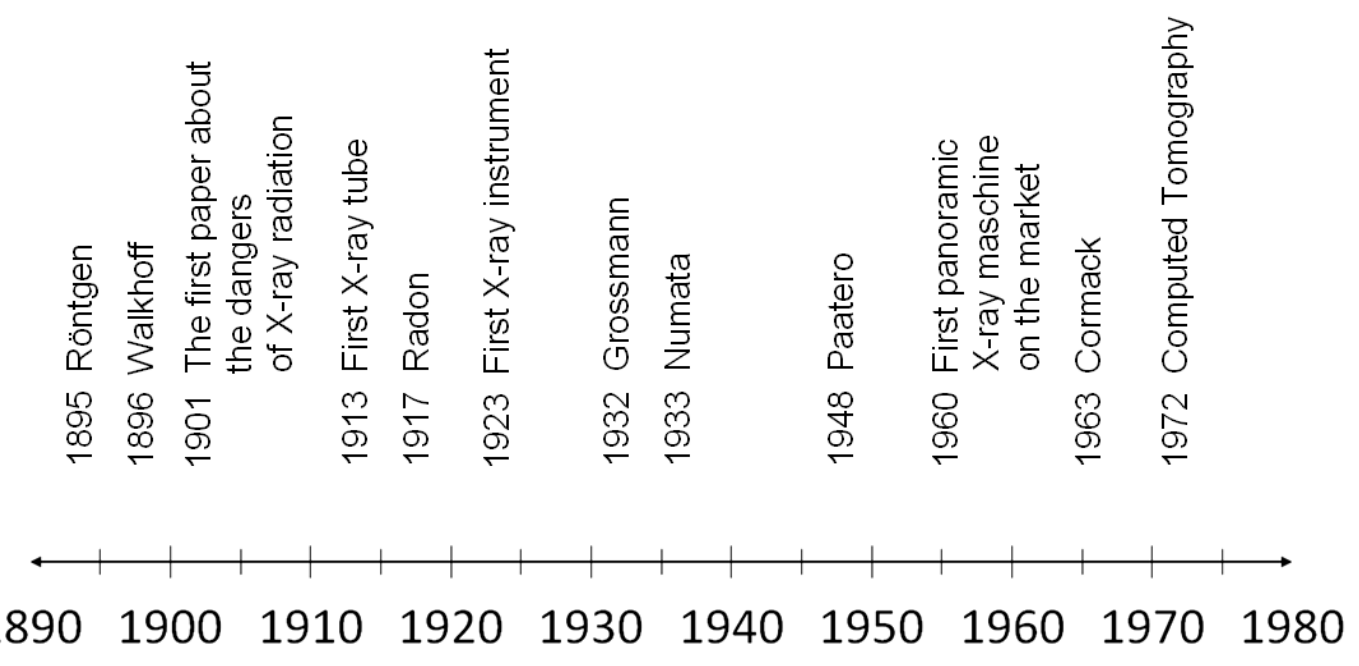

Figure 10 The early phase of $X$-ray imaging technique $[9,10,11,13,14,16,17,19,20,32]$.

\section{$2 \quad$ Introduction}

\subsection{Overview of the technical development of dentomaxillofacial X-ray imaging}

In 1972, Godfrey Hounsfield constructed the first CT equipment. In 1989, the first spiral CT appeared. Further work in the direction of Multi Slice CT (MSCT) or Multi Detector CT (MDCT) developed equipment producing, by 1998, four slices; in 2001, 16 slices; and, in 2004, 64 slices. The developers had a number of goals: better resolution, better image quality, and shorter acquisition time [13,14,16,17,32,33].

Dental and maxillofacial radiology has its own field of activity. The goal of dentomaxillofacial radiology is to achieve effective diagnostic image quality with a minimal amount of harmful radiation $[12,32]$. The intraoral radiograph and the panoramic radiograph are the most common acquisition techniques. These result in an overview picture of the whole dental status of the patient, either with a full mouth survey with the higher dose of radiation 
indicated for periodontal treatment or a panoramic radiograph with lower radiation dose. Various supplementary radiographs are also used. These include occlusal radiograph, transversal tomography, lateral cephalometric projection, submentovertex view or Waters projection, etc. Furthermore, dental Cone Beam Computed Tomography (CBCT) acquisition or Digital Volume Tomography (DVT) can also be used when three-dimensional (3D) imaging is necessary. In the case of some special indications, conventional Computed Tomography (CT), Magnetic Resonance Imaging (MRI) or sometimes Ultrasonography (US) acquisition should be used [16,17,32,33].

In the field of three-dimensional X-ray diagnostics, the conventional CT has an exceptional place with well-known advantages, and the usage has been limited only because of the high radiation dose. The main point of the acquisition is the image quality. The load of radiation only makes the field of indication narrow. In everyday practice, due to the higher radiation load of each high-quality conventional CT, it is preferred that the acquisition delivered to the doctor be taken with lower resolution, even though the diagnostic value of this scan cannot reach the desired level (Figure 11) [32].

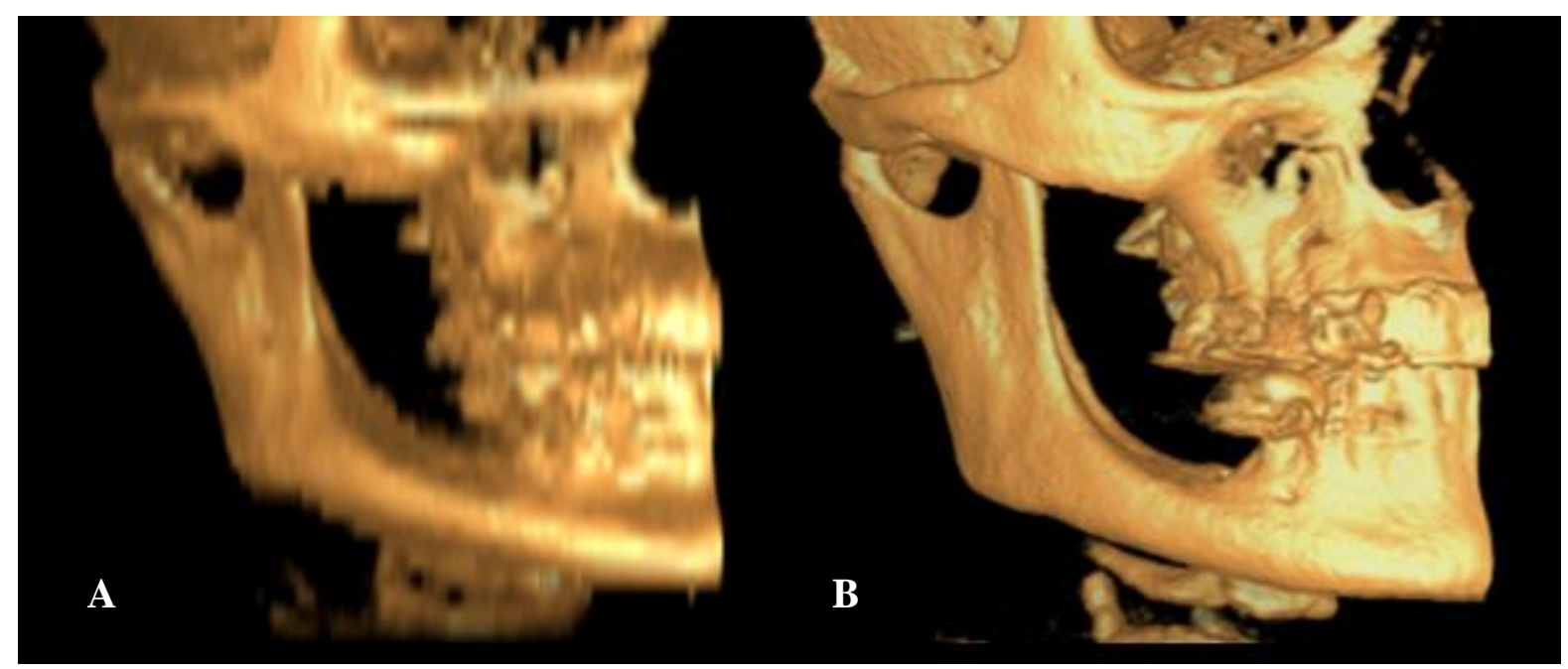

Figure 11 A CBCT scan reconstructed with two different method of resolution. The left hand side picture shows stair artefact. A: Low resolution CT reconstruction. B: Higher resolution, involving $0.3 \mathrm{~mm}$ slice thickness reconstruction typical for CBCT reconstruction [32,34].

This dental CBCT, or the digital volume tomography (DVT) technique, works with reasonable lower radiation coupled with the possibilities of high fidelity $3 \mathrm{D}$ imaging. This is focusing on the bony structures of the head and neck region. In Hungary, we have had the option of applying this technology since 2006 [32,35]. 


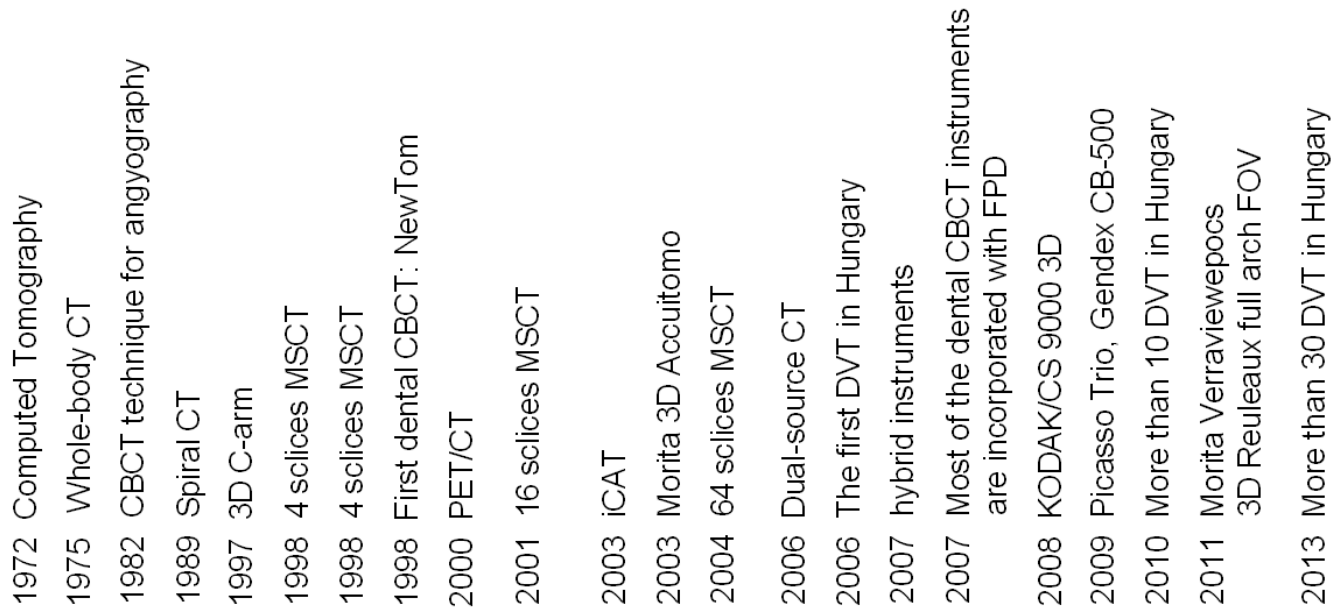

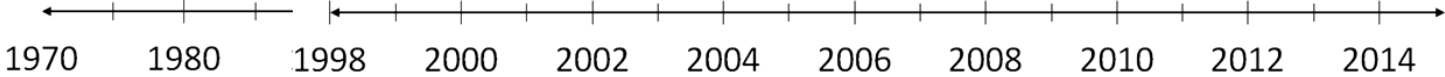

Figure 12 Overview of technical development of the dentomaxillofacial 3D X-ray imaging $[10,13,14,16,17,19,32]$.

The need to acquire several slices in a given time made it necessary to use new scanning geometry. For the 1 to 4 slices, CT fan beam geometry was acceptable (Figure $\mathbf{1 3}$ A). However, for the 16 and 64 slice MDCT instrument, cone beam or pyramidal beam acquisition geometry was necessary (Figure 13 B) [13,14,32].
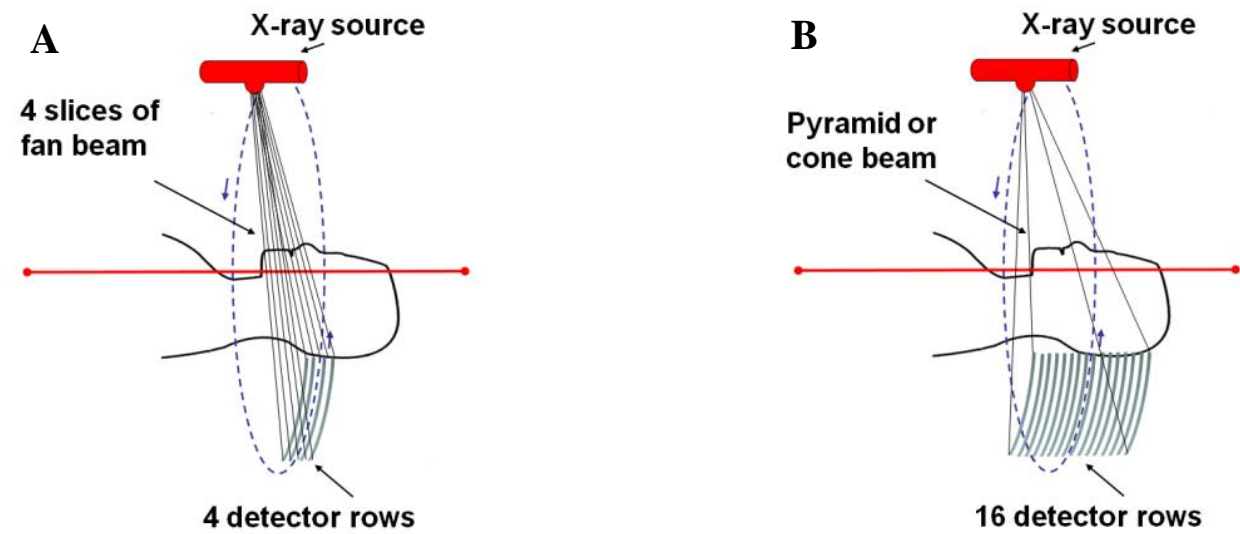

Figure 13 Schematic figures of two different MDCT acquisition modes. A: 1, 2, 4 slices conventional CT. B: 16 and 64 slice conventional CT [13,14,32].

The fan beam and cone beam nomenclature refers to the geometry of the radiation. At the present time, there is much equipment characterized as 'cone beam' (Figure 13 B), including numerous 16 -slice or more than 16-slice containing so called conventional CT, dual 
sources CT, PET CT, the C-arm, and several other instruments utilized in angiography and radiotherapy [12-14,32,36,37].

In order to reach a higher resolution, instead of using a one-dimensional detector twodimensional detector systems are used. Initially, these were image intensifier/charge-coupled device (CCD) systems (Figure 14 A, Figure 16 A and B). Later, flat panel detectors were used, mostly in interventional radiology (C-arm) and in angiography (Figure 14 B, Figure 16 C and D). Finally, technological development made it possible to reach a higher image resolution even with a low radiation dose [13,14,32].
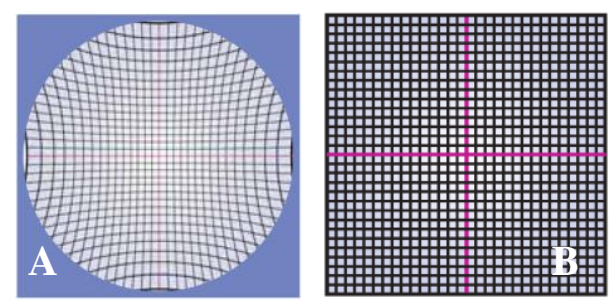

Figure 14 A: Projection image of a CCD image intensifier system. Distortion of grid is observed on moving away from the centre. Therefore no useful image can be found at the corners. Since the active detector is circular, cone beam is satisfactory. B: Projection image of a digital system (flat panel detector: FPD). There is no image distortion. Since the active detector is square, pyramidal beam is used [12,32,36,38-40].

Cone beam computed tomography (CBCT) was originally developed in 1982 for angiography $[16,17,36,41]$. More than a decade later, it was applied to dentomaxillofacial diagnostics. Finally, in 1997, the first dental CBCT equipment was manufactured; it was marketed in 1998. This equipment, the 'NewTom' (an abbreviation of 'new tomography'), had the appearance of a conventional CT in which the patient adopts a supine position during the acquisition (Figure 15 A). The detector was an image intensifier/charge-coupled device combination [12,32,36,41-43] (Figures 14 A, 16 A and B).
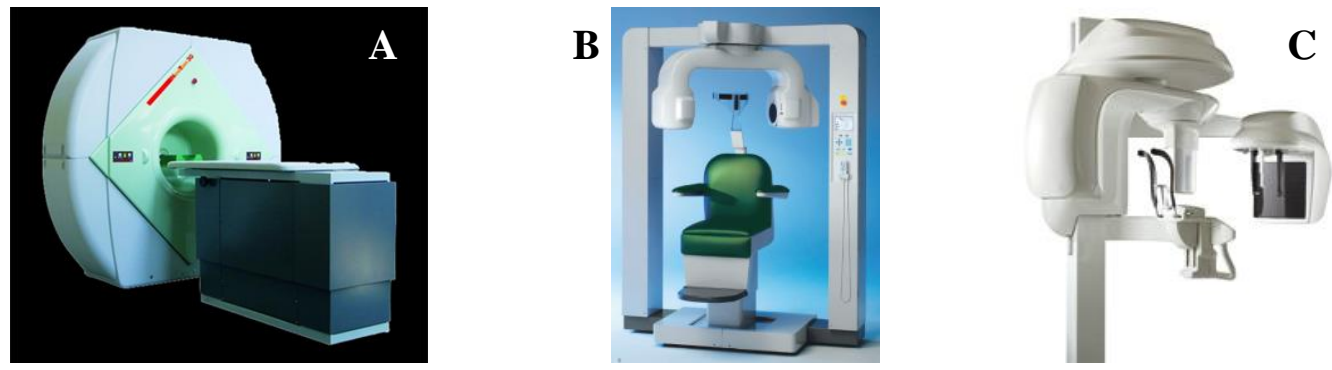

Figure 15 Examples of 3 CBCT equipments. A: NewTom QR-9000 (Quantitative Radiology, Verona, Italy). B: Accuitomo 3D (Morita, Kyoto, Japan). C: KODAK/CS 9000 3D (Carestream Health Dental GmbH, Stuttgart, Germany). 

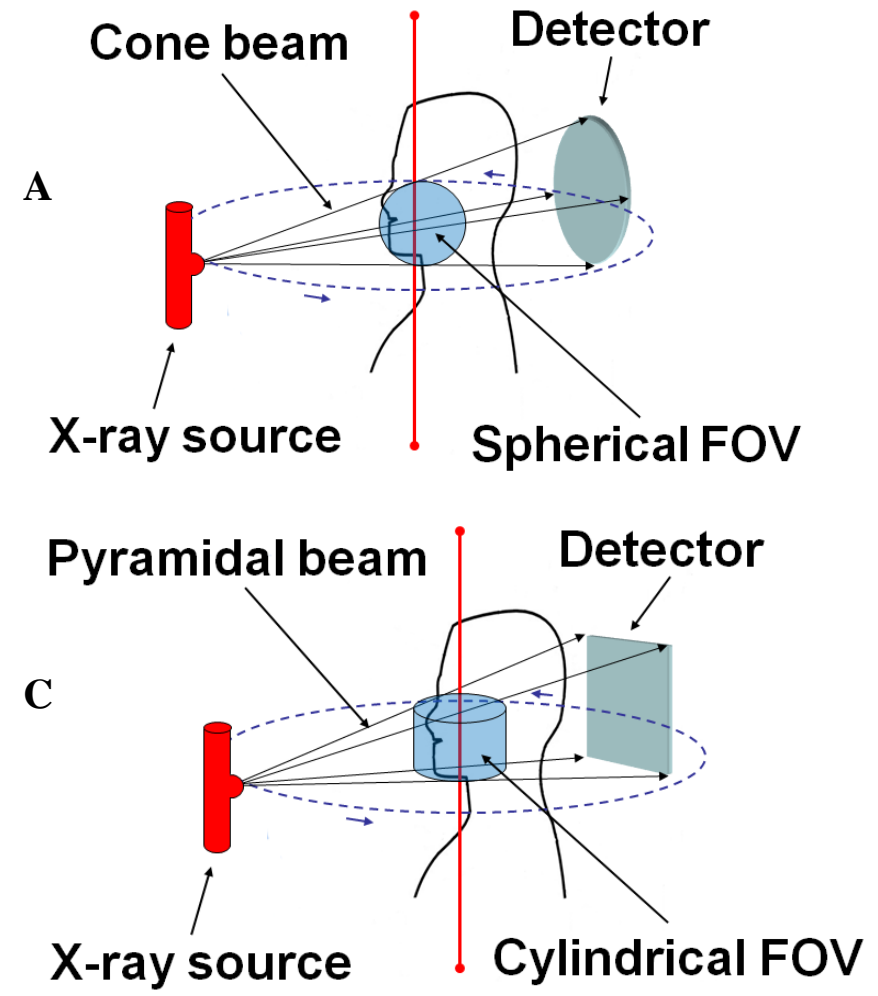

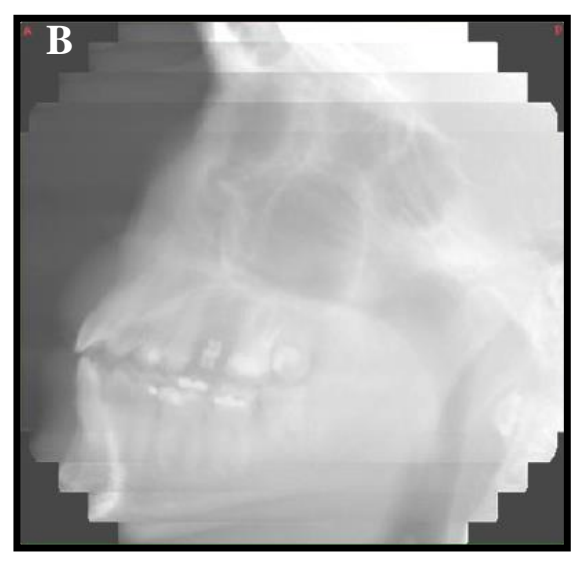

D

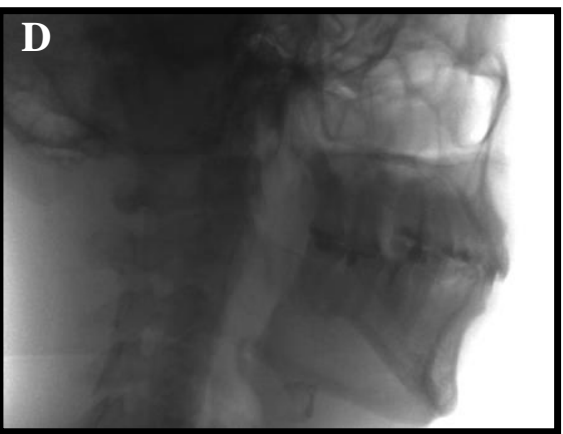

Figure 16 3D acquisition protocols with two different beam forms. A: Acquisition using cone shaped beam. B: Circle form basic projection image of the cone shape beam instrument (NewTom). The 3D reconstructed image is of spherically shape. C: Acquisition using pyramidal shaped beam. D: Square form basic projection image of the pyramid shape beam instrument (iCAT Classic). The 3D reconstructed image is cylindrically shaped [32,36].

The main advantages of dental CBCT are relatively high-resolution acquisition and, compared with conventional CT, lower radiation doses with smaller and less-expensive equipment [11,12,16,17,32,36,44-51].

The next milestone in development was in 2003, when J. Morita Mfg Corporation produced equipment with relatively small volume. In this instrument the patient was already in a seated position (Figure 15 B). The same year, Imaging Sciences International (ISI) produced its iCAT equipment, which used a flat panel detector (FPD); as can be seen in Figure 16 C and D. They were able to take a scan with the same diameter, in which height and resolution of the field of view (FOV) were controlled independently of one another [32,52]. Another novelty was the 'Extended Height' acquisition mode, 20+20-second exposition, 22-cm height optional extended field of view (EFOV) (Figure 17 A) [52,53]. 
A
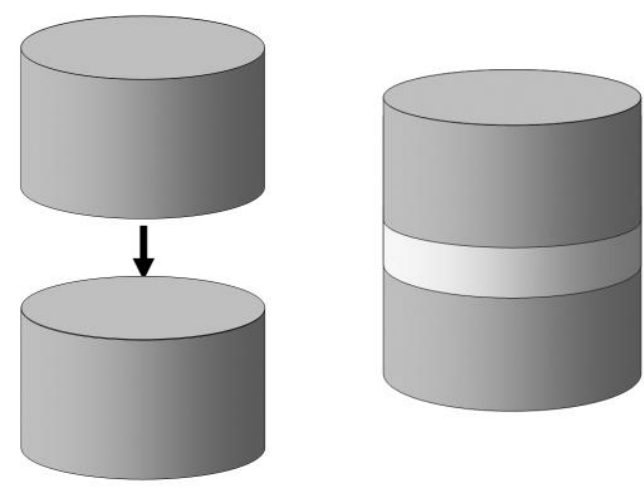

$\mathbf{C}$

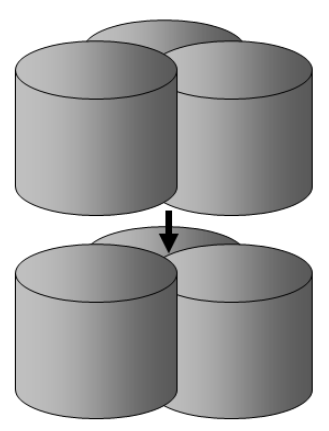

$\mathbf{E}$

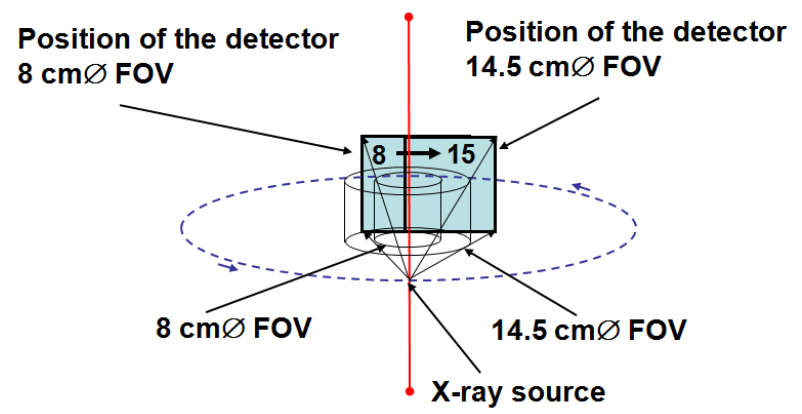

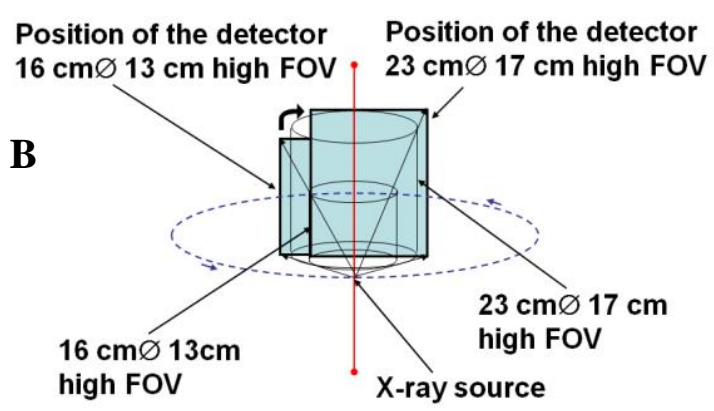

D

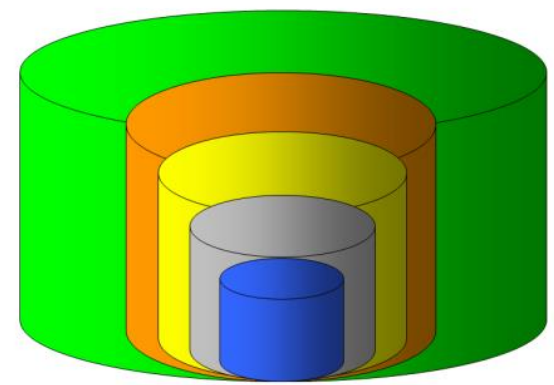

$\mathbf{F}$

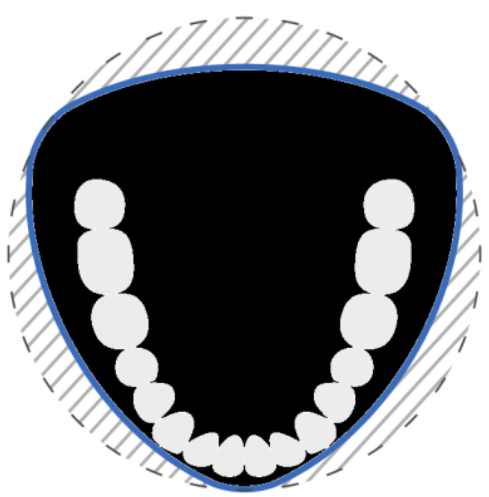

Figure 17 Various methods to increase the reconstructed volume by different dental CBCT equipment. A: The schematic representation of basic acquisition procedures. iCAT Classic 'Extended Height' acquisition $(20+20-$ second exposition, 22-cm height optional extended field of view (EFOV)), which was reconstructed during fusion of two separate 300 projections. The overlapping 4-cm-high region (EFOV 04) of the 22-cm height extended height acquisition mode (white colour marked, 300 raw data (RD) +300 RD) of the study configuration. The reconstruction of the EFOV 04 was made using both scans' RDs simultaneously $[52,53]$. B: In this equipment a 90-degree rotation of the detector could achieve a higher and larger diameter extended field of view (iCAT Next Generation/KaVo 3D eXam, Imaging Sciences International (ISI), Hatfield, PA, USA). Here the detector changed from a central to an off-set position [54]. C: Planmeca Promax 3D used to be used in 2009 to reconstruct the whole face of the patient by stitching together 6 separately-scanned medium-size volumes. D: 3D Accuitomo from Morita is designed to scan 6 different FOV using different resolutions. E: The 
Gendex CB-500 has the ability to take a scan with 2 different detector positions to have 2 FOV diameters. In this case the detector changed from a central to off-set position (Figure 19) [55]. F: 3D Reuleaux Full Arch FOV by MORITA Veraviewepocs 3D R100/F40 [56].

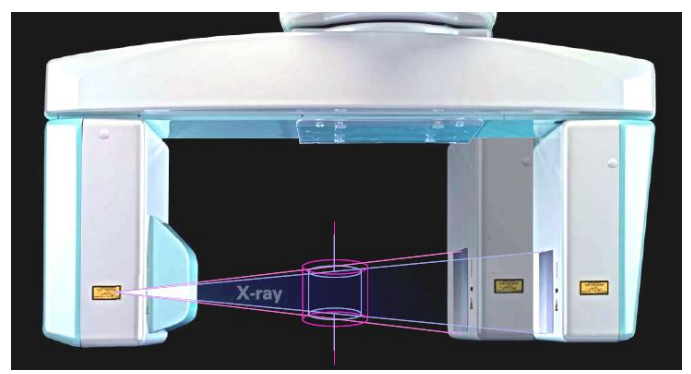

Figure 18 Flat Panel Detector (FPD) Automatic Positioning Function of the Morita 3D Accuitomo 80 instrument. 'For 40 x $40 \mathrm{~mm}$ and $60 \times 60 \mathrm{~mm}$ images, increasing the distance between the centre of the object being X-rayed and the FPD, the beams are almost parallel, delivering high-resolution images with no distortion' [57].

A

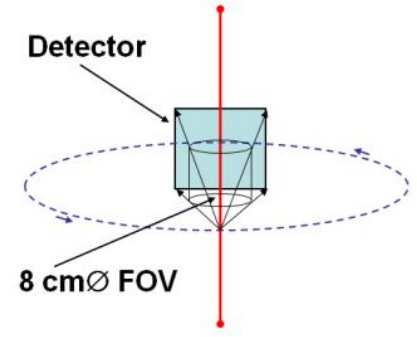

B

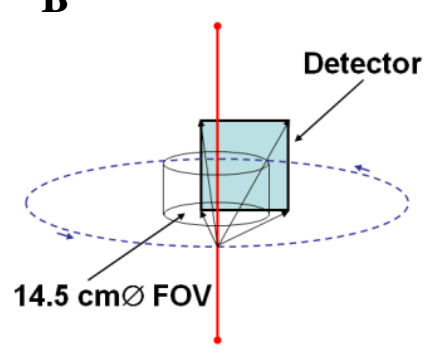

C

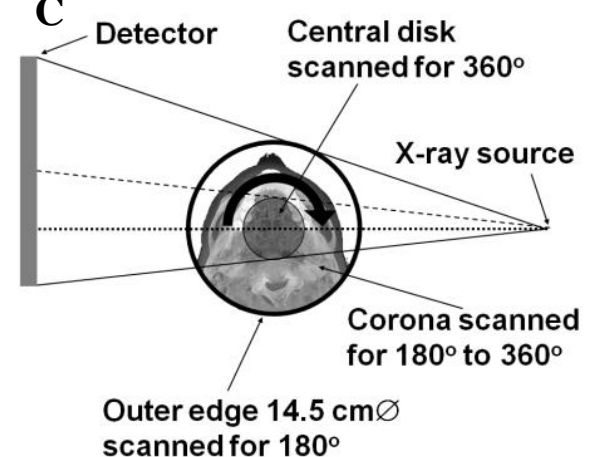

Figure 19 These images shows the schematic image of the two possible projection geometries during the acquisition resulting in two different diameter scans. A: Centre of rotation coincides with the line connecting the X-ray source with the centre of the detector. In the Gendex CB-500, this setup results in an $8 \mathrm{~cm}$ diameter FOV. B: Centre of rotation is off-set, relative to the line connecting the X-ray source, with the centre of the detector. In the Gendex CB-500, this setup results in a $14.5 \mathrm{~cm}$ diameter FOV. C: Cross-section of reconstructed volume generated by method off-set geometry. This image shows the three regions of the FOV [17,29,30,55].

Another breakthrough occurred in 2007, when most instruments incorporated FPD (3D Accuitomo FDP, NewTom VG, Picasso). For instance, 3D Accuitomo from Morita, at that time, was able to scan three different FOV using different resolutions (Figure $17 \mathbf{D}$ and 18) [57]. The iCAT NEXT Generation/KaVo 3D eXam enabled custom adjustment of the collimator position. It was possible to adjust, by the same FOV diameter, to the optimal height of FOV to reduce the patient radiation dose. In addition, the 90 degree rotation of the detector could achieve higher and larger-diameter extended fields of view (Figure 19 B) [54]. And last but not least, there appeared the so-called 'hybrid' or 'combi' instruments which were able to 
produce three different types of acquisition: dental CBCT, digital panoramic radiograph and digital cephalometric radiograph (Picasso Trio, Planmeca Promax 3D). Moreover, Planmeca Promax 3D at that time was able to reconstruct the whole face of the patient by stitching together six separately scanned medium size volumes (Figure 17 C). In 2008, high resolution small volume (KODAK/CS 9000 3D) was the novelty on the market (Figure 15 C), while in 2009 the medium size volume dental CBCT instrument created an explosion on the market (Picasso Trio, Gendex CB-500) [32]. With the Gendex CB-500, it was possible to take the scan with two different detector positions to have two FOV diameters (Figure 17 E) [55]. The details of this setup are illustrated in Figure 19. The next MORITA, Veraviewepocs 3D R100/F40, does not depict a cylindrical volume. The new Technology of Morita abandons the typical cylindrical FOV and uses a new convex triangle shape (Figure 17 F). According to the manufacturers [56], this 3D Reuleaux Full Arch FOV method more closely matches the natural dental arch form. Thus, the FOV reduces dosage by excluding areas outside the region of interest and allows a complete scan of the upper and/or the lower jaw.

\subsection{Basic principles of Computed Tomography (CT)}

Although it looks, rather simple, that soon after the patient enters a dental clinic a CBCT image is handed over to the doctor, a number of things must happen between these initial and final events. First of all, there is a data acquisition, using some type of X-ray radiation, collecting two-dimensional basic projections of digital images. This is treated as 'raw data' (RD) $[11,14,16,17,36,37,52-55,58]$. In a second step, a computer will analyse the collected two-dimensional basic projections. On the basis of the pixels of the RD, the computer calculates the position and density or grey value information of voxels of the 3D reconstructed volume. This process is the so-called primary reconstruction (Figure 20 A). From this reconstructed 3D database of the voxels, the particular structure of the human body which has been investigated appears (Figure 20 B) $[10,16,17,36]$.

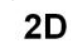

3D

A

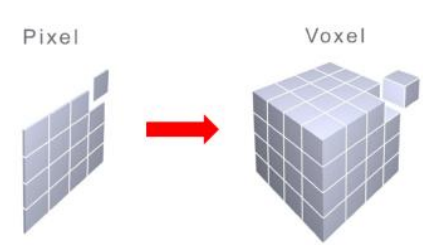

B

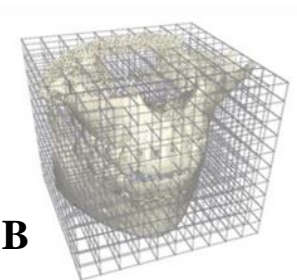

Figure 20 A: A schematic illustration of the pixel to voxel conversion performed by the computer (primary reconstruction). B: Image structure of the voxels generated during the primary reconstruction according to $\mathbf{A}$ $[17,59]$. 
Of course, there are always the questions: What do we measure in CT? and How do we compute a CT image? Clearly there is a mathematical background behind these two questions. The full mathematical background, which is based on Radon's original work $[10,13,14,16,17,25,29-31]$ in 1917 , may be presented in simplified fashion. The mathematical background is shown in the Appendix.

\subsection{Dental Cone Beam CT imaging}

\subsubsection{Nomenclature}

Cone Beam Computed Tomography (CBCT) is a collective noun used in Medical Science $[12-14,32,36,60]$. The dental CBCT is a special subsection of this large territory. In this section the focus will be on dental CBCT.

Several names exist for dental Cone Beam Computed Tomography (CBCT) technology in English, like Cone Beam Volumetric Imaging [40] or Digital Volume Tomography [15,58]. In Germany, they used the DVT abbreviation (Dental Volume Tomography or Digital Volume Tomography) rather than the CBCT abbreviation [1012,33,43,61]. There is a legal reason for this. In Germany, when the Cone Beam CT abbreviation is used, the inclusion of computed tomography demands that a radiology specialist must analyse the acquisition, which would represent an additional expenditure. A dentist, oral surgeon, maxillofacial surgeon cannot analyse conventional CT acquisitions [10$12,15,17,32,33,35,43,58,61-64]$.

There is also a practical reason; DVT is using lower-intensity radiation than conventional CT. Consequently, it makes only the structure of bone density materials visible in details on the acquisition picture but the soft tissue cannot visualized qualitatively $[11,37,39,43,65]$. In contrast, some cone or pyramidal beam using equipment, scanning with higher intensity X-ray, is able to show the quality of soft tissues (MDCT) $[13,14,29,66]$. The technological development increased the interest of other fields of specialization, such as ear, nose, and throat (ENT). These days the Digital Volume Tomography (DVT) expression is used very frequently. The $3 \mathrm{D}$ CBCT expression is correct, but not in the same sense as many people believe. Perhaps emphasizing the 3D is unnecessary, because both the conventional $\mathrm{CT}$ and CBCT acquisitions cover the three dimensions of the human body. During the process of taking a 2D X-ray picture, the X-ray itself is either cone- or pyramid-shaped. This is actually the $2 \mathrm{D}$ cone beam picture. In contrast, 3D acquisition occurs when, during the acquisition process, the X-ray moves around in a circle and results in a 3D database [32]. 
The precise nomenclature is very important since a disease of the soft tissue cannot be seen because the soft tissue can be visualized quantitatively the size but not qualitatively the structure in a DVT [11,15,37,39,42,43,67]. However, the soft tissue lesion would be qualitatively visible on a conventional CT. If a conventional CT is required but actually a DVT acquisition is made, then the disease may not recognized that could become a fatal mistake [32,35].

It has been pointed out previously that it would be reasonable to use the logical DVT expression in Hungary as well $[32,35,62,63]$.

\subsubsection{Technical details}

The quantity of X-ray tube radiation is directly proportional to the applied current (mA) and the length of the operation time. The quantity as well as the quality of radiation is dependent on the $\mathrm{kV}$ potential between the cathode and anode. With increasing $\mathrm{kV}$ applied, both the number of X-ray photons as well as the mean energy, that is, the frequency, of the Xray photons are increased. The level of radiation the patient is exposed to is directly related to these technical details [10,11,13-17,32,68].

In comparing the conventional $\mathrm{CT}$ and dental CBCT equipment, we see the following variations in these technical details. Of all the dental CBCT instruments available on the market at this time, the $\mathrm{kV}$ values applied can be grouped into three different classes. Most of the instruments operate within the $60-90 \mathrm{kV}$ range. Some instruments utilize potential in the 90-120 kV range, and a few instruments utilize $120 \mathrm{kV}$ as a single value [16,17,30,32,37,38,41,44-46,48,52-57,66,69-71]. In contrast, the conventional CT utilizes a higher voltage range: $80-140 \mathrm{kV}$. Where current intensity is concerned, the CBCT values range between 10-40 mA. In contrast, conventional CT imaging in the head and neck region may use as high a value as $120 \mathrm{~mA}[13,14]$.

For example, iCAT Classic equipment may be operated at values summarized in the following table (Table II) [52,53,72].

Of course, some of these machines operate in pulsed mode while others work in continuous mode $[16,17,36,38,41,52-57]$. In view of this, it may be noted that the iCAT Classic equipment, which operates in pulsed mode, results in an exposure time of only 3.5 seconds during a 20 -second long scan [15,52]. During this time the total radiation depends on the $\mathrm{kV}$ and $\mathrm{mA}$ values used [52,53,72], as specified in Table II. 
Table II. Parameters for the five different applied scans and reconstruction modes of the iCAT Classic 14-bit greyscale resolution dental CBCT imaging system. Equipment characteristics: Exposure type: pulsed [52,53,72].

\begin{tabular}{|c|c|c|c|c|c|}
\hline Abbreviation of acquisition mode & RD150 04 & RD300 04 & RD600 04 & RD600 02 & EFOV 04 \\
\hline $\begin{array}{c}\text { Number of raw data (RD) 2D } \\
\text { projections }\end{array}$ & 150 & 300 & 600 & 600 & $300+300$ \\
\hline Degrees of rotation & $360^{\circ}$ & $360^{\circ}$ & $360^{\circ}$ & $360^{\circ}$ & $360^{\circ}+360^{\circ}$ \\
\hline Slice thickness of the reconstruction & $0.4 \mathrm{~mm}$ & $0.4 \mathrm{~mm}$ & $0.4 \mathrm{~mm}$ & $0.2 \mathrm{~mm}$ & $0.4 \mathrm{~mm}$ \\
\hline Tube current (mA) & 9.65 & 18.45 & 36.12 & 36.12 & 18.45 \\
\hline Tube voltage (kVp) & 120 & 120 & 120 & 120 & 120 \\
\hline Diameter of the FOV (mm) & 154 & 154 & 154 & 154 & 154 \\
\hline Height of the FOV (mm) & 60 & 60 & 60 & 60 & 220 \\
\hline Scan times (seconds) & 10 & 20 & 40 & 40 & $20+20$ \\
\hline Exposure time (seconds) & 1.8 & 3.6 & 7.2 & 7.2 & $3.6+3.6$ \\
\hline Measured dose at detector (mGy) & 0.86 & 1.65 & 3.24 & 3.24 & $1.65+1.65$ \\
\hline
\end{tabular}

RD150 04, in our study, is the abbreviation for the scanning mode with 0.4-mm slice thickness, and the number of frames is 150. The RD300 04 operation mode represents the iCAT CBCT with 0.4-mm slice thickness, and the number of frames is 300 . The RD600 04 operation mode represents the iCAT CBCT with 0.4-mm slice thickness, and the number of frames is 600. The RD600 02 mode used the iCAT CBCT with 0.2-mm slice thickness, and the number of frames is 600. The EFOV 04 is the 4-cm height overlapping region of the iCAT Classic 22-cm height for Optional Extended Height acquisition with 0.4-mm slice thickness. This scan protocol consisted of two separate $13 \mathrm{~cm}$ height of 300 2D raw data (RD) projections. For the reconstruction of this $4 \mathrm{~cm}$ height overlapping region, the two groups of 300 projections $(300+300)$ were used simultaneously [53].

Concerning the differences of resolution between conventional CT and dental CBCT, the dental CBCT has a better geometrical resolution than that of the conventional CT $[15,46,49,50,67,71]$. This is the result of the different voxel sizes used in the two techniques. Roughly speaking, the isotropic voxel size for dental CBCT is in the range of 0.076-0.4 mm. In contrast, the conventional CT isotropic voxel value used to be about $0.625 \mathrm{~mm}$ [32] but more recently that value is $0.24 \mathrm{~mm}$ [17].

Needless to say, some of the older conventional CT machines, which may still be in use, operated with non-isotropic voxels, implying that the three coordinates $\mathrm{x}, \mathrm{y}, \mathrm{z}$ were not of the same units. Of historic interest, it may be noted that the very first dental CBCT was such a machine (NewTom QR-9000, Figure 15) [36,41,42].

\subsubsection{Advantages and disadvantages of dental CBCT}

There are different advantages and disadvantages to conventional CT and dental CBCT [11-17,29,32,36,37,43-50,67,70,71,73-75]. 
The advantages of conventional CT include the following:

- Excellent hard and soft tissue contrast.

- Accurate measurements in Hounsfield units are possible, even in the case of soft tissues.

- The FOV can be extended as may be necessary.

- There are fewer artefacts in the reconstructed scan [29].

The disadvantages of conventional CT include the following:

- The radiation dose is 30-50 times higher than dental CBCT.

- The equipment is more expensive.

- The size of the isotropic voxel cube is considerably higher than that of dental CBCT. It is in the range of $0.625-0.24 \mathrm{~mm}$ for conventional CT in contrast to $0.125 \mathrm{~mm}$ for iCAT and 0.076 mm for KODAK/CS 9000 3D.

- Since patients have to lie down in a tube of the conventional CT instrument; they may develop a feeling of claustrophobia.

- The equipment requires a larger room and increased radiation protection.

The advantages of dental CBCT include the following:

- Pathological condition of hard tissues can be viewed in different planes.

- Lower radiation dose than conventional CT.

- Scanning time is very fast.

- In the 3D volume uses isotropic voxels with sub-millimetre resolution.

- Most of the manufacturers provide free viewer software with extended functionality enabling interactive analysis.

- Less expensive than conventional CT.

- It is also possible to export the reconstructed volume in DICOM format.

The disadvantages of dental CBCT include the following:

- During the acquisition, the patient must be absolutely motionless.

- Soft tissues are imaged quantitatively but not qualitatively. Poor soft tissue contrast.

- Higher radiation dose than other dental radiographs.

- Dental CBCT technique is not capable of caries detection [73].

- Over all there are more artefacts in the reconstructed dental CBCT scan than in conventional CT scan [29]. 
- Dental CBCT, just like conventional CT, is sensitive to metallic objects such as fillings and implants. These may produce one class of artefacts, called metal artefacts, but there are fewer at the level of the occlusion by dental CBCT acquisition than in conventional CT $[10,11,15,43,74]$.

- More noise in the dental CBCT image than in conventional CT $[29,36,37,46,48,67,70,71,75]$.

\subsection{Various image artefacts in dental CBCT}

Some distortion or error in the image is regarded as an artefact if this appearance is unrelated to the subject examined $[16,17,29]$.

\subsubsection{Inherent artefacts}

The limitation of physical processes causes the artefacts during acquisition in CBCT data. The following three types of cone beam-related artefacts are recognized:

- Scatter effect;

- Cone beam effect;

- Partial volume averaging effect.

The scatter effect is the result of scattered X-ray photons which are diffracted on matter and change their original path. This image degradation is sometimes called 'quantum noise' (Figure 21 A) $[10,12-17,29,30,36,68]$.
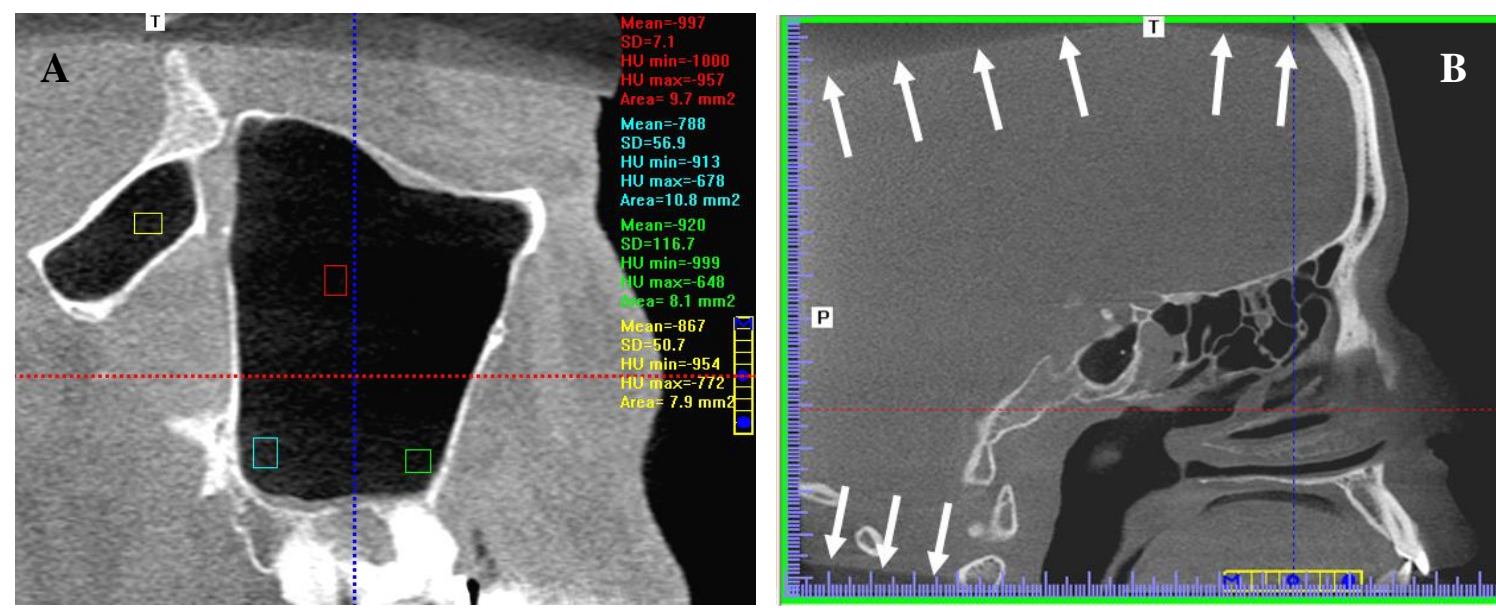

Figure 21 A: The scatter of X-ray photons influence the grey values, measured in HU, in the reconstructed CBCT volume [29,30,32,37,49,50,66]. For instance, according to definition by MDCT, the air HU value is exactly -1000. As may be seen in the dental CBCT image, the measured areas of air are in the range of (-678) (-1000). B: The arrows are showing the cone beam effect in the coronal section of FOV $[16,17,29,32,76]$. 
The cone beam effect artefact occurs particularly frequently at the peripheral area of the scanned volume. The superior and inferior peripheral extension of the volumetric data set of the scanned volume is causing a peripheral ' $\mathrm{V}$ ' artefact at the top and bottom of the FOV (Figure 21 B). This is a visible change of the grey scale in the reconstructed image. It causes an increased noise, as well as distortion and reduced contrast. By appropriately positioning the FOV in the horizontal plane of the X-ray beam, the artefact can be reduced [13,14,16,17,32].

The partial volume averaging artefact occurs when the refinement of the chosen voxel size is larger than the size of the details of the scanned object $[10,13,14,16,17,29,30,62]$. (Figure 22 A, B, C and D). This is also illustrated later in Figure 34.
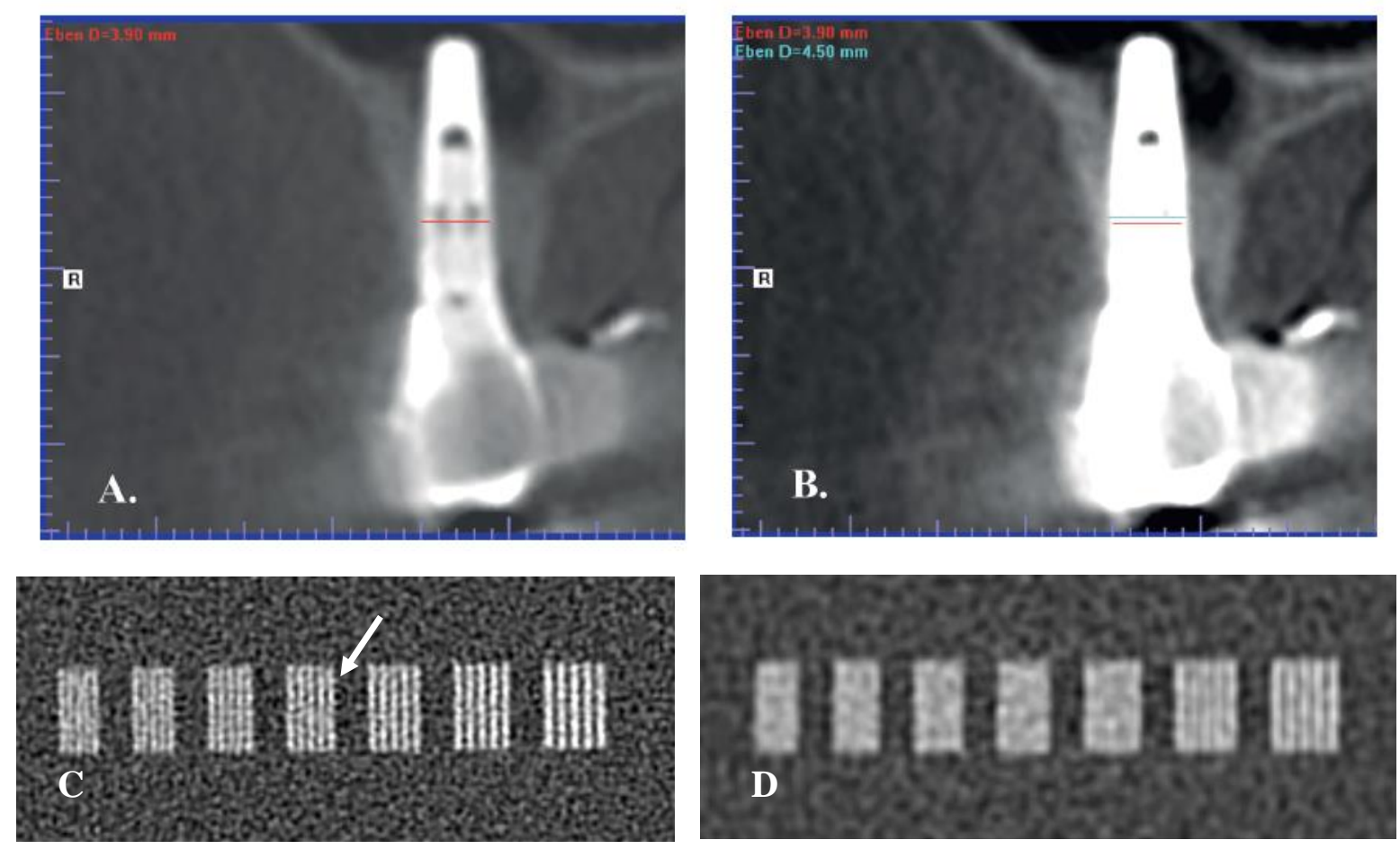

Figure 22 Partial volume averaging artefact. The same oral implant shows two different diameters due to different brightness and contrast adjustment of the images on the same dental CBCT aquisition (A and B). This is caused by the pixel structure of the reconstructed image due to the fact that the voxel on the implant surface can possibly have two different grey values depending upon image brightness and contrast adjustment. Images $\mathbf{A}$ and B: were created by the interpolation of the digital image pixels structures (compare to Figure $34 \mathbf{D}$ ). The same bar pattern phantom was used for two different CBCT acquisitions: C: RD600 02 and D: RD 60004 (compared to the definition given in Table II). Note that in Figure 22 C the ring artefact is also seen (arrow) $[10,13,14,16,17,29,30,62,72]$. 


\subsubsection{Procedure-related artefacts}

These artefacts appear either as fine striations or as lighter or darker concentric circles within the reconstructed image $[16,17]$.

Circular or ring artefact typically appears on an axial image (Figure $23 \mathbf{A}$ and $\mathbf{B}$ ). This is the visual appearance of the imperfections in scanner detection resulting from poor calibration of the detector. It may also be caused by a damaged detector $[13,14,16,17,29,72]$.

This striation, the so-called Moire artefact, could be caused by under-sampling (Figure 23 C, D and E). The under-sampling could be caused by two factors: it may occur when too few 2D basis projections were taken during the acquisition, or when the angle of rotation was insufficient. Both of these factors could cause a noisier and less sharp image with possible striations in the reconstructed volume (Figure $23 \mathbf{C}$ and D) $[10,13,14,16,17,29,36]$.
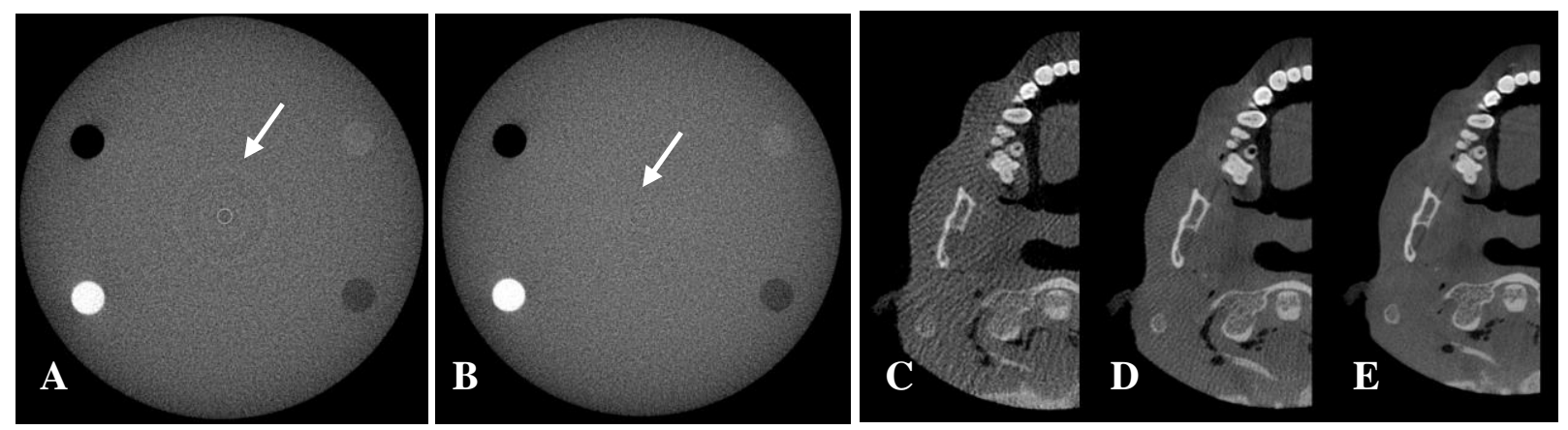

Figure 23 Typical examples for ring artefacts in CBCT image which may result from failures of the calibration process (CP). Reconstructed images of the $150 \mathrm{~mm}$ diameter standard Imaging Sciences International Inc. quality-assurance phantom, which is made of air $\left(1.29 \mathrm{~kg} / \mathrm{m}^{3}=0.00129 \mathrm{~g} / \mathrm{cm}^{3}\right)$, LDPE $\left(0.92 \mathrm{~g} / \mathrm{cm}^{3}\right)$, acryl $(1.18$ $\mathrm{g} / \mathrm{cm}^{3}$ ) and Teflon $\left(2.16 \mathrm{~g} / \mathrm{cm}^{3}\right)$ embedded in a Plexiglas cylinder. In the height of these two axial slices the bar pattern phantom is not visible (compare to the image of the bar pattern phantom in Figure 22 C and Figure 31 B). On both of these acquisitions ring artefacts are detectable (arrows) because these scans was taken without the calibration process of the detector. A: COLD. B: WARM (compare for details Table III). C, D and E: Moire artefact caused by under-sampling. The cadaver head* has been scanned with three different acquisition modes of the same dental CBCT equipment. C: RD150 04. D: RD300 0.4. E: RD600 0.4 [13,14,16,17,29,72].

Properties for these experimental conditions of the applied acquisitions chosen for this study are in Table II and III. The four inserts of the quality assurance phantom are arranged in the following sequence: upper left hand side air, lower left hand side Teflon, lower right hand side LDPE and upper right hand side acryl (A and B). (Window 3000, level 605, applied filtering: 'Sharpen $3 \times 3$ ' by XoranCAT technology acquisition program, version 3.1.62). LDPE, low-density polyethylene.

*Department of Anatomy Histology and Embryology, Semmelweis University, Budapest, Hungary. 


\subsubsection{Introduced artefacts}

This type of artefact is due to the physical characteristic that lower energy photons are absorbed preferably to higher energy photons. This is frequently called beam hardening (Figure 24). Distortion of metallic or dense objects causes such an artefact, called a cupping artefact. It may also show dark streaks when the X-ray is passing through between two dense objects. These may be called extinction or missing value artefacts. These phenomena can also be seen in the case of contrast material filled vessels (Figure 34) $[12,13,14,16,17,29,30,62,76]$.

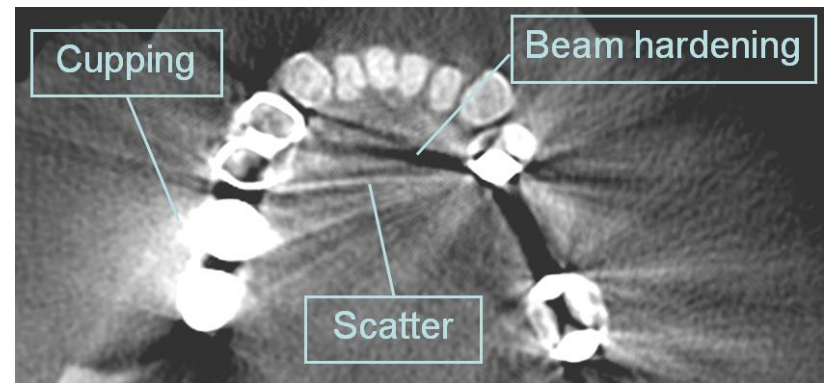

Figure 24 The presence of different artefacts in the FOV: metal artefacts, scatter and beam hardening [16,17,62].

\subsubsection{Patient motion artefacts}

Motion of the patient may result in further artefacts on the reconstructed CBCT image. An indication of patient motion is increased noise and the appearance of double contours in the reconstructed image $[10,12-14,16,17,29,62]$.

\subsection{Quality improvement of images by post-processing methods}

The ultimate goal in dental CBCT imaging, similarly to the applications of all other medical X-ray imaging techniques, is to achieve the best possible image quality with the use of minimal radiation dose $[12,42,77]$. This can be achieved in three phases during work-flow. The first phase and the second is done during preparation and execution of the data collection, and includes the following items:

- well maintained equipment;

- warming-up period (WUP), if it is required [52,54,55,72];

- calibration process $(\mathrm{CP})$, if it is required [52,54,55,72];

- instructions to the patient $[35,73,78]$;

- the precision of the applied scanning geometry [29-31,53,60]; 
- the quality of the reconstruction of the applied software i.e. reconstruction algorithm [12,29-31,53,60].

All of these are regarded as pre-processing or processing components of the work-flow. These will be investigated and discussed, in some details, in this dissertation.

There are also post-processing methods in this field. The highest professional opinion in valuing the post-processing methods is clearly declared by Professor Ralf Schulze at Johannes Guttenberg-University of Mainz, Germany [29]:

'It is no surprise that the technical community puts considerable efforts into developing techniques for artefact reduction. Many of them are post-processing algorithms operating on the $3 D$ volume data. Although this may result in considerable reduction of some apparent artefact structures, from a physical point of view post-processing is like putting the cart before the horse since the error has been integrated into the volume already. Consequently, more modern approaches attempt to avoid reconstruction errors either by supplementing missing or incorrect information in the projection images or by iterative reconstruction process.'

\section{$3 \quad$ Aims}

The purpose of the present dissertation is the examination of the grey value accuracy and the improvement of image quality in dental CBCT. These investigations involved the preprocessing and the processing work-flow in order to minimize the technical limitations and thereby maximize the quality of the reconstructed image. This purpose was motivated in accordance with the as-low-as-reasonably-achievable (ALARA) principle which is a worldrequirement in the $21^{\text {st }}$ century. Consequently, the radiation dose for dental patients should be optimized to achieve the lowest practical level to address a specific clinical situation. For this reason, it is of considerable importance that we obtain the best necessary image quality on a certain radiation level [72,77]. The possibility of achieving the above goals have been examined by investigations summarized in the following three Research Topics:

A minimizing the noise in the reconstructed dental CBCT image;

B reducing the presence of artefacts;

C improving the image quality by obtaining more accurate grey values in the reconstructed image.

The study of these three Research Topics materialised in four scientific publications (Papers 1-4). 
Eight Thesis Points have been established which are related to the three research topics and four papers in the following way:

1 Minimizing the noise in the reconstructed dental CBCT image (Research Topic A). Conditions established by drastic mass reduction in the FOV (Paper 1).

2 Minimizing the noise in the reconstructed dental CBCT image (Research Topic A). Conditions established by calibration of the detector and reaching its steady-state temperature during the warming-up period (Paper 2).

3 Minimizing the noise in the reconstructed dental CBCT image (Research Topic A). Conditions established by using a more accurate reconstruction algorithm (Paper 4).

4 Reducing the presence of artefacts (Research Topic B).

Conditions established by calibration of the detector and reaching its steady-state temperature during the warming-up period (Paper 2).

5 Reducing the presence of artefacts (Research Topic B).

Conditions established by determining and then employing the ideal contrast material concentration during the procedure of mapping of the angiosome (Paper 3).

6 Improving the accuracy of grey values in the reconstructed image (Research Topic C).

Conditions established by drastic mass reduction in the FOV (Paper 1).

7 Improving the accuracy of grey values in the reconstructed image (Research Topic C).

Conditions established by calibration of the detector and reaching its steady-state temperature during the warming-up period (Paper 2).

$\mathbf{8}$ Improving the accuracy of grey values in the reconstructed image (Research Topic C).

Conditions established by using a more accurate reconstruction algorithm (Paper 4).

Consequently, we must realize, as a basic problem, that a reconstructed dental CBCT image doesn't show precisely the facts as they are. 
(i) X-ray scattering causes and increases the noise in the reconstructed image $[37,71]$ therefore it reduce image quality and furthermore it is influencing grey values $[29,30,37,49,50,66,70]$.

(ii) The presence of different artefacts, which are causing a change in the data of the reconstructed image and therefore reduce the fidelity of the density value in the reconstructed image [30,34,37,39,47,49,50,66,79].

(iii) At last but not least, due to the data collection from single circular orbit is insufficient for an accurate reconstruction of the volume using cone beam geometry. Consequently, this leads to the fact that, in general, there is no perfect acquisition procedure in use $[29,31,60]$.

The magnitude of the problem is illustrated by the fact that at least one of the companies makes the following statement at each acquisition:

'Warning, CT data does not accurately represent biological data and therefore caution and sufficient time must be taken for observation' [80].

\section{$4 \quad$ Materials and Methods}

All experiments carried out and summarized in this dissertation involved two classes of instruments, MDCT and dental CBCT; the latter of these included three specific instruments: Vatec Picasso (E-WOO Technology Co., Ltd. (Factory No.2) 139-2, 138-2, Hagai-dong, Giheung-gi, Yongin-si, Gyeonggi-do Korea), iCAT Classic and KaVo 3D eXam (Imaging Sciences International (ISI), Hatfield, PA, USA) as illustrated in Figure 25. The first, MDCT, was manufactured by General Electric (GE) Medical Systems LightSpeed VFX Ultra, Tokyo, Japan.

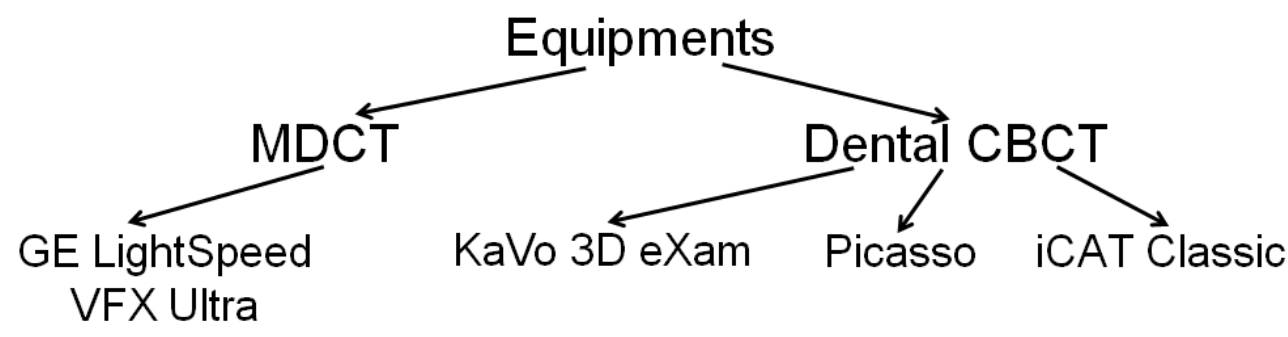

Figure 25 A schematic illustration of the various classes of equipment used in the present research. Note that the MDCT measurements represent a gold standard of this field. 
The following materials were used in these in vitro studies, covered by the three Research Topics and resulted in four papers:

- ISI quality-assurance phantom;

- water phantom;

- mandible phantom with and without spine (specific developed);

- extracted upper premolar tooth of a mummy;

- cadaver heads or block of cadaver heads.

The three factors, which reduced the quality of dental CBCT image, were covered in the three research topics examined. These three Research Topics, which resulted in four published papers, dealt with the details of the pre-processing and processing work-flow as outlined in the Aims (Section 3 on page 24).

Paper 1 This paper appeared as a book chapter [63], discussing Research Topic A and Research Topic $\mathbf{C}$, minimizing the noise caused by X-ray scattering and achieving a better density response. In this case, Picasso Pro dental CBCT equipment was used (E-WOO Technology Co., Ltd. (Factory No.2) 139-2, 138-2, Hagai-dong, Giheung-gi, Yongin-si, Gyeonggi-do Korea). The examined material was an extracted upper premolar tooth of a mummy. A reduction of X-ray scattering is resulted in this in vitro study. This was due to reduction of the mass and size of material in the FOV, as the scan was taken only of this single tooth without the head. Thus, it was possible to arrive at a better image quality. In accordance to section Aims on page 24; in essence this reduction of X-ray scattering caused the reduction of the noise in the reconstructed image (Research Topic A). Therefore these changes increased the contrast resolution and yielded a better density response (Research Topic C) of the dental CBCT instrument [13,16,17,29,30,36,37,39,46-50,53,66,69,71]. This work has been based on an X-ray scattering study using iCAT Classic and KaVo 3D eXam equipment [81].

Paper 2 In this publication [72], discussing Research Topic A, Research Topic B and Research Topic C, iCAT dental CBCT and GE MDCT instruments were utilized. The purpose of these experiments were to minimize the noise and artefacts, and furthermore, to improve the accuracy of grey values in the reconstructed image. Note that the MDCT measurements represent a gold standard in this field. To investigate the effect of the detector 
temperature and that of the calibration process of the flat panel detector (FPD) on the dental CBCT image quality, four different experimental conditions were used (Table III).

Table III List and abbreviations of the four experimental conditions used for the flat panel detector (FPD) in the present study [72].

\begin{tabular}{|l|l|}
\hline cold detector without calibration: COLD & cold detector with calibration: COLD+C \\
\hline warm detector without calibration: WARM & warm detector with calibration: WARM+C \\
\hline
\end{tabular}

COLD means the acquisition was taken without warming-up period and calibration process of the FPD.

$\mathrm{COLD}+\mathrm{C}$ is the abbreviation for the scan taken directly after the start of the equipment with cold detector but after the calibration process. The WARM operation mode indicates that the machine was on for at least two hours before the scan but no detector calibration was performed. The WARM+C scan protocol is consistent with the cone beam computed tomography scan with the complete calibration sequence after the warming-up period. The two-hour warming-up period preceded the calibration process.

First, the measured grey values in Hounsfield units (HU) were compared for the four different experimental conditions of the four homogenous density materials of ISI qualityassurance CBCT phantom: air $\left(1.29 \mathrm{~kg} / \mathrm{m}^{3}=0.00129 \mathrm{~g} / \mathrm{cm}^{3}\right)$, low-density polyethylene (LDPE) $\left(0.92 \mathrm{~g} / \mathrm{cm}^{3}\right)$, acryl $\left(1.18 \mathrm{~g} / \mathrm{cm}^{3}\right)$ and Teflon $\left(2.16 \mathrm{~g} / \mathrm{cm}^{3}\right)$ [52-55,72,76].

Second, for checking the spatial accuracy of the CBCT images in the four applied scan conditions, the visibility of the bar pattern at the centre of the ISI quality-assurance phantom was investigated [52,72].

Paper 3 The scientific basis of this paper [82] was presented previously as two separate congress lectures $[83,84]$, discussing the use of iCAT Classic CBCT equipment. The goal of the first congress lecture [83] was to find a protocol and ideal contrast material concentration for the different mass size in the FOV using dental CBCT. The second congress lecture included the anatomical study of the intraosseous vascular territory (angiosomes [85]) of the facial artery. In this examination [82,84], cadaver heads or block of cadaver heads were used. With an established procedure it was possible to minimize the presence of artefacts (Research Topic B). For this reason a special calibration process was developed by varying different contrast material concentrations in order to achieve the maximal visibility of the contrast material filled vessels in soft tissues and bone. It was also necessary to create a special phantom to model both for the cadaver heads and the blocks instead of performing a real anatomical examination. For this preliminary study [83], contrast material filled plastic 
tubes were used in these phantoms during the dental CBCT acquisitions. The advantage of using these phantoms was the possibility to make several series of measurements using different concentrations of various types of contrast materials. These dental CBCT examinations were also reproducible with these phantoms [83]. On the basis of this preliminary study [83] a predetermined concentration of the Microtrast contrast material solution (Microtrast, Guerbet GmbH, Sulzbach, Germany) was used in the anatomical study of filled vessels [84] as outlined in Paper 3 [82].

Paper 4 In this paper [53], discussing Research Topic A and Research Topic C, the same instruments were used as in Paper 2. The MDCT measurements represented the gold standard as in Paper 2. This in vitro study was performed using both an ISI quality-assurance phantom and a water phantom; the former of these was used in Paper 2. These experiments were performed using also the concept of sequential cone beam computed tomography (SCBCT) $[13,60]$, to obtain dental CBCT imaging with more realistic grey values (apparent density (AD)) and reduced noise. This yielded in lower SD values, as compared with other scan modes using the same iCAT Classic dental CBCT. According to the literature $[37,65,69]$, dental CBCT technology using Feldkamp algorithm or its modifications, can lead to visualization of the high-contrast structure in the acquisition, similar to MDCT for the "bone window" range. Therefore those phantoms, which are containing lower-density materials inserts such as fine trabecular bone, D4 (corresponding to acryl) [30], or soft tissues that are mimicked by LDPE cannot be studied quantitatively using Feldkamp algorithm [37,42,53,72]. In contrast to this, using the same dental CBCT equipment, all four inserts in this ISI quality assurance phantom will give more accurate grey value and lower SD value applying the SCBCT concept rather than Feldkamp algorithm. These experiments were designed to obtain a definite proof, that the SCBCT method gives better image quality. This point made it essential that the ISI quality-assurance phantom is used in this investigation presented in

\section{Paper 4}

\section{$5 \quad$ Results and Discussion}

\subsection{Focusing on X-ray scattering as the first basic problem}

Scattering may be a significant problem in all radiation phenomena. Clearly, X-ray is no exception. The quality of all X-ray images is reduced by the extent of the magnitude of scattering [13,14,29,30,37,49,50,66,70,71]. In dental and maxillo-facial CBCT imaging, 
scattering could be so intense, with respect to the direct radiation, that it could produce ghost pictures of the non-radiated region of the skull [81].

In this section, two studies are discussed. In the first study the magnitude of scattering was determined with respect to the magnitude of direct and forward scattered radiation [81]. In the second study a singular premolar tooth was subjected to complete X-ray imaging investigation by dental CBCT technology [63]. In that case, the detailed mapping and reconstruction of the shape of the dry soft tissue within the internal cavity of the tooth was possible because there was opportunity for the drastic reduction of scattering. This became possible because there was no solid surrounding around this single tooth. Consequently, the mass encountered by the X-ray beam does influence both the noise and the grey value accuracy (in HU) [37,47,76]. Of course the image quality is also dependent on the accuracy of the measured grey value in HU. The question: how could be maximise the quality of the reconstructed image without the drastic reduction of the mass in the FOV will be discussed in

\section{Section 5.2.}

\subsubsection{Examination of the magnitude of X-ray scattering on CBCT imaging}

In order to minimize the radiation dose, it is desirable to reduce the size of the FOV. This could be achieved either by reducing the height or the diameter of the FOV. It is possible to vary the height of the FOV using the $\mathrm{KaVo} 3 \mathrm{D}$ eXam dental CBCT equipment during the continuous setting of the direct beam size by the adjustable beam gate (Figure 26 A) [54].

In the lower part of Figure $26 \mathbf{~ B}$, the lower jaw is shown with a $57 \mathrm{~mm}$ height FOV. Even though the beam gate allowed a $57 \mathrm{~mm}$ radiation, nevertheless the detector recorded the total of the $130 \mathrm{~mm}$ height FOV. Consequently, it was possible to reconstruct the full $130 \mathrm{~mm}$ height FOV using the original raw data (RD). This is shown in the upper part of Figure $26 \mathbf{B}$. It should be emphasized that this figure consists of two parts. The lower part of the image has diagnostic value and the upper part shows the 'ghost picture' of the higher part of the face. Clearly, this ghost picture is due to the scattering of the X-ray as it was not exposed to direct radiation due to the beam gate position (Figure 26 C) [81]. In order to exclude an error of the equipment, originated from the possibility that the door of the beam gate would not be blocked completely for the X-ray radiation, the opened part of the beam gate was covered with a lead plate. Air KERMA measurement was obtained with radiation measurement equipment (Radcal Corporation model 9015). Under this experimental condition no X-ray radiation was detectable [81]. Consequently, the experiment determined the magnitude of the 
scattered and direct radiation as well as their ratio, using thermoluminescent dosimeters (TLD) [86]. Therefore a scan was taken from each of the researchers with the indication to investigate the position of their lower wisdom tooth (RD600 04). The measured values are shown by the height of the individual columns in Figure 26 D [81]. In addition, the TLD was placed directly to the neck skin by way of the direct beam, and the value of the absorbed radiation was $4 \mathrm{mGy}$. On the internal and external side of the leaded apron, TLD doesn't show anything [81]. On the basis of the above, it was clear that this phenomenon was produced only by scattered radiation, and we have shown that, in the reconstructed image, not only the direct beam but the scattered radiation plays a major role. The sensor is not to discriminate between the signals from the direct and the scattered radiation. The absorbed radiation by the detector from the scatter not only increased the noise in the image but it is also influenced the accuracy of the grey value $[13,16,17,29,30,36,37,39,47-50,53,66,69,70,81]$.

A

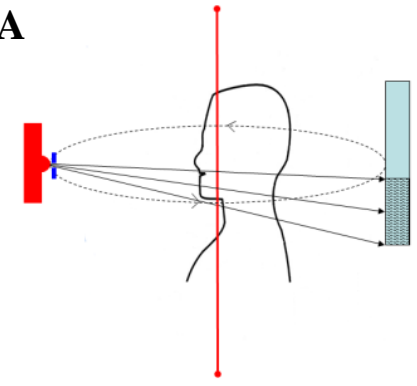

C

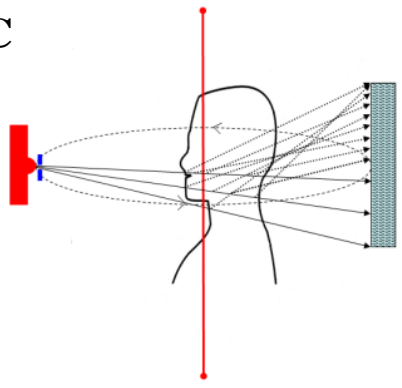

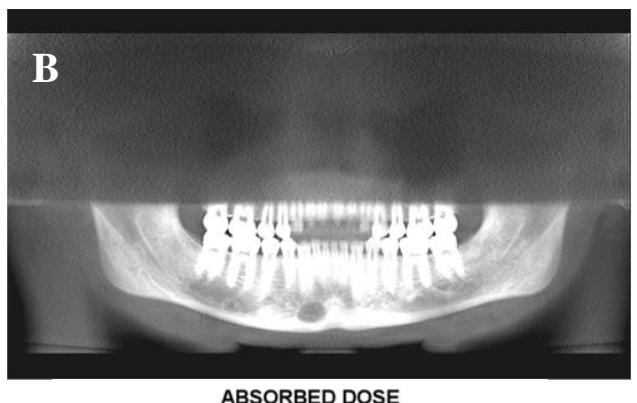

ABSORBED DOSE

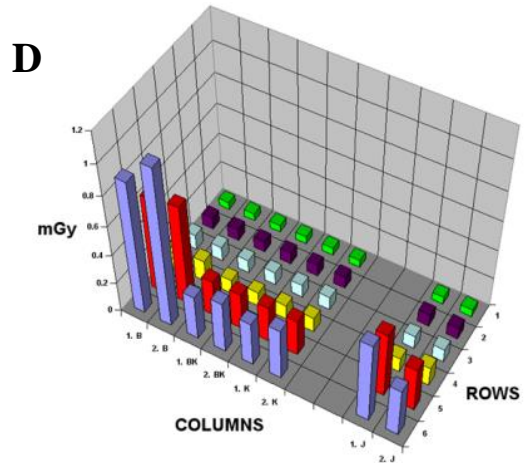

Figure 26 The height of FOV can be adjusted by the setting of the beam gate [54]. A: Only the lower part of the detector exposed to direct radiation for the acquisition of the lower jaw since this is what is permitted by the beam gate. In this way the dose of CBCT exposure to the patient can be minimized. B: In this case, the detector pictures, the so-called raw data (RD) images, were used in the reconstruction, and their heights were extended from 57 to $130 \mathrm{~mm}$ height. Consequently, the original $57 \mathrm{~mm}$ height FOV acquisition was reconstructed in 130 $\mathrm{mm}$. All of this was done without any new exposure. Above the original $57 \mathrm{~mm}$ height FOV (lower jaw), new recognizable anatomy structures of the skull became recognizable in the whole volume of the image. The observation of such 'ghost pictures' was possible, in all similar cases, in a reproducible fashion. C: This schematic illustration shows the scattering of the X-ray photons which is the origin of the 'ghost pictures' 
phenomenon. D: This plot shows the distribution of the radiation dose on the detector surface during the applied lower jaw acquisition. Rows 1 to 4 are associated with the 'ghost image' caused by the scattering of the radiation. Rows 5 to 6 are the region of the opened beam gate. A total of 30 pieces of LiF (type: MTS-N) thermoluminescent dosimeters (TLD) were used for this investigation [86]. The dose distribution measurements on the sheet during the $20 \mathrm{sec}$ exposure were performed (by $4 \times 6=24$ pieces) in four columns six rows of TLDs. It was supposed that during the scan (360 degree rotation) the dose distribution would be symmetrical; hence, the fifth column TLDs were not required. The values of the absorbed doses in the grid (in booth examinations) were increasing toward the left lower corner, and the distribution was not symmetric. The range of the direct and forward scattered radiation was less than 9 and 30 percent [81].

\subsubsection{Examination of the possibility of mapping of dry soft tissue within a single tooth} with the drastic reduction of $\mathrm{X}$-ray scattering

From the previous chapter as well as from earlier literature $[13,14,16,17,29,30,36,37,39,47-50,66,69-71]$, it became clear that the scattering phenomenon represents a major problem in the $\mathrm{CBCT}$ imaging technique. With increasing mass and size of material in the FOV, internally, as well as externally (exomass effect), there is an increasing magnitude of X-ray scattering accompanied with increasing noise. These factors also influence the accuracy of the grey values in the reconstructed image $[37,39,47,66,68,71,75,76]$. Therefore the internal soft tissue in a tooth is not very visible when the tooth is in the head. Consequently, a better picture is expected in the case of a single tooth. The following case study illustrates this clearly.

The high priest, Pál Szechenyi (1642-1710), died under dubious circumstances. According to rumours he was poisoned by arsenic. The examination of the internal structure of an upper premolar tooth is expected to show if there is any arsenic content or not. Figure 27 shows the Reverend Pál Szechenyi and his investigated tooth [63].
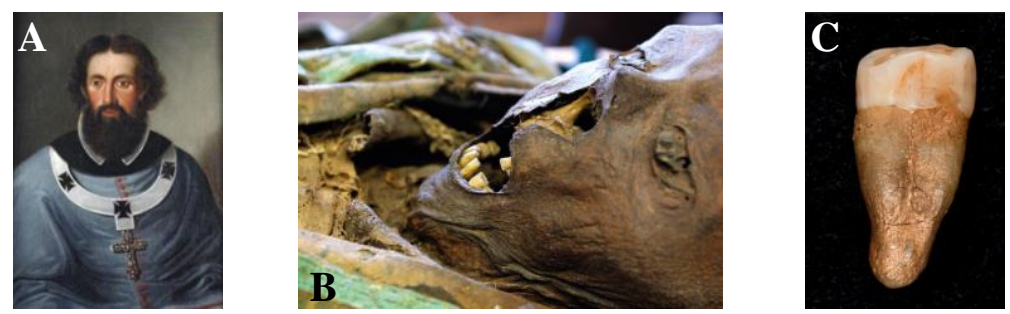

Figure 27 A: The painted portrait of the living high priest. B is the photograph of the dead mummy of Reverend Pál Szechenyi. C: shows the photographs of the investigated upper premolar tooth [63].

The applied dental CBCT technique allowed the generation of the X-ray image of the tooth, as well the selected cross-section image. Consequently, it was possible to take only one 
X-ray, a dental CBCT acquisition, to create all the needed X-ray images [63]. These are shown in Figure 28 as well as Figure 29 B and C.
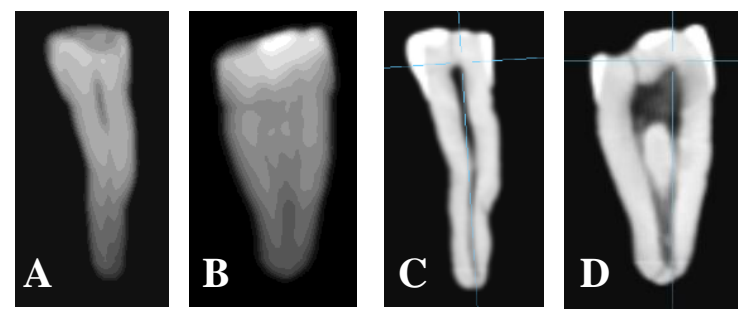

Figure 28 Views of ray sum [17] images ( $\mathbf{A}$ and $\mathbf{B}$ ), like images of conventional 2D dental X-ray, and the selected cross section images $(\mathbf{C}$ and $\mathbf{D})$ of the investigated tooth. These are generated from the 3D database of the dental CBCT acquisition by the software called 'EzImplant Dental3D viewer' [63].

The dried residue of the soft tissue of the pulp is shown in images $\mathbf{A}$ and $\mathbf{C}$ in Figure 29. It is this that is expected to contain arsenic in the case of poisoning. Subsequent examination showed no arsenic content; therefore, the priest died of natural causes [63].
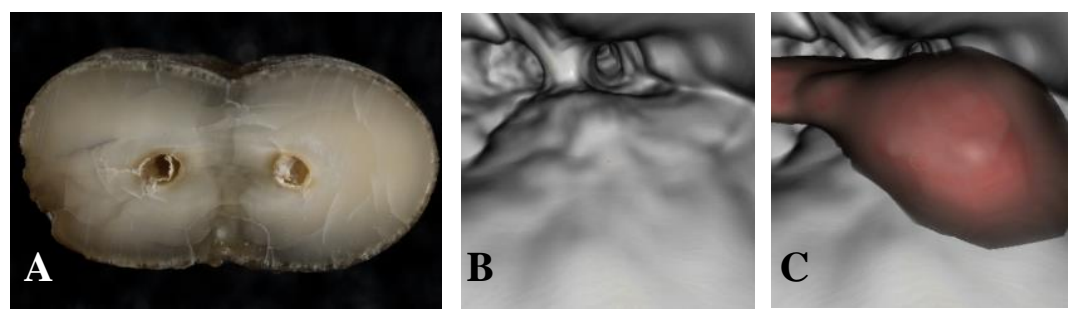

Figure 29 Image $\mathbf{A}$ is the photograph of the investigated tooth after slicing. The two arrows show in the cross section of this tooth the dry soft tissue in the two root canals. Images $\mathbf{B}$ and $\mathbf{C}$ are generated from the $3 \mathrm{D}$ database of the $0.2 \mathrm{~mm}$ resolution dental CBCT acquisition of the whole tooth. B: This image shows the 3D reconstruction of the inner surface of the root canal and pulp chamber of the investigated tooth. C: Dental CBCT image which also shows the dried residue of the soft tissue of the pulp in the canal and in the pulp chamber. Figures $\mathbf{B}$ and $\mathbf{C}$ were generated by the software called 'EzImplant Dental3D viewer' [63].

It should be emphasized that reduced X-ray scattering occurring in the case of a single tooth made it possible to make the internal soft tissue of the tooth observable by dental CBCT-technique (Figure 29 C). Applying this reduction of the mass and size of material in the FOV, using the reduction of X-ray scattering, it was possible to arrive at a better image quality. This decrease of X-ray scattering causes the reduction of noise in the reconstructed image; therefore it causes an increase in contrast resolution and leads to a better density response of the dental CBCT instrument $[13,16,17,29,30,36,37,39,46-50,53,66,69,70,71]$. The advantage of the method outlined about has shown that it was possible to examine of the inner soft tissue content before the destruction of the single tooth structure [63]. 


\subsection{Optimal density response for the dental CBCT imaging as the second basic} problem; quality improvement by pre-processing and processing workflow

Cone beam computed tomography (CBCT) was originally developed in the early 1980s for angiography $[16,17,36,41,53,69]$, and more than a decade later it was applied to dentomaxillofacial diagnostics. The main advantages of CBCT are relatively high-resolution acquisition and, compared with conventional CT, lower radiation doses with smaller and less expensive equipment $[12,16,17,36,44-49,53,69,70,79]$.

As was discussed in Section 5.1, from a technical point of view, the limitation of image quality by dental CBCT technology is dependent on the increased X-ray scatter. This not only increases patient dose but also is a principal contributor to reduced contrast resolution and increased noise in CBCT images [37,46,53,69,71], therefore influencing the density values $[13,16,17,29,30,36,37,39,47-50,53,66,69,70]$.

The purpose of the second part of this research was to maximize the accuracy of the measured grey values in $\mathrm{HU}$ and therefore the quality of the reconstructed image without the drastic reduction of the mass in the FOV. The following three sections will show what may be done to achieve that by the given dental CBCT instrument.

- The first section (Paper 2), using the pre-processing workflow, is the optimization of the functioning of the detector [72]. (Section 5.2.1)

- The second possibility (Paper 3) is to establish the applied contrast material concentration [82], appropriate to the characteristics of the applied dental CBCT equipment, in order to reduce the presence of artefacts in the reconstructed image. (Section 5.2.2)

- The third alternative way (Paper 4) involves the change of the applied scanning geometry and reconstruction algorithm to yield a more accurate method [53]. (Section 5.2.3)

\subsubsection{Steady-state temperature and the calibration of the FPD as the result of the pre- processing work-flow}

The image quality of the reconstructed dental CBCT acquisition is strongly dependent on the characteristics of the applied detector. Some flat panel detector (FPD) types require a warming-up period (WUP) to achieve a steady-state temperature; and some of them, those that have a cesium iodide detector, may require a calibration process (CP) after each WUP. To investigate the effect of the detector temperature and that of the calibration process of the FPD on the CBCT image quality, four different experimental conditions were used (Table III) [72]. 
The cone beam computed tomography (CBCT) imaging process consists of several steps (Figure 30) [72].

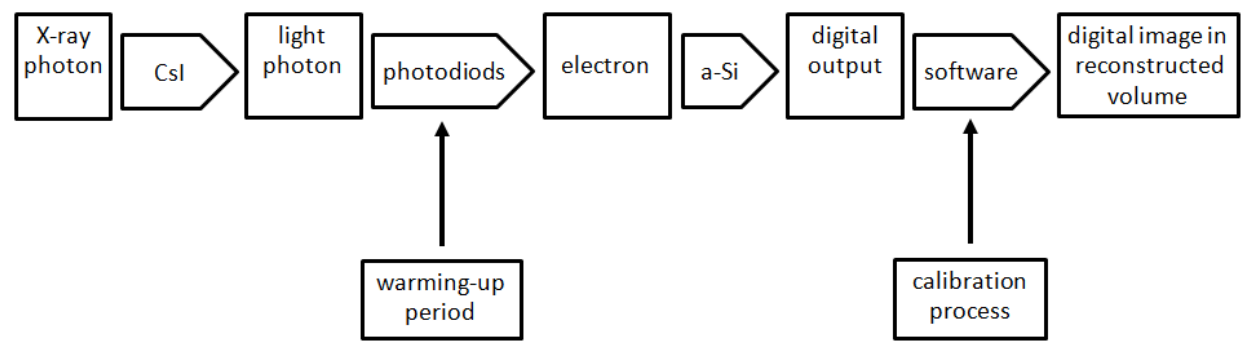

Figure 30 Schematic figure of the signal conversion chain from X-ray to three-dimensional reconstructed image of the dental CBCT equipment, which incorporates an amorphous silicon image detector with a cesium iodide conversion layer [72]. a-Si is the abbreviation for amorphous silicon; CsI means caesium iodide.

The quality of the image may be influenced by a number of effects during the signal conversion chain. One of these is the optimal or non-optimal state of the detector. For example, some instruments which use a certain type of FPD may require a WUP for the detector to reach its steady-state temperature. Also, in certain cases, calibration process of the FPD is recommended for obtaining the ideal image quality. This information may escape the attention of some owners. Also, in an emergency within an oral surgery department, an acquisition must be taken immediately after the start of the equipment. Consequently, it is of utmost importance to investigate the impact of the WUP and the CP of the FPD on image quality, and this was one of the aims of this dissertation. For instance, by iCAT Classic equipment (Imaging Sciences International (ISI), Hatfield, PA, United States) the WUP is about two hours from cold state [52]. After the WUP, an electric fan prevents overheating and maintains a steady-state temperature of $30^{\circ} \mathrm{C}$ in the FPD. The detector system is analysed during the CP and suitable correction data is derived, which is used later in subsequent image acquisition to compensate known deviations from ideal detector behaviour (Figure 30). This modified data would serve as the database for the reconstructed volume of the image $[16,17,72]$.

The objective in the present in vitro study is to investigate the measured grey values and the spatial accuracy of a quality-assurance phantom on the reconstructed image, which is recommended by the manufacturer for quality assessment of the equipment [52]. Figure 31 shows the applied set-up of the quality-assurance phantom in the iCAT Classic dental CBCT equipment, as well as the separate phantom $[52,53,72]$. 


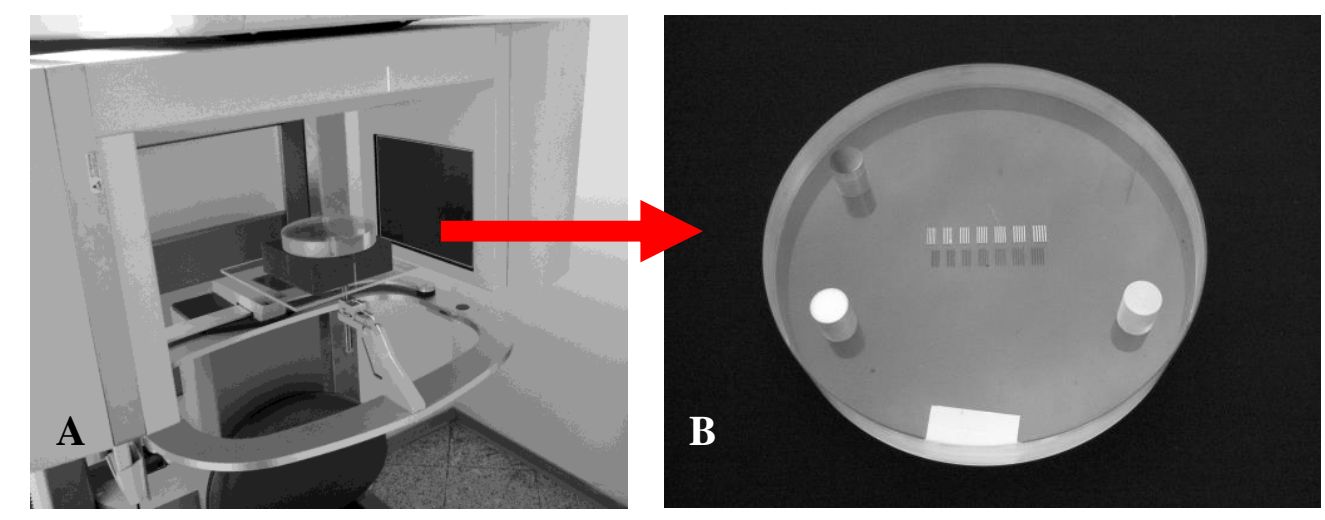

Figure 31 A: Photograph of the configuration set-up of the cylindrical (150 mm diameter) standard Imaging Sciences International (ISI) quality-assurance cone beam computed tomography (CBCT) phantom in the iCAT Classic equipment. B: Photograph of the same ISI quality assurance CBCT phantom $[53,72]$.

The caesium iodide solid-state amorphous silicon FPD is an indirect, two-step X-ray conversion system $[16,17,69,72,87,88]$. This two-step detection is based on the electronic signal generation from the X-ray photons which are not absorbed by the target. The first step is the conversion of the X-ray to visible light. When X-ray photons strike the scintillator screen of the FPD, visible photons are emitted from the incorporated cesium iodide substrate. In the next step of the signal conversation chain, this visible light is converted by the pin photodiodes to electric charge $[69,88]$, which is collected by the integrating amplifier and converted to output signal voltage, leading to digital data (Figure 30) [87]. The resistancecharacteristic of each of the photodiodes of the FPD depends on the temperature; this is why it is important to reach the steady-state temperature of the FPD during the WUP. The other important factor is the calibration process. Consequently, homogeneous X-ray illumination, without any objects interfering with this radiation, is best for testing the detector and finding the pixel defects showing different grey shades. This CP of the iCAT Classic dental CBCT equipment is performed in four steps: 1 . analysing the detector panel; 2. offset calibration; 3 . gain calibration; 4. high gain calibration [72].

Two types of iCAT Classic equipment operation require WUP. One is a 5-second-long WUP of the X-ray tube, which is needed to ensure homogeneous radiation during gain and high-gain calibration. These last two steps of the CP always start with this 5-second exposure without X-ray detection to ensure the warming up of the X-ray tube [52]. Following this period, the gain and high gain calibration is performed with homogeneous radiation, which is necessary to achieve uniform illumination to every pixel of the FPD. The other of the two types is the WUP of the iCAT Classic equipment, the WUP of the FPD, which lasts for two 
hours. This process has been outlined in some detail in a paper [72]. The output electric charge of the photodiodes in the FDP can fluctuate even in the case of uniform photon density. This fixed pattern noise would affect the density response quality of the FPD. Although the X-ray radiation is homogeneous and the FDP has reached the steady-state temperature, some pixels of the FPD will still show different shades. These would appear as lighter or darker ring artefacts [29] around the axis of the rotation on the reconstructed image. The ring shape is due to the rotating motion of the detector during the acquisition (Figure 22 C, Figure 23 A and B) [72]. To prevent such a variable density response, the steady-state temperature of the FDP is not enough. The above-mentioned four-step CP is also required that guarantees the optimal dose response of FPD pixels. The information gathered in this way would be used during the reconstruction process to compensate the differences in photodiode output (Figure 30) [17,72].

Small changes in grey values of the four inserts of the ISI quality-assurance phantom can be detected on the reconstructed CBCT image with the use or the neglect of appropriate $\mathrm{CP}$ and with the alteration of detector temperature. The measured grey values of the four inserts within the ISI quality-assurance Plexiglas phantom are listed in Table IV. The averages and their SD values are shown in the last two lines of the same table (Table IV). The four experimental conditions resulted in four different patterns as shown by the four curves in Figure 32, in which the X-axis represents the expected CT numbers (in HU) as summarized in Table V [72].

Table IV. The measured and mean grey values in Hounsfield units (HU) and the calculated standard deviations (SD) of the four different experimental conditions of the four different materials of the Imaging Sciences International Inc. quality-assurance phantom. Properties for these four applied acquisition protocols chosen for our study are listed in Table III [72].

\begin{tabular}{|c|c|c|c|c|c|c|c|c|c|c|c|c|c|c|c|c|}
\hline & \multicolumn{4}{|c|}{ Air } & \multicolumn{4}{|c|}{ LDPE } & \multicolumn{4}{|c|}{ Acryl } & \multicolumn{4}{|c|}{ Teflon } \\
\hline & COLD & COLD $+\mathrm{C}$ & WARM & WARM+C & COLD & COLD $+\mathrm{C}$ & WARM & WARM+C & COLD & $\mathrm{COLD}+\mathrm{C}$ & WARM & WARM+C & COLD & $\mathrm{COLD}+\mathrm{C}$ & WARM & WARM+C \\
\hline 1. & -999 & -1000 & -999 & -1000 & -326 & -320 & -349 & -324 & -81 & -66 & -80 & -80 & 794 & 870 & 819 & 890 \\
\hline 2. & -999 & -999 & -1000 & -1000 & -346 & -321 & -327 & -328 & -107 & -70 & -68 & -67 & 785 & 868 & 795 & 859 \\
\hline 3. & -999 & -1000 & -1000 & -1000 & -346 & -322 & -336 & -323 & -103 & -63 & -66 & -90 & 760 & 865 & 791 & 886 \\
\hline 4. & -1000 & -1000 & -1000 & -1000 & -343 & -318 & -333 & -328 & -99 & -65 & -95 & -79 & 758 & 886 & 802 & 877 \\
\hline 5. & -999 & $\begin{array}{l}-999 \\
\end{array}$ & -999 & -1000 & -337 & -325 & -337 & -335 & -88 & -64 & -85 & -75 & 768 & 838 & 843 & 859 \\
\hline 6. & -999 & -1000 & -999 & -1000 & -338 & -327 & -327 & -330 & -112 & -67 & -71 & -71 & 796 & 830 & 809 & 862 \\
\hline 7. & -999 & -1000 & -1000 & -1000 & -337 & -323 & -333 & -335 & -94 & -65 & -72 & -68 & 714 & 807 & 814 & 868 \\
\hline 8. & -999 & -1000 & -999 & -1000 & -333 & -330 & -335 & -332 & -95 & -85 & -76 & -79 & 719 & 870 & 819 & 870 \\
\hline 9. & -1000 & -1000 & -1000 & -1000 & -331 & -328 & -327 & -329 & -99 & -68 & -75 & -74 & 721 & 860 & 824 & 880 \\
\hline 10. & -999 & -1000 & -1000 & -1000 & -325 & -316 & -345 & -338 & -85 & -60 & -79 & -77 & 731 & 872 & 807 & 881 \\
\hline Mean & -999.2 & -999.8 & -999.6 & -1000 & -336.2 & -323 & -334.9 & -330.2 & -99.4 & -67.3 & -76.7 & -76 & 754.6 & 856.6 & 812.3 & 873.2 \\
\hline SD & 0,421 & 0,421 & 0,516 & 0* & 7,524 & 4,266 & 7,460 & 4,848 & 9,764 & 6,799 & 8,615 & 6,371 & 31,644 & 24,005 & 15,166 & 11,223 \\
\hline
\end{tabular}

LDPE, low-density polyethylene. *SD values cannot be determined, owing to saturation. 
Table V. The expected computed tomography (CT) numbers in Hounsfield units of four different phantom materials used as independent variable in Figure 32 [53,72].

\begin{tabular}{|l|l|}
\hline & MDCT [53] \\
\hline Air & -999.24 \\
\hline LDPE & -104.10 \\
\hline Acryl & 115.16 \\
\hline Teflon & 965.94 \\
\hline
\end{tabular}

It should be emphasized that in the case of WARM+C condition the deviation from the expected CT numbers (in HU) and the measured grey values (in HU) differ the least in the case of air and Teflon material, of which the latter is of similar density to cortical bone (Table VI). In contrast to the above, in the case of soft tissue equivalent density inserts like LDPE and the spongious bone equivalent density insert like acryl, the cold sensor has given more accurate results but only with calibration $(\mathrm{COLD}+\mathrm{C})$. However, this observation is not contradictory, since dental CBCT technology can enable visualization of the high-contrast structure in the acquisition, similar to MDCT for the 'bone window' range $[11,37,39,43,65,69]$. The numerical data of the Teflon insert indicate that the WUP and subsequently the $\mathrm{CP}$ are absolutely necessary for higher-density objects. According to the literature [37,65,69], CBCT technology is designed for relatively higher-density materials; therefore, lower-density materials such as fine trabecular bone, D4 [30] (corresponding to acryl), or soft tissues that are mimicked by LDPE cannot be studied quantitatively by this method while using this equipment $[37,42,53,72]$. Air, the single insert material, has shown more accurate mean values (WARM+C, WARM and COLD+C) than by MDCT value (999.24 HU). Furthermore, each of the ten measured grey values for the air insert were uniform $(-1000 \mathrm{HU})$ in the case of the applied WARM+C experimental condition [72].

Table VI. Mean grey values (Y). Quadratic regression was used to establish the relationship between the measured grey values (Y) and expected computed tomography (CT) numbers (Table V) of the four inserts: $\mathrm{Y}=\mathrm{AX}+\mathrm{BX}^{2}+\mathrm{C}$ where both $\mathrm{X}$ and $\mathrm{Y}$ are measured in Hounsfield units [53,72].

\begin{tabular}{|l|c|c|c|c|l|}
\hline & COLD & COLD+C & WARM & WARM+C & MDCT [53] \\
\hline Air & -999.2 & -999.8 & -999.6 & -1000 & -999.24 \\
\hline Acryl & -99.4 & -67.3 & -76.7 & -76 & 115.16 \\
\hline LDPE & -336.2 & -323 & -334.9 & -330.2 & -104.10 \\
\hline Teflon & 754.6 & 856.6 & 812.3 & 873.2 & 965.94 \\
\hline
\end{tabular}

Properties for applied acquisition protocols chosen for this study are in Table III. MDCT, multidetector computed tomography; LDPE, low-density polyethylene. 
During the analysis of the spatial accuracy in the CBCT images of the four applied scan conditions, there was no difference observed in the visibility at the line par centre. There was only one curious discrepancy in COLD operation mode. This involves projection of the concentric circles of ring artefacts on the bar pattern phantom, shown by white arrow in Figure 22 C, but it did not influence the resolution of the image [72].

Table VII. Coefficients (A, B and C) of the fitted quadratic equation for the four experimental conditions of the acquisition protocol [72].

\begin{tabular}{|l|l|l|l|}
\hline Code & A & B & C \\
\hline COLD & 0.899 & $1.212 .10^{-4}$ & -224.33 \\
\hline COLD+C & 0.952 & $1.519 .10^{-4}$ & -202.37 \\
\hline WARM & 0.930 & $1.395 .10^{-4}$ & -212.76 \\
\hline WARM+C & 0.961 & $1.691 .10^{-4}$ & -210.56 \\
\hline
\end{tabular}

Quadratic regression was used to establish the relationship between the measured grey values (Y) and expected computed tomography $(\mathrm{CT})$ numbers $(\mathrm{X})$ of the four inserts: $\mathrm{Y}=\mathrm{AX}+\mathrm{BX}^{2}+\mathrm{C}$ where both $\mathrm{X}$ and $\mathrm{Y}$ measured in Hounsfield units.

(Properties for applied acquisition protocols chosen for this study are in Table III.)

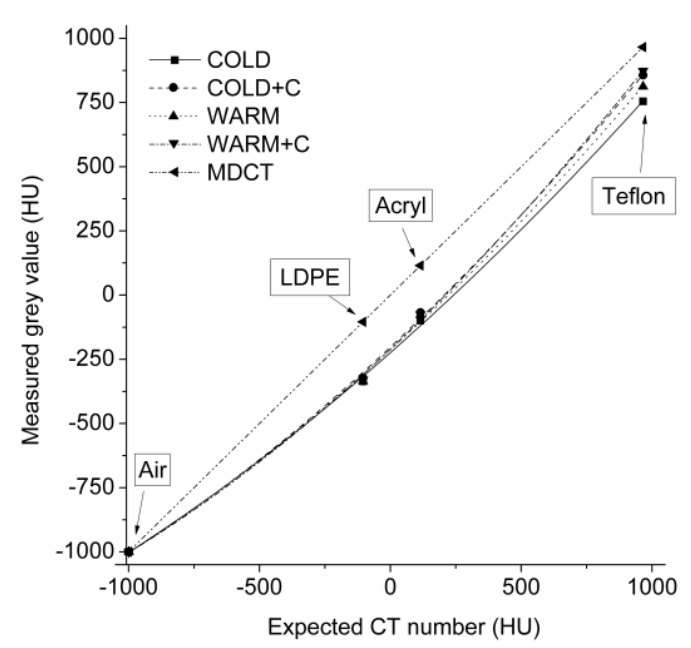

Figure 32 The $45^{\circ}$ straight line corresponds to perfect correlation, which is $\mathrm{Y}=\mathrm{X}$, where both variables are the MDCT values (expected CT number in HU). Fitted quadratic equations of the four inserts of the quality assurance phantom are for the four experimental conditions of the acquisition protocol. The measured grey values correlated with the multidetector computed tomography (MDCT) expected Hounsfield unit (HU) values slightly parabolically, and in the case of Teflon almost reached the perfect correlation (defined by the $45^{\circ}$ line).

Fitting parameters are summarized in Table VII. The measured data are listed in Table VI. The expected computed tomography (CT) numbers in Hounsfield units are given in Table $\mathbf{V}$ [72].

(LDPE, low-density polyethylene; MDCT, multidetector computed tomography; HU, Hounsfield units.) 
In summary, one may say that the use of higher density homogeneous insert materials, such as Teflon, in the quality-assurance phantom yields proof for the need of WUP and after the WUP the CP in certain types of FPD. The data obtained by air insert has also supported this observation because the value $(-1000 \mathrm{HU})$, set by the definition, was reached gradually during the $\mathrm{COLD} \rightarrow \mathrm{WARM} \rightarrow \mathrm{COLD}+\mathrm{C} \rightarrow \mathrm{WARM}+\mathrm{C}$ experiment conditions. In contrast to this, lower density homogeneous materials than Teflon, such as acryl and LDPE, do not mimic the density range of compact bone; therefore, they are not ideal to investigate the density response of this dental CBCT (Figure 32). Furthermore, it appears from the data obtained from the higher density objects that the effect of WUP is noticeable but the effect of CP is more significant (Tables IV and VI). Consequently, both cold and warm detectors are useful but only with appropriate calibration. From this we may conclude that in the standardization of CBCT instruments which are using the same or a similar type of FPD, both WUP and CP factors are important. However, the CP is considerably more important than the WUP for the FPD in preparing comparable image quality with a fixed radiation dosage; therefore, it should be performed even in exceptional cases when the FPD hasn't had enough time to reach the steady-state temperature [72].

\subsubsection{The calibration of the ideal concentration of the contrast material solution by mapping-up the angiosome of the human face}

This anatomical study [82-84] was to define the intraosseous vascular territory (angiosomes [85]) of the facial artery. The clinical issue is whether ipsilateral facial artery anastomosis will guarantee blood supply to the ipsi- and contralateral mandibular symphyses and maxillae in allotransplantation. Each ipsilateral maxilla and mandibular bone segment showed contrast medium in the intraosseous vessels. In about half of cases, this also happened in the contralateral side of the maxilla and anterior mandible $[82,84]$.

An angiosome is a composite block of tissue that is supplied by source of vessels that span between the skin and bone [85]. The detailed three-dimensional mapping of the angiosomes of the mid-face and the neck are very important because of the rapid increase of requirements in reconstructive surgery and in facial transplantation. Usually for mapping of the angiosomes either blue ink injection in the blood vessels was used or angiography [89]. The question was whether it is possible, considering all the benefits, to use the so-called dental CBCT scan for the examination of this vascular system [82-84]. 
The aim of the study $[83,84]$ was to find a protocol and contrast material concentration for dental CBCT to make a setup for 3D mapping of the angiosomes of the face. It was important to find the contrast material concentration range to differentiate the compact surface of the bone from the entering vessels through the nutritive foramina, but reduce the artefacts. In this examination, a cadaver head or a block of the cadaver head was used (Figure 33 A). However, before the real anatomical examination, it was necessary to determine the optimal applied contrast material and the ideal range of the contrast material concentration. The arrows in Figure 33 B showed the location of the contrast material filled plastic tube in the phantom. For this preliminary study, different phantoms were used to model the cadaver heads and blocks (Figure $33 \mathbf{C}$ and D) during the dental CBCT acquisition. The advantage of using these phantoms was the ability to easily make many series with different concentrations of different types of contrast materials. These dental CBCT-examinations were reproducible with these phantoms [83].

However, this phantom technique does have many limitations because visualization of these artefacts needs bone and soft tissues around the contrast material filled vessels. Consequently, the dry mandible is not suitable for this use. Around the dry mandible, dental impression material was used with parallel small channels for the contrast material filled plastic tube (Figure 33 B, C and D) in order to mimic the soft tissue [83].
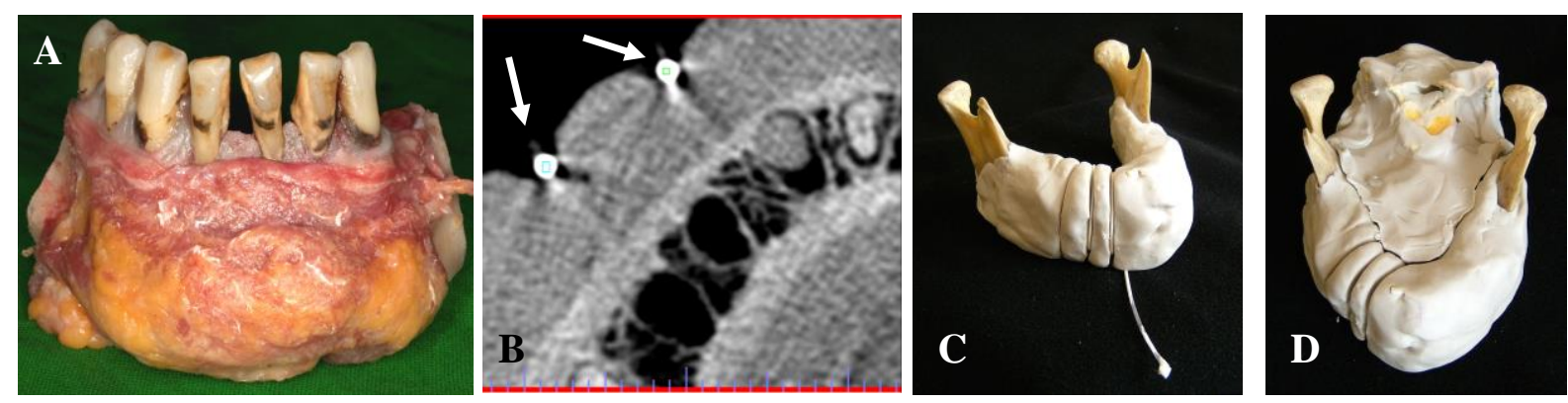

Figure 33 A: Photographs of a block. B: The image of different artefacts around the contrast material filled plastic tube in dental impression material of the phantom (preliminary study). C: The contrast material filled tube in the small channels of the dental impression material around the dry mandible (the phantom of the block: 'mandible'). D: The image of the phantom of the cadaver head (the phantom of the block supplemented with extra mass of cervical vertebras and impression material: 'mandible with spine') [83].

The image shown in Figure 33 B should be interpreted by comparing Figure 34, where the artefacts are seen as was discussed in Section 2.4.3. 

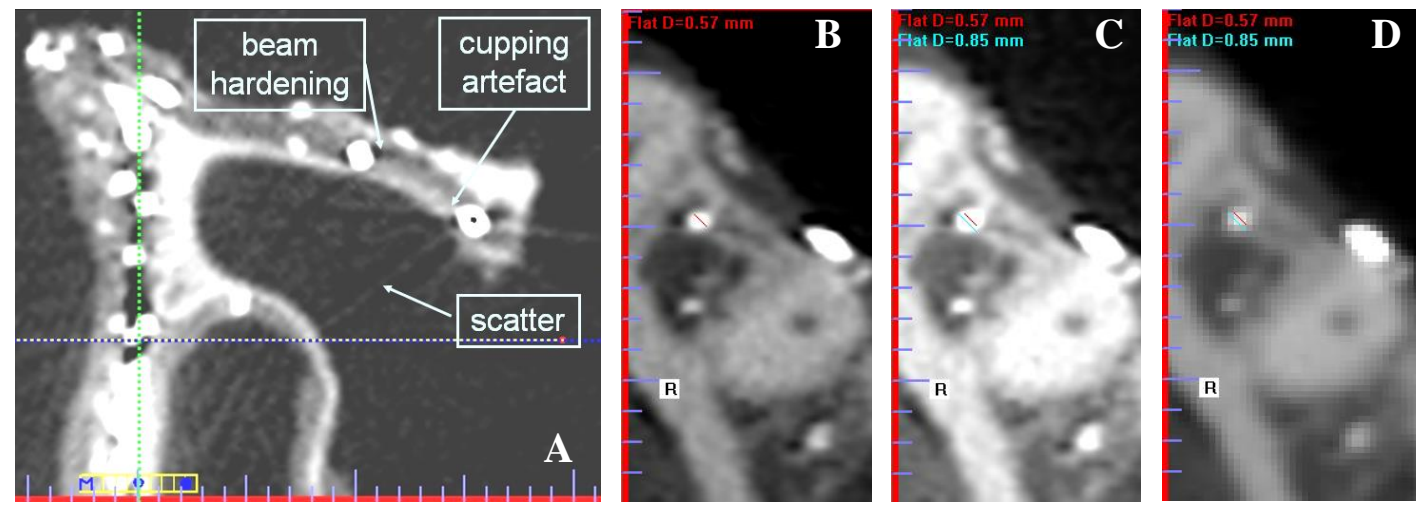

Figure 34 The presence of different artefacts in this examination. A: cupping artefact, scatter and beam hardening [16,17]. This image shows the enlarged part of a block and the presence of these artefacts are visible around the vessels, which were filled with a very high density contrast material solution. B, $\mathbf{C}$ and $\mathbf{D}$ images show the second problematic feature of the scan; for instance the diameter of a very high density structure depends on the brightness and contrast adjustment using CBCT-technique (Figure $34 \mathbf{B}$ and $\mathbf{C}$ ). On the other hand, if we see on the screen the structure of the chancellous bone, there is not the real data of the reconstructed image. This picture shows only the interpolation of the digital image pixels structure (Figure 34 D) [83].

Concentrating on the preliminary study, the next problem was the so called 'exomass effect' $[29,30,66]$. If a dental CBCT scan was taken of a patient, the nape was outside of the FOV. It has attenuated the X-ray beam but this mass is outside the field of reconstruction. This mass has caused a change in the grey values in the HU measurement $[37,39,47,66,75,76]$. Therefore, this artefact did affect the value of the ideal concentration of the applied contrast material solution as well. A removable inner part at this phantom was used, which compounds two cervical vertebras [39,66,83] within dental impression material (Figure 33 D). This phantom has modelled the human head (mandible with spine) and without the spine was only like a block (Figure 33 C). For this reason, the same contrast material was used by the phantom for two acquisitions, one with the two cervical vertebras and one without. The mean values of the grey scale measurements in HU of the different concentrations of Gastografin with and without the vertebras are visible in Figure 35. This figure shows a dilution test with Gastografin in the case of block (only mandible) and cadaver head (mandible with spine). The extra mass in the axial slice, the vertebra with impression material, causes the change in the measured grey values $[37,39,47,66,76,83]$. Two different grey values in HU can be measured, by block or cadaver head, using the same concentration of the Gastografin solution [83]. 


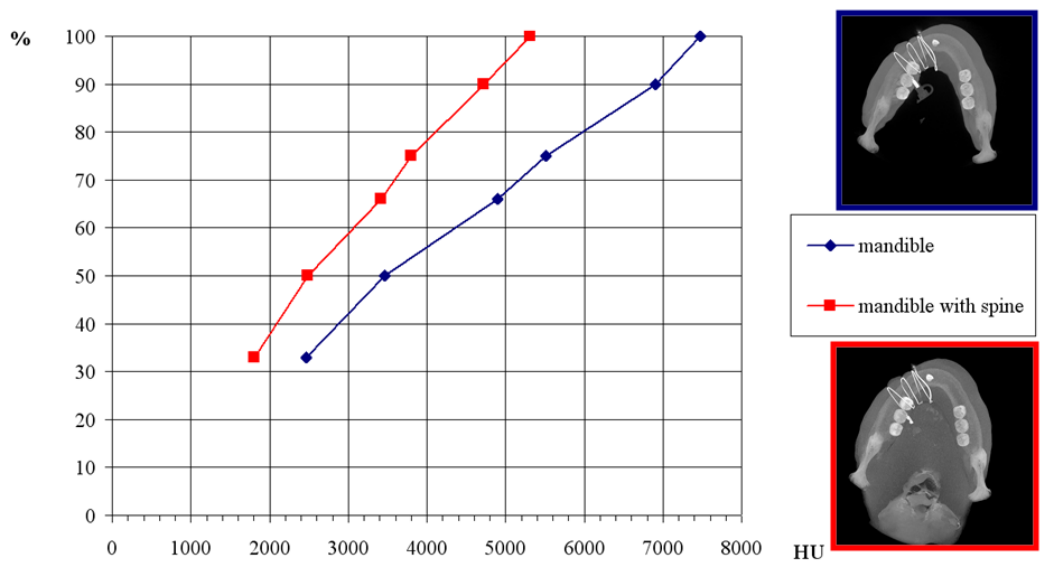

Figure 35 The functional dependence of the Gastografin contrast material concentration on the measured grey values in HU. In this research RD600 02 acquisition mode was used by iCAT Classic equipment [82-84].

As the result of this experiment, Figure 35 clearly indicates that, for example, a 3500 HU grey values $50 \%$ concentration is needed for a block (mandible-blue line) and about $66 \%$ concentration is needed for the cadaver head (mandible with spine-red line). Thus, we are able to show the contrast material filled vessels in the bone [83].

Furthermore, Figure 36 shows a series of dilution tests using different contrast materials. The optimal contrast solution turned out to be in the ranges of 3500-4000 HU. It was possible to differentiate the compact surface of the bone from the entering vessels through the nutritive foramina in 3DVR and MPR view (Figure 37) [83].

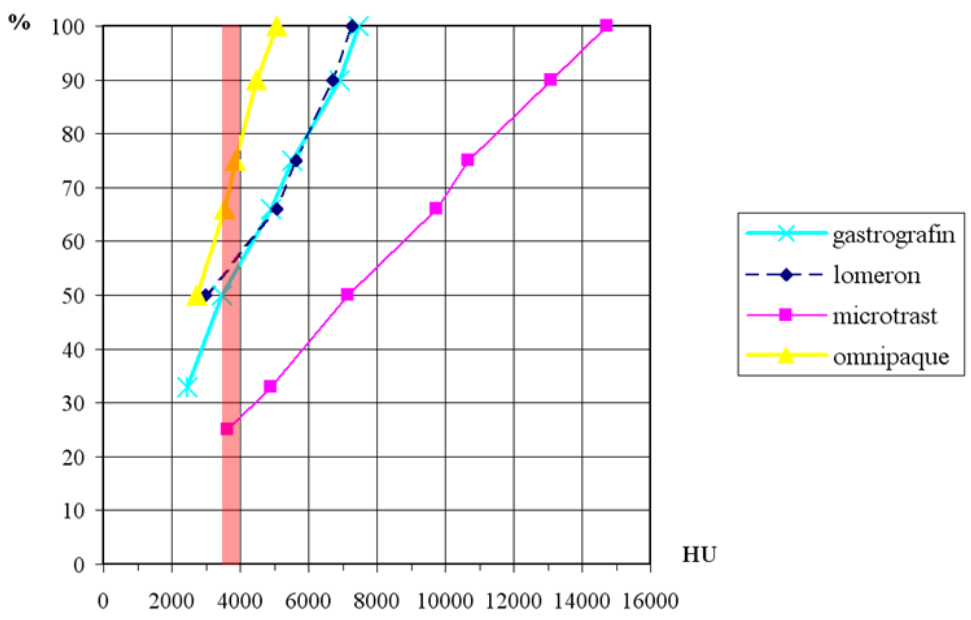

Figure 36 The series of dilution tests with different contrast materials using the mandible with spine phantom. This diagram shows the measured grey values of the different contrast materials in the function of the solutions concentrations. To differentiate the compact surface of the bone from the entering vessels through the nutritive foramina in iCAT Classic dental CBCT image was the optimal contrast solution between the ranges of 35004000 HU. In this research RD600 02 acquisition mode was used [82-84]. 

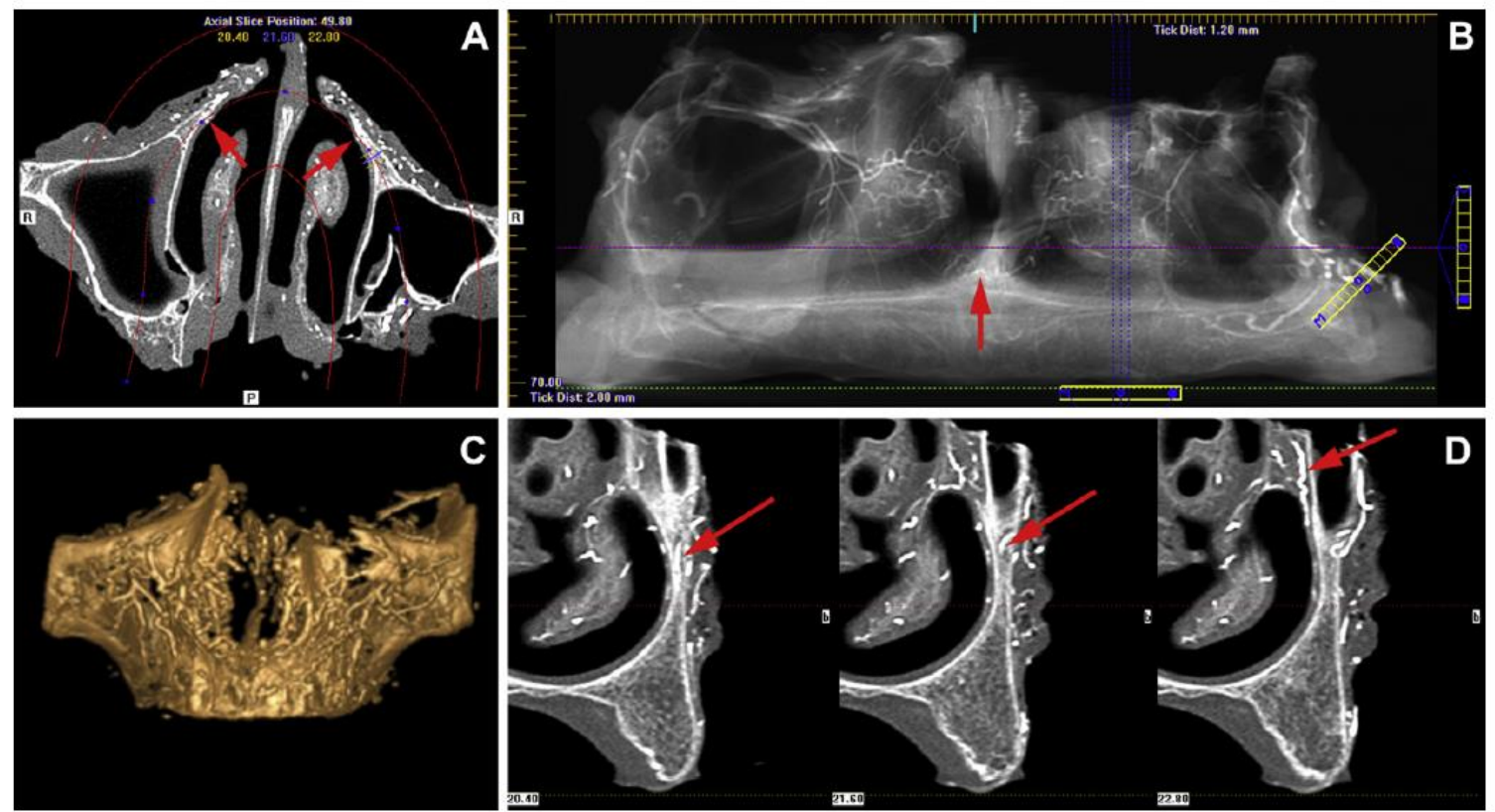

Figure 37 Dental CBCT images of contrast material filled block as published previously [82] A. Axial slice of the maxillae at the level of a Le Fort I osteotomy. Note the retrograde filling of the posterior alveolar arteries (arrows) on both sides. B: Reconstructed orthopantomogram image, depicting deep midline crossing arteries (arrow). C: Three-dimensional reconstruction. D: Sagittal slices of the ipsilateral maxilla. The contrast agent is visible within the bone (arrows) [82]. In this research RD600 02 acquisition mode was used by iCAT Classic equipment [82-84].

In summary, it may be said that using this predetermined concentration of the Microtrast contrast material solution (Microtrast, Guerbet GmbH, Sulzbach, Germany) it was possible to decrease the presence of artefacts and detect anastomosis between the angiosomes of right and left facial artery. These results are very useful for preoperative imaging in reconstructive surgery [82-84].

\subsubsection{High-quality image acquisition in dental CBCT by using the concept of} sequential cone beam computed tomography (SCBCT). The data collection as the third basic problem

The concept of sequential cone beam computed tomography (SCBCT) $[13,14,53,60]$ is shown in Figure 38 [53]. The essential point is that instead of utilizing the double rotational radiation as shown in Figure 38 A. The overlapping area shown in the middle of Figure $38 \mathbf{B}$ is analysed in the form as it illustrated in Figure 38 C [53]. 


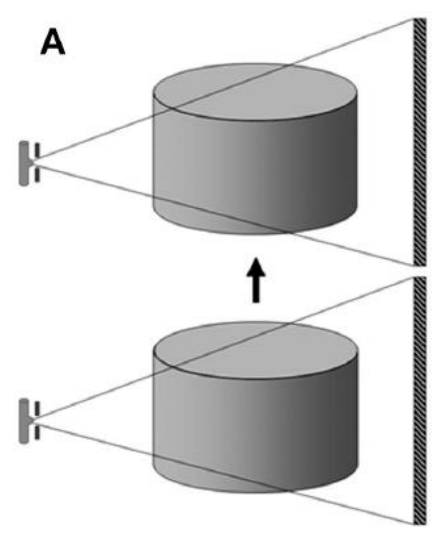

B

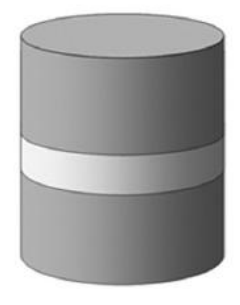

C

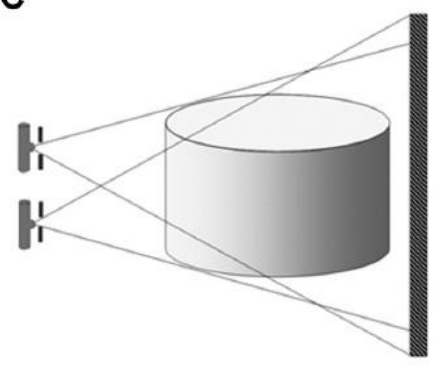

Figure 38 The schematic representation of basic acquisition procedures. A: iCAT Classic Extended Height acquisition $(20+20$-second exposition, 22-cm height optional extended field of view (EFOV)), which was reconstructed during fusion of 2 separate 300 projections. B: The overlapping 4-cm-high region (EFOV 04) of the 22-cm height extended height acquisition mode (white colour marked, 300 raw data (RD) + $300 \mathrm{RD}$ ) of the study configuration. The reconstruction of the EFOV 04 was made using both scans' RDs simultaneously. $\mathbf{C}$ : This method is proposed in the simplest way to achieve a double exposure overlapping cone beam computed tomography with 2 rotations using the same detector with a differently positioned and collimated $\mathrm{x}$-ray source within the top and bottom planes of the field of view. Using 2 x-ray sources simultaneously would increase the price of this new device [53].

Using the concept of sequential cone beam computed tomography (SCBCT) developed by Köhler, Proksa, and Grass in 2000 [60], which appears to be a generalization of the Tuy condition [31], we made a practical application for our CBCT scans. In this process, we used two circular orbits at different heights with reduced basic projection numbers within the same field of view (FOV). As a result of this, apparent density (i.e. grey value) fidelity (in HU) could be increased according to a single-cycle higher number basic projection acquisition. The clinical relevance is that the radiation dosage that the patient is exposed to during an examination is a definite point in question, which is discussed by previous authors [51]. The double exposure does not mean double dosage. In the double exposure dental CBCT, instead of a 600 basic projection data set (600 RD), two 300 basic projection data sets are used, and therefore no extra exposure occurs, as illustrated by Table II [53].

To satisfy the SCBCT requirements, the CBCT acquisition procedure consisted of two single-cycle, low-number, basic projection scans (300 RD + $300 \mathrm{RD})$ with parallel, central beams at two different fixed heights along the vertical dimension within the same FOV (Figure 38). The iCAT Classic (Imaging Sciences International, Hatfield, PA, USA) equipment was used for $20+20$-second duration exposure (300 RD + 300 RD), with 22-cm 
height optional expanded FOV and 0.4-mm thick slice scan with a 4-cm overlap. The reconstruction of this 4-cm height overlap region of the FOV (EFOV 04) does not stitch the reconstructed axial slice data of the two FOVs; the 2D projection RD acquisitions are used simultaneously [53].

The measurement made on water phantom (Figure 39), in the four cases illustrated in Table VIII, shows that the measurement at EFOV 04 (Figure 39 A) is the closest to the gold standard $0 \mathrm{HU}$ value and also has minimal amount of noise [53].

Table VIII. Measured density values (i.e. grey value) for the water phantom. AD: Mean apparent density in HU. SD: Standard deviation values of five acquisition methods using the water phantom [53].

\begin{tabular}{|l|c|c|c|c|c|c|c|c|c|c|}
\hline \multirow{2}{*}{$\begin{array}{l}\text { Distance from the } \\
\text { center }(\mathbf{m m})\end{array}$} & \multicolumn{2}{|c|}{ RD300 04 } & \multicolumn{2}{c|}{ RD600 04 } & \multicolumn{2}{c|}{ RD600 02 } & \multicolumn{2}{c|}{ EFOV 04 } & \multicolumn{2}{c|}{ MDCT } \\
\cline { 2 - 11 } & AD & SD & AD & SD & AD & SD & AD & SD & AD & SD \\
\hline 0.00 & -292.14 & 65.95 & -281.86 & 48.29 & -249.50 & 153.84 & -65.14 & 41.91 & -2.45 & 38.24 \\
\hline 16.00 & -298.97 & 64.09 & -290.12 & 46.67 & -258.69 & 141.73 & -57.90 & 43.45 & 2.77 & 39.10 \\
\hline 32.00 & -317.84 & 64.56 & -317.83 & 49.71 & -295.77 & 142.53 & -55.97 & 43.93 & 0.79 & 31.20 \\
\hline 48.00 & -364.69 & 66.64 & -375.89 & 50.39 & -365.51 & 146.69 & -65.15 & 41.07 & 2.62 & 23.39 \\
\hline 64.00 & -456.02 & 66.12 & -504.09 & 67.41 & -489.82 & 147.84 & -75.57 & 42.95 & 3.10 & 21.79 \\
\hline
\end{tabular}

Similar measurements were made on all four inserts of the ISI quality assurance phantom (air, acryl, low-density polyethylene (LDPE) and Teflon). The pattern they have shown is given in Figure $\mathbf{4 0}$ and the parameters of least square fit are given in Table IX [53].

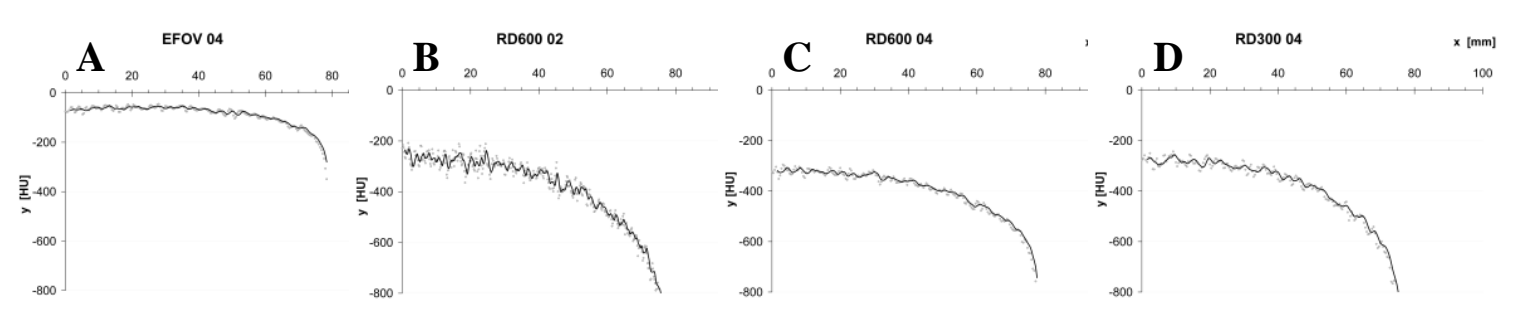

Figure 39 Water phantom apparent density (i.e. grey value) in the axial plane within the height of the central beam from the centre to the periphery. All diagrams were generated with ImageJ, version 1.42q (Wayne Rasband, National Institutes of Health, Bethesda, MD, USA). The horizontal axis is the distance from the isocenter toward the periphery. Note that the centre of the water phantom is at zero. A: EFOV 04. B: RD600 02. C: RD600 04. D: RD300 04. Properties for system and their acquisition protocols chosen for this study are in Table II [53].

(MDCT, multidetector computed tomography; EFOV, extended field of view; HU, Hounsfield units.) 
Table IX. Measured grey values for quality assurance phantom. AD: Mean apparent density in HU. SD: Standard deviation values of five acquisition methods using the standard Imaging Sciences International quality assurance phantom [53].

\begin{tabular}{|l|c|c|c|c|c|c|c|c|c|c|}
\hline & \multicolumn{2}{|c|}{ RD300 04 } & \multicolumn{2}{c|}{ RD600 04 } & \multicolumn{2}{c|}{ RD600 02 } & \multicolumn{2}{c|}{ EFOV 04 } & \multicolumn{2}{c|}{ MDCT } \\
\hline & AD & SD & AD & SD & AD & SD & AD & SD & AD & SD \\
\hline Teflon & 789.68 & 39.09 & 866.00 & 39.99 & 867.95 & 103.25 & 1009.02 & 36.73 & 965.94 & 17.72 \\
\hline LDPE & -378.51 & 49.36 & -372.44 & 45.24 & -334.10 & 99.54 & -119.32 & 28.80 & -104.10 & 18.01 \\
\hline Acryl & -119.68 & 38.80 & -127.34 & 35.22 & -79.81 & 93.42 & 135.94 & 26.73 & 115.16 & 16.61 \\
\hline Air & -997.25 & 7.29 & -1001.66 & 8.92 & -1000.00 & $0.00^{*}$ & -998.94 & 9.13 & -999.24 & 14.56 \\
\hline
\end{tabular}

*SD values cannot be determined due to saturation.

ISI phantom

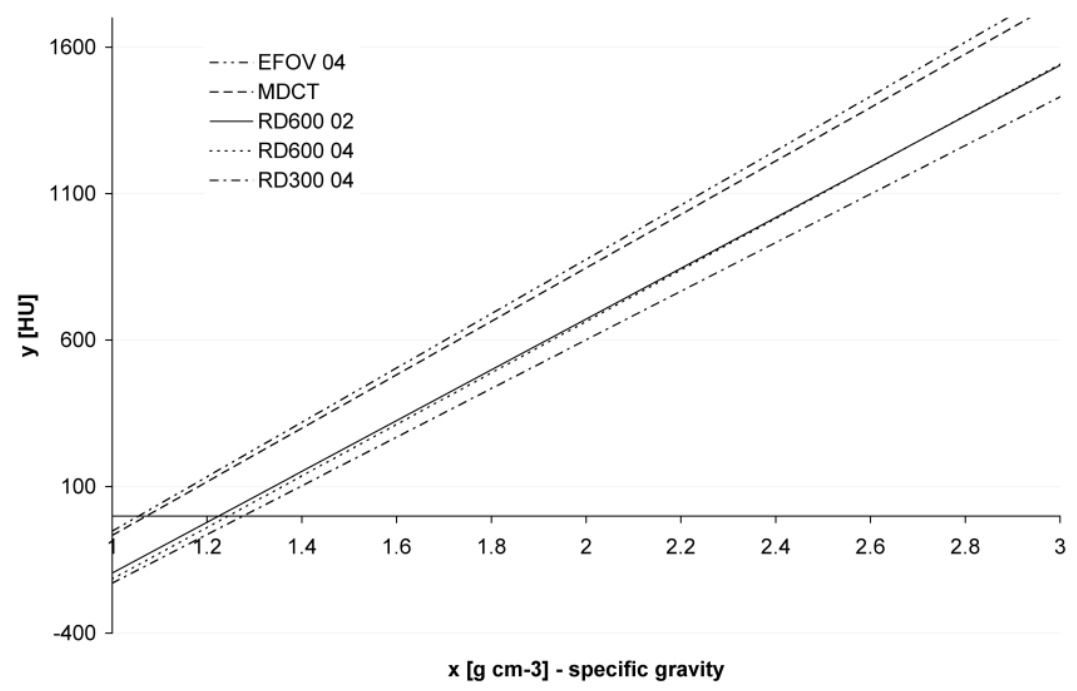

Figure 40 The graphical results of the linear regression analyses for different scans using the same Imaging Sciences International Inc (ISI) quality-assurance cone beam computed tomography phantom. X-axis: volumetric mass density, specific gravity $\left(\mathrm{g} / \mathrm{cm}^{3}\right)$. Y-axis: apparent density (HU) [53].

(MDCT, multidetector computed tomography; EFOV, extended field of view; HU, Hounsfield units.)

Table X. The calibration (equation) coefficients (A and B) and the significance ( $\mathrm{R}^{2}$ and SIG) of the correlation [53].

\begin{tabular}{|l|c|c|c|c|}
\hline & A & B & $\mathbf{R}^{\mathbf{2}}$ & SIG \\
\hline MDCT & 0,001094494 & 1,07327639 & 0,998 & 0,001 \\
\hline EFOV 04 & 0,001076877 & 1,057004494 & 1,000 & 0,000 \\
\hline RD600 02 & 0,001153867 & 1,224908296 & 0,992 & 0,004 \\
\hline RD600 04 & 0.001136747 & 1.245583669 & 0.986 & 0.007 \\
\hline RD300 04 & 0,001203064 & 1,277268949 & 0,991 & 0,005 \\
\hline
\end{tabular}

Linear regression was used to provide the relationship between the volumetric mass density (specific gravity, $\rho$ ) and apparent density (HU) within the 0.0 and $2.16 \mathrm{~g} / \mathrm{cm}^{3}$ range. $\rho=\mathrm{A} * \mathrm{HU}+\mathrm{B}$. 
With the reconstruction of two separate $300 \mathrm{RD}$ basic projection scans, satisfying the SCBCT requirements, achieved better AD fidelity (i.e. grey value) and lower image noise than other dental CBCT scan modes using the same iCAT Classic equipment. Moreover, in measurements using water and ISI quality-assurance phantom support in this reconstruction configuration (EFOV 04), we were able to obtain better grey values of water or hard tissues such as compact bone (corresponding to Teflon), and of dense regions of trabecular bone (corresponding to acryl) and soft tissues such as fat (corresponding to LDPE) [53].

\section{Conclusions}

The purpose of this dissertation was motivated by the as-low-as-reasonablyachievable (ALARA) principle which demands that the radiation dose for patients should be optimized to achieve the lowest practical level to address a specific clinical situation [72,77]. For this reason, it is of considerable importance that we obtain the best necessary image quality at a certain radiation level [72]. Thus, the purpose of this dissertation was the examination of grey values accuracy and improvement of image quality in dental Cone Beam Computed Tomography (CBCT) at given radiation level [53,63,72,82].

Thesis Points 1: It has been proven that in the case of a single tooth, it was possible to investigate the presence of dry soft tissue in a single tooth pulp chamber in the root canal. This was possible because there was no head around the investigated single tooth, consequently, the mass, and therefore the magnitude of X-ray scattering, in the FOV, was substantially reduced. This result is a clinical proof of previously published in vitro studies proving that the magnitude of noise in the reconstructed image depends on the mass and size of the material in the FOV [63].

Thesis Points 2: It was concluded that pre-processing methods are of significant importance. These include the warming-up period as well as the calibration process to reduce the noise in the reconstructed CBCT image to about a third of the full value [72].

Thesis Points 3: The noise can be minimized to about a third or a fourth of the total value by using the more accurate reconstruction algorithm (SCBCT), involving two separate rotations, with parallel central beams at 2 different fixed heights, during the image acquisition. Of course, the double exposure does not mean double dosage. For example, in the 
double exposure dental CBCT, instead of a 600 basic projection data set (600 RD), two 300 basic projection data sets are used, and therefore no extra exposure occurs [53].

Thesis Points 4: It was concluded that pre-processing methods are of significant importance. These include the warming-up period as well as the calibration process to optimise the function of the applied iCAT Classic flat panel detector and in order to reduce the presence of artifacts. Of the two processes the calibration process was more effective to achieve the aim of the thesis point then the warming-up period [72].

Thesis Points 5: It has been concluded that in the case of mapping of the angiosomes the calibration of contrast material concentration, is a highly effective method to reduce the presence of artefacts [82].

Thesis Points 6: It has been proven that in the case of a single tooth, it was possible to investigate the presence of dry soft tissue in a single tooth pulp chamber in the root canal. This was possible because there was no head around the investigated single tooth, consequently, the mass, and therefore the magnitude of X-ray scattering, in the FOV, was substantially reduced. The reduction of X-ray scattering eventually reduced the noise in the reconstructed image, as it has been concluded in Thesis Point 1. These changes also increased the contrast resolution and therefore yielded a better density response of the dental CBCT instrument [63].

Thesis Points 7: It was concluded, that the pre-processing methods, such as warmingup period and the calibration process, are of significant importance in improving the accuracy of grey values in the reconstructed dental CBCT image. The warming-up period is less important because it leads to only a $7.4 \%$ improvement, while the calibration process results in $13 \%$ accuracy increase. In contrast to these, both methods together yield only $15.7 \%$ improvement [72].

Thesis Points 8: It was concluded, that the application of a more accurate scanning and reconstruction algorithm, namely the double exposure overlap acquisition procedure involving sequential cone beam computed tomography (SCBCT), is of appreciable 
importance in improving the accuracy of grey values (i.e. apparent density) in the reconstructed dental $\mathrm{CBCT}$ image. The numerical improvements are the following:

- Teflon $27.8 \%$

- LDPE $68.7 \%$

- Water $82.0 \%$

- Acryl $214.3 \%$

It should be emphasized, that using iCAT Classic dental CBCT equipment, only the SCBCT algorithm gives positive grey values in the case of acryl. The $214.3 \%$ increase is due to the change from negative to positive of the grey value. This improvement has been achieved by using SCBCT instead of applying the Feldkamp algorithm or its modifications [53].

The various investigated methods aimed to improve image quality at a given level of radiation. The most dramatic improvement in image quality, i.e. in grey value accuracy and lower level of noise, was obtained by satisfying the sequential cone beam computed tomography (SCBCT) requirements. In future development a potentially promising step would be to program this method into new CBCT equipment and work together with software developers to fully achieve this potential as concluded in Paper 4 [53]. This paper was recently cited in the literature [90].

\section{$7 \quad$ Acknowledgments}

The author is acknowledging the scientific leadership and support of Professor Katalin Nagy, dean of the Faculty of Dentistry at the University of Szeged.

The author is grateful to VIP Dental Oral Radiology and Cone Beam CT Imaging Centres Ltd. for providing access to sophisticated X-ray imaging instruments. 


\section{$8 \quad$ References}

[1.] Brain P. Galen on bloodletting: a study of the origins, development, and validity of his opinions, with a translation of the three works. Cambridge, Cambridge University Press. 1986. p. 1.

[2.] Aufderheide AC. The Scientific Study of Mummies. Cambridge, Cambridge University Press. 2003. p. 5

[3.] Brock AJ (translator), Introduction. Galen. On the Natural Faculties. Edinburgh, W. Heinemann. 1916.

[4.] Claudii Galeni Pergameni. translated by Charles Joseph Singer, ed. Galen on anatomical procedures: De anatomicis administrationibus. London: Geoffrey Cumberlege, Oxford University Press. 1956. pp. 195-207.

[5.] Claudii Galeni Pergameni. "Galen on Anatomical Procedures". Proceedings of the Royal Society of Medicine. 1956. 49(10):833. PMC 1889206.

[6.] Claudii Galeni Pergameni (1528). "De usu partium corporis humani, libri VII, cap. IV". In Nicolao Regio Calabro (Nicolaus Rheginus). De usu partium corporis humani, libri VII (in Latin). Paris: ex officina Simonis Colinaei. p. 339.

[7.] Kusukawa, Sachiko. "De humani corporis fabrica. Epitome". Cambridge Digital Library. Retrieved 3 July 2014

[8.] Grosvenor ES, Wesson M. Alexander Graham Bell: The Life and Times of the Man Who Invented the Telephone. New York, Harry N. Abrahms Inc., 1997. p. 107.

[9.] Ferenczy K, Martonffy K. Fogászati radiológia. Semmelweis Kiadó, Budapest, 1992. pp. 11-14.

[10.] Fuhrmann A. Zahnärztliche Radiologie. Thieme, Stuttgart. 2003. pp. 12-15.

[11.] Düker J. Praxisleifaden Zahnärztliche Radiologie. Urban \& Fischer, Elsevier, München. 2006.

[12.] Zöller UG. Digitale Volumentomografie in der Zahn-, Mund- und

Kieferheilkunde. Berlin, Quintessenz Verlags GmbH. 2007.

[13.] Kalender WA. Computertomographie. $2^{\text {nd }}$ ed. Erlangen, Publicis Corporate Publishing. 2006.

[14.] Kalender WA. Computed Tomography. $3^{\text {rd }}$ ed. Erlangen, Publicis Corporate Publishing. 2011. 
[15.] Whaites E. Essentials of Dental Radiography and Radiology. $4^{\text {th }}$ ed. London, Elsevier. 2007.

[16.] Scarfe WC, Farman AG. Cone-Beam Computed Tomography. In Stuart CW, Michael JP, eds. Oral Radiology. Principles and Interpretation. St. Louis, Mosby. 2009. pp. 225-237.

[17.] Scarfe WC, Farman AG. Cone-beam computed tomography: Volume Acquisition. In Stuart CW and Michael JP, eds. Oral Radiology: Principles and Interpretation. St Louis, Mosby. 2014. pp. 185-198.

[18.] Hasse A, Landwehr G,Umbach E. Röntgen Centennial: X-rays in Natural and Life Sciences. Singapore, World Scientific Publishing Co. 1997. pp. 7-8.

[19.] Karjodkar FR. Textbook of Dental and Maxillofacial Radiology. New Delhi, Jaypee Brothers Medical Publishers Ltd. 2006. pp. 1-10.

[20.] Salamon H. A Magyar stomatológia (fogászat) története. Budapest, Magyar Stomatológiai Történeti Hivatal. 1942.

[21.] Seynaeve PC, Bross JI. The history of tomography. J Belge Radiol. 1995;78(5):284-288.

[22.] Webb S. From the Watching of the Shadows. The Origins of Radiological Tomography. Bristol, IOP Publishing Ltd. 1990.

[23.] Nagy F, ed. Magyar tudóslexikon A-tól Zs-ig. Budapest, MTESZ; OMIKK. 1997. p. 346.

[24.] United State Patent Office. A. F. ZULAUF. PANORAMIC X-RAY APPARATUS 1,408,559. Mar. 07, 1922.

[25.] Radon JH. Über die Bestimmung von Funktionen durch ihre Integralwerte längs gewisser Mannigfaltigkeiten. Ber. vor Sächs. Akad. Wiss. 1917;69:267-277.

[26.] Cormack AM: Representation of a function by its line integrals, with some radiological applications. J. Appl. Physics 1963;34:2722-2727.

[27.] Hounsfield GN: Computerized transverse axial scanning (tomography). Part I. Description of a system. Br. J. Radiol. 1973;46:1016.

[28.] Bates S, Beckmann L, Thomas A, Waltham R. Godfrey Hounsfield: Intuitive Genius of CT. London, The British Institute of Radiology. 2012.

[29.] Schulze R, Heil U, Groß D, Bruellmann DD, Dranischnikow E, Schwanecke U, et al. Artefacts in CBCT: a review. Dentomaxillofac Radiol. 2011;40:265-273. 
[30.] Molteni R. Prospects and challenges of rendering tissue density in Hounsfield units for cone beam computed tomography. Oral Surg Oral Med Oral Pathol Oral Radiol. 2013;116: 105-119.

[31.] Tuy HK. An inversion formula for cone-beam reconstruction. SIAM J Appl Math. 1983;43:546-552.

[32.] Plachtovics M. Digital Volume Tomography: Cone beam CT imaging in dentistry, oral and maxillofacial surgery (original article in Hungarian: A Digitális Volumentomográfia: Cone Beam CT-k a fogászatban, az arc-, állcsont- és szájsebészetben.) MRadiol 2009;83:254-262.

[33.] Haßfeld S, Rother U. Röntgendiagnostik in der Mund-, Kieferund Gesichtshirurgie. Der MKG-Chirurg. 2008;2:137-145.

[34.] Swennen GRJ, Schutyser F, Hausamen J-E. Three dimensional cephalometry. Berlin, Springer. 2005. p. 5.

[35.] Plachtovics M. Practical advice on the application of cone beam CT imaging in implantology I. (original article in Hungarian: Gyakorlati tanácsok a digitális volumentomográfia implantológiai alkalmazásához I.) Implantológia 2011;8:22-27.

[36.] Mozzo P, Procacci C, Tacconi A, Martini PT, Andreis IA. A new volumetric CT machine for dental imaging based on the conebeam technique: preliminary results. Eur Radiol. 1998;8:1558-1564.

[37.] Pauwels R, Stamatakis H, Manousaridis G. et al. Development and applicability of a quality-control phantom for dental cone-beam CT. J Appl Clin Med Phys 2011;12:245-260.

[38.] 3D Accuitomo FDP - XYZ Slice View Tomograph. J Morita MFG Corp., 2007.

[39.] Katsumata A, Hirukawa A, Okumura S, Naitoh M, Fujishita M, Ariji E, et al. Effects of image artifacts on gray-value density in limited-volume cone-beam computerized tomography. Oral Surg Oral Med Oral Pathol Oral Radiol Endod. 2007;104:829-836.

[40.] Dale AM. Color Atlas of Cone Beam Volumetric Imaging for Dental Applications. Chicago, Quintessence. 2008.

[41.] Nemtoi A, Czink C, Haba D, Gahleitner A. Cone beam CT: a current overview of devices. Dentomaxillofac Radiol 2013;42:20120443. 
[42.] Tyndall DA, Price JB, Tetradis S, Ganz SD, Hildebolt C, Scarfe WC. Position statement of the American Academy of Oral and Maxillofacial Radiology on selection criteria for the use of radiology in dental implantology with emphasis on cone beam computed tomography. Oral Surg Oral Med Oral Pathol Oral Radiol 2012;113:817826.

[43.] Jackowsky J, Peters H, Hölzle F. Praxisleifaden Zahnärztliche Chirurgie. München, Urban \& Fischer, Elsevier. 2007.

[44.] Lagravére MO, Carey J, Ben-Zvi M, Packota GV, Major PW. Effect of object location on the density measurement and Hounsfield conversion in a NewTom 3G cone beam computed tomography unit. Dentomaxillofac Radiol. 2008;37:305-308.

[45.] González-García R, Monje F. The reliability of cone-beam computed tomography to assess bone density at dental implant recipient sites: a histomorphometric analysis by micro-CT. Clin Oral Implants Res. 2012;23:1-9.

[46.] Mah P, Reeves TE, McDavid WD. Deriving Hounsfield units using grey levels in cone beam computed tomography. Dentomaxillofac Radiol. 2010;39:323-335.

[47.] Oliveira ML, Tosoni GM, Lindsey DH, Mendoza K, Tetradis S, Mallya SM. Influence of anatomical location on CT numbers in cone beam computed tomography. Oral Surg Oral Med Oral Pathol Oral Radiol. 2013;115:558-564.

[48.] Silva IM, Freitas DQ, Ambrosano GM, Bóscolo FN, Almeida SM. Bone Density: comparative evaluation of Hounsfield units in multislice and cone-beam computed tomography. Braz Oral Res. 2012;26:550-556.

[49.] Azeredo F, de Menezes LM, Enciso R, Weissheimer A, de Oliveira RB. Computed gray levels in multislice and cone-beam computed tomography. Am $J$ Orthod Dentofacial Orthop. 2013;144:147-155.

[50.] Reeves TE, Mah P, McDavid WD. Deriving Hounsfield units using grey levels in cone beam CT: a clinical application. Dentomaxillofac Radiol. 2012;41:500-508.

[51.] Horner K, Islam M, Flygare L, Tsiklakis K, and Whaites E. Basic principles for use of dental cone beam computed tomography: consensus guidelines of the European Academy of Dental and Maxillofacial Radiology. Dentomaxillofac Radiol. 2009;38:187-195.

[52.] iCAT Classic Operator's Manual (2010), Imaging Sciences International, Hatfield, PA, USA 
[53.] Plachtovics M, Bujtar P, Nagy K, Mommaerts MY. High-quality image acquisition by double exposure overlap in cone beam computed tomography. Oral Surg Oral Med Oral Pathol Oral Radiol. 2014;117:760-767. doi: 10.1016/j.oooo.2014.02.024. Epub 2014 Mar 13.

[54.] eXam Vision Operator's Manual (2008), Imaging Sciences International, Hatfield, PA, USA

[55.] Gendex CB-500 Operator's Manual (2009), Imaging Sciences International, Hatfield, PA, USA

[56.] Veraviewepocs 3D. F40 and R100 with innovative 3D Reuleaux FOV. J Morita MFG Corp., 2011.

[57.] 3D Accuitomo 80. J Morita MFG Corp., 2008.

[58.] Lagravére MO, Fang Y, Carey J, Toogood RW, Packota GV, Major PW.

Density conversion factor determined using a cone-beam computed tomography unit NewTom QR-DVT 9000. Dentomaxillofac Radiol. 2006;35:407-409.

[59.] Divinyi T: Orális Implantológia. Budapest, Semmelweis Kiadó, 2007.

[60.] Köhler TH, Proksa R, Grass M. A fast and efficient method for sequential cone-beam tomography. Med Phys. 2001;28:2318-2327.

[61.] Fleiner J, Weyer N, Stricker A. Cone-Beam Computed Tomography. CBCT Diagnostics. $2^{\text {nd }}$ ed. Freiburg, 2einhalb GmbH. 2013.

[62.] Plachtovics M. Practical advice on the application of cone beam CT imaging in implantology II. (original article in Hungarian: Gyakorlati tanácsok a digitális volumentomográfia implantológiai alkalmazásához II.)

Implantológia 2012;9:30-38.

[63.] Plachtovics M, Patonay L, Kerenyi T: What Pal Szechenyi's tooth tells us:

Modern investigation of a tooth with digital volume tomography. In Lilla Alida Kristof and Vilmos Toth (ed.): In honour of Archbishop Pal Szechenyi. Contribution for the path of life and the results of the study of the mummy of Nagycenk. (Original chapter and book in Hungarian: Amiről Széchényi Pál foga mesél. Korszerü fogvizsgálat DVT-vel. In: Széchényi Pál érsek emlékezete. Adalékok az életúthoz és a nagycenki múmia vizsgálatának eredményei.) Universitas-Győr Nonprofit Kft., 2012. Győr, Hungary. ISBN 978-963-9819-95-5. pp. 136-141. 
[64.] Draenert FG, Coppenrath E, Herzog P, Müller S, Mueler-Lisse UG. Beam hardering artefacts occur in dental implant scans with the NewTom ${ }^{\circledR}$ cone beam CT but not with the dental 4-row multidetector CT. Dentomaxillofac Radiol 2007;36:198203.

[65.] Schulze D, Blessmann M, Pohlenz P, Wagner KW, Heiland M. Diagnostic criteria for the detection of mandibular osteomyelitis using cone-beam computed tomography. Dentomaxillofac Radiol. 2006;35:232-235.

[66.] Katsumata A, Akiko H, Shinji O, Munetaka N, Masami F, Eiichiro A, et al. Relationship between density variability and imaging volume size in cone-beam computerized topographic scanning of the maxillofacial region: an in vitro study. Oral Surg Oral Med Oral Pathol Oral Radiol Endod. 2009;107:420-425.

[67.] Yamashina A, Tanimoto K, Sutthiprapaporn P, Hayakawa Y. The reliability of computed tomography (CT) values and dimensional measurements of the oropharyngeal region using cone beam CT: comparison with multidetector CT. Dentomaxillofac Radiol. 2008;37:245-251.

[68.] Physics. In Stuart CW and Michael JP eds. Oral Radiology: Principles and Interpretation. St Louis, Mosby. 2014. pp. 1-15.

[69.] Miracle AC, Mukherji SK. Conebeam CT of the Head and Neck, Part 1: Physical Principles. Am J Neuroradiol. 2009;30:1088-1095.

[70.] Nackaerts O, Maes F, Yan H, Couto Souza P, Pauwels R, Jacobs R. Analysis of intensity variability in multislice and cone beam computed tomography. Clin Oral Implants Res. 2011;22:873-879.

[71.] Araki K, Maki K, Seki K, Sakamaki K, Harata Y, Sakaino R, et al. Characteristics of a newly developed dentomaxillofacial X-ray cone beam CT scanner (CB MercuRayTM): system configuration and physical properties. Dentomaxillofac Radiol. 2004;33:51-59.

[72.] Plachtovics M, Goczán J, Nagy K. The effect of calibration and detector temperature on the reconstructed Cone Beam CT image quality. A study for the workflow of the iCAT Classic equipment. Oral Surg Oral Med Oral Pathol Oral Radiol. 2015;119:473-480. doi: 10.1016/j.oooo.2014.12.009. Epub 2014 Dec 31.

[73.] The SEDENTEXCT Project Radiation protection: cone beam CT for dental and maxillofacial radiology. Evidence based guidelines. Geneva, Switzerland: European Commission; 2011. Available from: http://wwwsedentexcteu/guidelines 
[74.] Swennen GR, Schutyser F. Three dimensional cephalometry: spiral multislice vs cone-beam computed tomography. Am J Orthod Dentofacial Orthop. 2006;130:410-416.

[75.] Pauwels R, Nackaerts O, Bellaiche N, Stamatakis H, Tsiklakis K, Walker A, Bosmans H, Bogaerts R, Jacobs R, Horner K. SEDENTEXCT Project Consortium. Variability of dental cone beam CT grey values for density estimations. Br J Radiol. 2013;86:20120135.

[76.] Bryant JA, Drage NA, Richmond S. Study of the scan uniformity from an iCAT cone beam computed tomography dental imaging system. Dentomaxillofac Radiol. 2008; 37:365-374.

[77.] The American Dental Association Council on Scientific Affairs. The use of cone-beam computed tomography in dentistry. An advisory statement from the American Dental Association Council on Scientific Affairs. JADA 2012;143:899-902.

[78.] Safety and Protection. In Stuart CW and Michael JP, eds. Oral Radiology: Principles and Interpretation. St Louis, Mosby. 2014. pp. 29-40.

[79.] Metzler P, Zemann W, Lübbers HT, Guggenberger R, Lüssi A, Obwegeser JA, et al. Bone mineral density measurements performed by cone-beam computed tomography in the bisphosphonate-related osteonecrosis-affected jaw. Oral Radiol. 2012;28:101-108.

[80.] i Dixel One Volume Viewer Operation Instructions (Ver. 2.0.0). J Morita MFG Corp., 2010.

[81.] Plachtovics M, Turak O, Osvay M: Examination of cone beam CT imaging by radiation dose measurements. Oral Presentation at the $17^{\text {th }}$ International Congress of DentoMaxilloFacial Radiology, 2009, Amsterdam, Netherland.

[82.] Molnar G, Plachtovics M, Baksa G, Patonay L, Mommaerts MY. Intraosseous territory of the facial artery in the maxilla and anterior mandible: Implications for allotransplantation. J Craniomaxillofac Surg. 2012;40:180-184. doi: 10.1016/j.jcms.2011.03.019. Epub 2011 Apr 1.

[83.] Plachtovics M, Molnar G, Baksa G, Mommaerts MY. The use of Digital Volume Tomography (Cone Beam CT) for mapping of the angiosome of the face. Oral Presentation at the Congress of the European Association for Cranio-MaxilloFacial Surgery, Brugge, Belgium, 2010. 
[84.] Molnar G, Baksa G, Plachtovics M, Patonay L, Mommaerts MY. Facial allotransplantation- Can the maxilla and mandibular symphysis survive on the facial artery? Oral Presentation at the Congress of the European Association for CranioMaxillo-Facial Surgery, 2010, Brugge, Belgium.

[85.] Houseman ND, Taylor GI, PanW-R: The angiosomes of the head and neck: anatomic study and clinical applications. Plast Reconstr Surg 2000;105:2287-2313.

[86.] Ranogajec-Komor M, Osvay M, Dosimetric Characteristics of Different TL Phosphors. Radiation Protection Dosimetry 1986;17:379-384.

[87.] Chotas HG, Dobbins JT, Ravin CE. Principles of Digital Radiography with Large-Area, Electronically Readable Detectors: A Review of the Basics. Radiology. 1999;210:595-599.

[88.] Kalender WA, Kyriakou Y. Flat-detector computed tomography (FD-CT). Eur Radiol. 2007;17:2767-2779.

[89.] Szabó Gy. Szájsebészet, maxillofacialis sebészet. $2^{\text {nd }}$ ed. Budapest, Semmelweis Kiadó; 1999.

[90.] Pauwels R, Jacobs R, Singer SR, Mupparapu M. CBCT-based bone quality assessment: are Hounsfield units applicable? Dentomaxillofac Radiol. 2015;44,20140238. DOI: 10.1259/dmfr.20140238. 


\section{Appendices}

\subsection{Mathematical Background of Computed Tomography}

"The respective formula and some simple cases are illustrated in" Figure A1 ". The simplest case is given by a measurement of a homogeneous object with monochromatic radiation (case 1); this case does not necessarily demand tomographic imaging, but it is familiar to us from many different measurement procedures. The intensity falls off exponentially with absorber thickness. Attenuation, defined as the natural logarithm of the ratio of primary intensity to attenuated intensity, is given in this case in a simple manner as the product of the linear attenuation coefficient $\mu$ and the absorber thickness $d$. If the absorber thickness is known $\mu$ can be determined directly. The distribution of $\mu$ along the ray path remains unknown, however.'[14]

"Case 2 in" Figure A2 "representing a simple inhomogeneous object, is of great interest. The contribution to total attenuation resulting from each ray path interval depends on the local value of the attenuation coefficient $\mu_{i}$. Summation over the path intervals, even for simply structured objects, has to be carried out in general with small increments di and therefore can be expressed as the integral over $\mu$ along the ray path. CT consist of measuring many such line integrals exactly. Radon showed in his early work [Radon, 1917] that the twodimensional distribution of an object characteristic can be determined exactly if an infinite number of line integrals is given. A finite number of measurements of the distribution of the attenuation coefficient $\mu_{(x, y)}$ is sufficient to compute an image to a good approximation. A single measurement only, as given in projection radiography, will not allow us to solve for $\mu_{i}$ in case 2 or for the distribution $\mu_{(x, y)}$ in general.

Before explaining how the measurement has to be carried out and how an image can be computed it must be said that the linear attenuation coefficient may depend strongly on energy. In measuring intensities - and this is done automatically in today's CT systems - we also integrate over all energy intervals as illustrated for case 3 of "Figure A1 ". The dependence on energy may yield problems, above all beam hardening effects. However, this can also be used to advantage in dual energy methods for material-selective measurements. If we also consider a potential dependence of attenuation coefficient is given as $\mu_{(x, y, E, t) .}$ A dependence of $\mu$ on time can be generated by the administration of contrast media or be given by physiology, for example in lung tissue as a function of inspiratory volume. In the following 
sections we will focus on the simple case of measuring and computing $\mu_{(x, y)}$ only for a given slice position z.'[14]
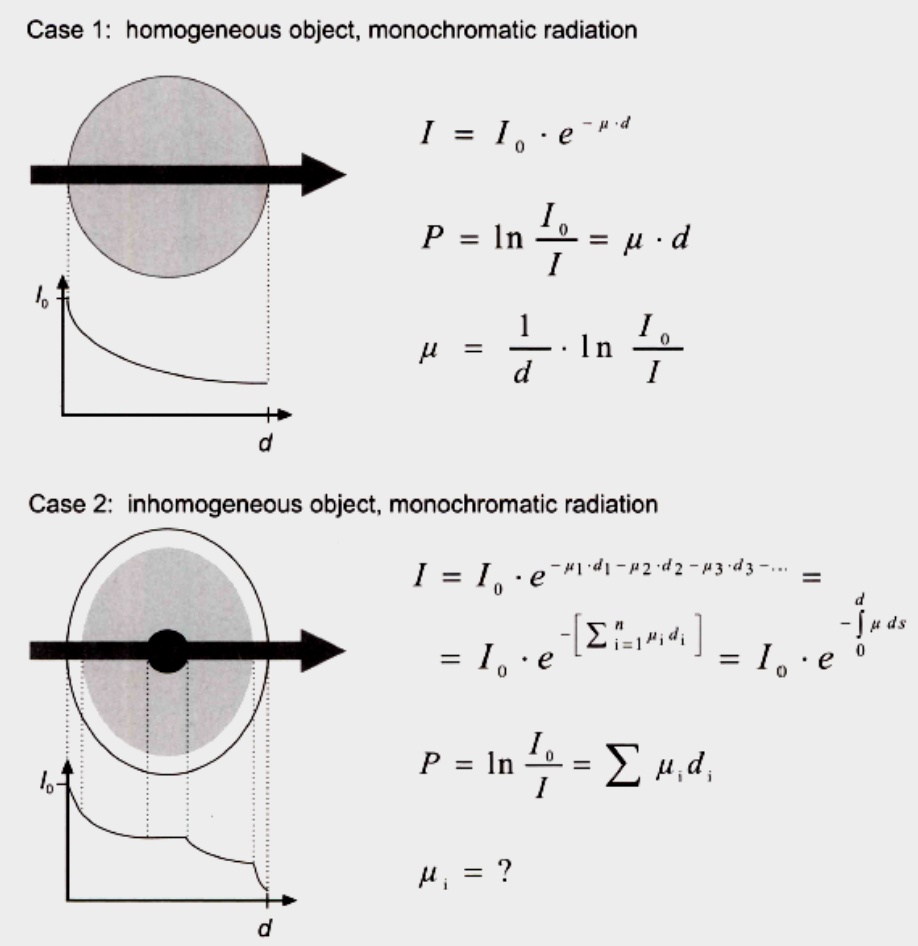

Case 3: inhomogeneous object, polychromatic radiation

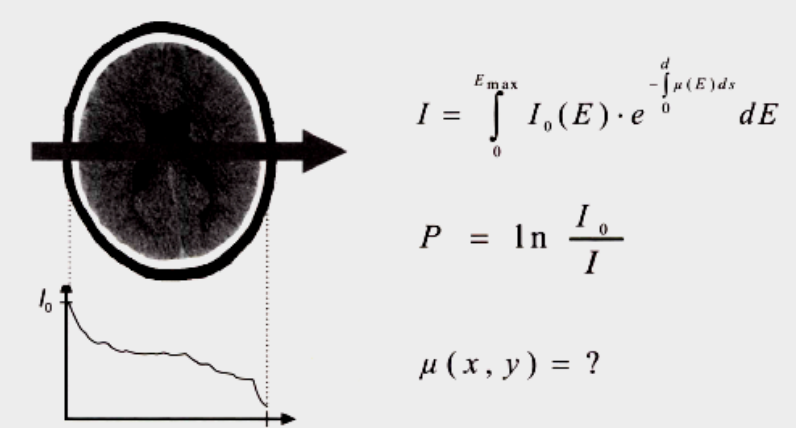

Figure A1 "What do we measure in CT? The intensity I of radiation. The attenuation value, i.e. the projection value $P$, results and thus, in the simplest case, the attenuation coefficient $\mu$ (case 1). For inhomogeneous objects tomographic imaging is necessary to determine the distribution $\mu_{(x, y)}$." Formulated by Kalender in chapter 1.4 of [14].

'In the simplest case of an image matrix with only four pixels $(2 x 2$ matrix) two measurements for two projections will yield a system of four equations and four unknowns which can be solved easily (Figure A2). The extension to a $3 \times 3$ matrix with nine unknowns can also be solved easily with twelve measured values given as assumed in this schematic representation. These so-called algebraic reconstruction techniques (ART) were actually used in the early days of CT. The image was computed in an iterative fashion, i.e. by repeating the 
calculation in an effort to improve accuracy with each step. For larger data volumes, finer image matrices and the higher demand on image quality ART approaches led to unacceptably high computation times.'[14]
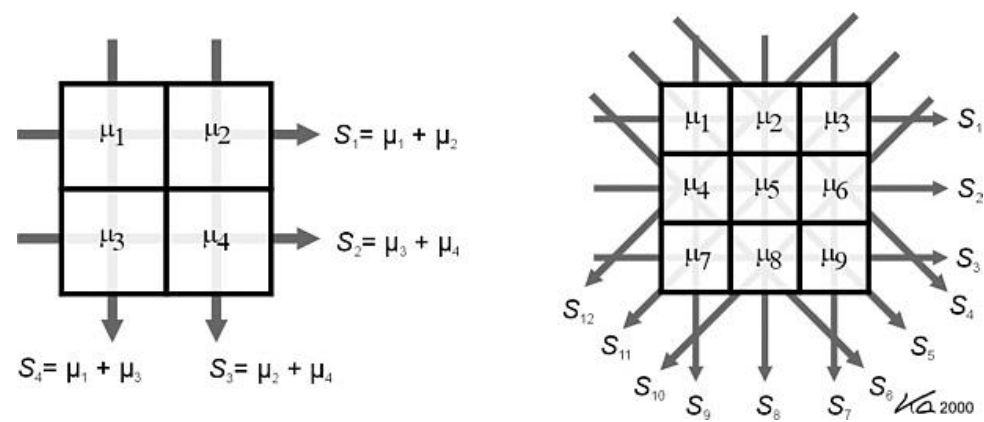

Figure A2 'How do we compute a CT images? Algebraic procedures are the most easily comprehensible approach to image reconstruction. The $N^{2}$ unknown values of an $N x N$ image matrix can be determined by solving a system of linear equations. For larger matrices this has to be done iteratively.' Formulated by Kalender in chapter 1.4 of [14].

\subsection{EU Guidelines: An Overview of Indications}

The first person who outlined the application and the main indications of dental CBCT technique for head and neck in his textbook was Eric Whaites. His book is entitled Essentials of Dental Radiography and Radiology (4 ${ }^{\text {th }}$ Edition, 2007). In his book [15] he summarised the main indications as follows.

'Cone beam CT has the potential to revolutionize imaging in all aspects of dental and maxillofacial radiology. It has already been shown to be particularly valuable in:

- Investigation of all conditions affecting the mandible or maxilla including cysts, tumours, giant cells lesions and osseous dysplasias

- Investigation of the maxillary antra

- Investigation of the TMJ

- Implant assessment

- Localization of unerupted teeth or odontomes

- Assessment of lower third molars and identification of the relationship with the mandibular canal

- Investigation of fractures of the mandible or middle third of the facial skeleton

- Multiplanar imaging of the teeth, peiapical and periodontal tissues with the high resolution scanner'[15] 
Another milestone appeared in 2011. A report prepared by the SEDENTEXCT project [73] provides an evidence based guidelines for radiation protection for cone beam CT for dental and maxillofacial radiology. The following quotation outlines the motivation of the comity prepared the report.

'SEDENTEXCT was a collaborative project that aimed to acquire key information necessary for sound and scientifically based clinical use of Cone Beam Computed Tomography (CBCT) in dental and maxillofacial imaging. In order that safety and efficacy are assured and enhanced in the "real world", a parallel aim was to use this information to develop evidencebased guidelines dealing with justification, optimisation and referral criteria for users of dental CBCT. The aim of this document is to provide such evidence-based guidelines to professional groups involved with CBCT in dental and maxillofacial imaging, including:

- Dental and Maxillofacial Radiologists

- Dentists working in primary care and their assistants

- Radiographers/Imaging technicians

- Medical Physicists

- Equipment manufacturers and suppliers

The core guidance in preparing the document has been from the two relevant Council Directives of the European Union:

Directive 96/29/Euratom, of 13 May 1996, laying down the basic safety standards for the protection of the health of workers and the general public against the dangers arising from ionising radiation (Basic Safety Standards Directive)

Directive 97/43/Euratom, of 3 June 1997, on health protection of individuals against the dangers of ionising radiation in relation to medical exposure (Medical Exposures Directive)

Beyond these sources, the detailed guidelines have been prepared by systematic review of the currently available literature. No exposure to X-rays can be regarded as completely free of risk, so the use of dental CBCT by practitioners implies a responsibility to ensure appropriate protection.

This document supersedes the Provisional Guideline document published in May 2009, incorporating new research, including work carried out within the SEDENTEXT project itself. 
Guidelines are not a rigid constraint on clinical practice. Local variations will be required according to national legislation, healthcare provision and practice and the unique clinical circumstances of patients.

I hope that the document will be of help to professional groups and contribute to optimizing the use of ionizing radiation in dental imaging. '[73] 
I 


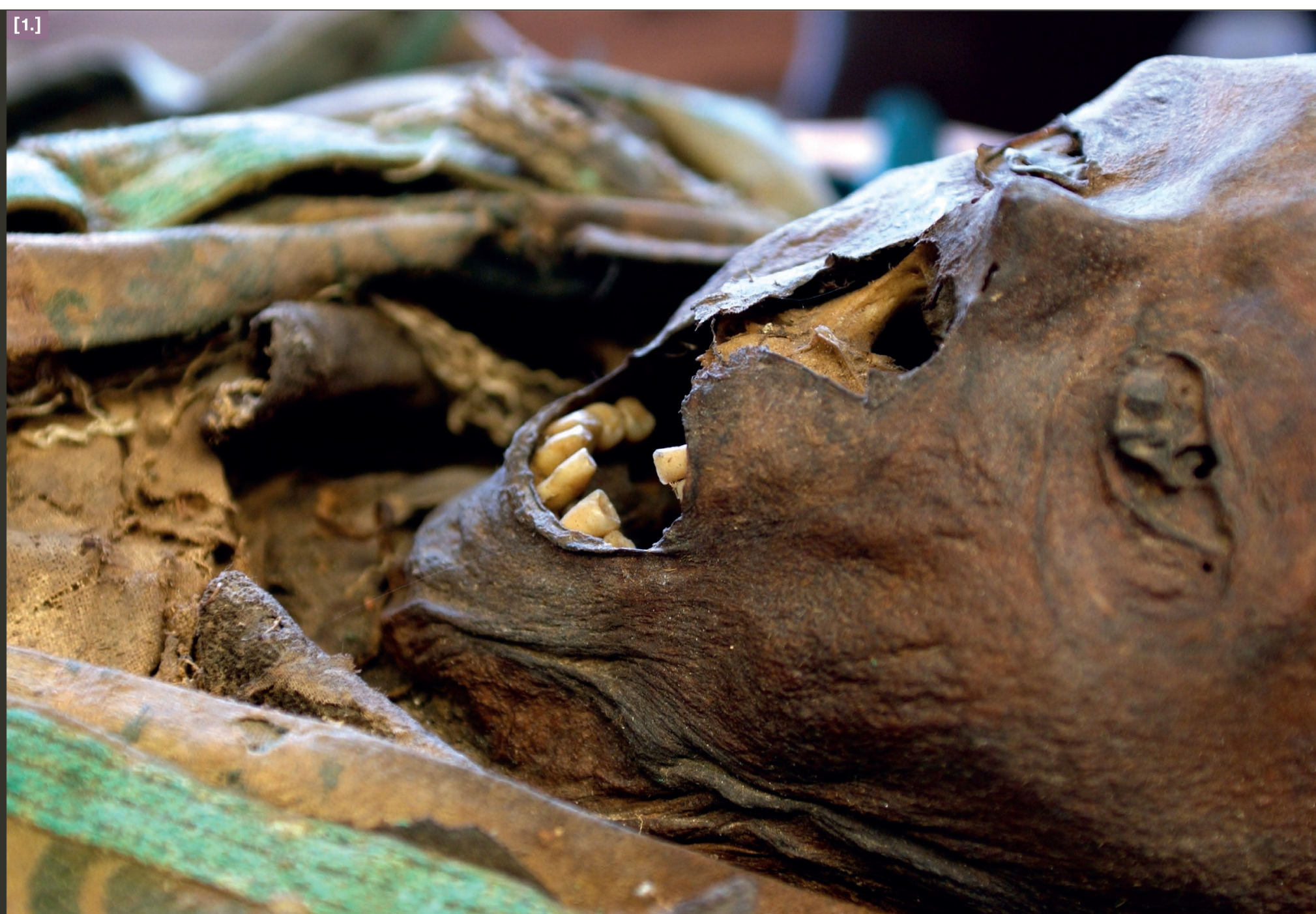

Plachtovics Márk

Patonay Lajos

Kerényi Tibor

\section{Amirôl Széchényi Pál foga mesél. Korszerú fogvizsgálat DVT-vel}

A kötet fejezeteit áttekintve látható, hogy a kutatók többsége Széchényi Pál múmiáját (1. és 6. kép) vizsgálhatta, vagy az ơ életútjához köthetô épületekről, történelmi összefüggésekról írhatott. Ezzel szemben nekünk csak egy felsó kisőrló fog jutott (2/a. kép), ami 2007-ben, a múmia endoszkópos vizsgálatakor lett eltávolítva a szájüregból. Az elvégzett vizsgálatoknak kettős célja volt: egyrészt a különálló kisőrlő fog fogászati és radiológiai kutatása, másrészt a Széchényi Pál állitólagos megmérgezéséról elterjedt legenda cáfo- lata vagy megerôsítése az eltávolított fog energiadiszperzív röntgenspektometriai vizsgálata segítségével.

Nemcsak fogorvosi és antropológiai, hanem röntgendiagnosztikai szempontból is érdekes ismeretekhez juttatott ennek az egyetlen fognak a digitális volumentomográfiai (DVT) vagy más néven fogászati Cone Beam CT- (СВCT) vizsgálata. Az eredmények ismertetése előtt azonban érdemes röviden áttekinteni a fogászati-szájsebészeti röntgendiagnosztika történetét és alapjait. ${ }^{1}$ 
1895. november 8-án fedezte fel Wilhelm Conrad Röntgen a róla elnevezett sugarat, majd 1896. január 12-én Otto Walkoff készítette az első fogászati röntgenfelvételt (úgynevezett „kisröntgen” felvételt). Ettől kezdve a fogak és a foggyökér körüli csontállomány megjelenítése árnyékképként vált lehetôvé, azaz a röntgensugár forrása és a film közötti képletek egymásra vetülve jelentek meg (3/a. kép). Ezzel a technológiával a térbeli rekonstrukció csak korlátozottan, azaz két, egymással szöget bezáró irányú röntgenfelvétel analizálásával volt elérhető a szakemberek számára. A felfedezést követő közel száz év viszont nem hozott olyan technikai újítást, mely lehetôvé tette volna például egy vizsgált fognak a részletes, roncsolás nélküli háromdimenziós leképezését.

1972-ben Godfrey Hounsfield megépítette az első „computertomograph” (CT) készüléket, majd 1989-ben megjelent az első spirál CT. Ezzel a digitális felvételi eljárással vált először lehetôvé az emberi test leképezése elmosódás- és elfedésmentes rétegek sorozatával, de még ez a technológia sem volt elég fejlett egyetlen fog kellően részletes megjelenítéséhez. A fejlesztőket több cél is vezérelte: a nagyobb felbontás, a jobb képminốség és a rövidebb felvételi idô elérése. A régebbi legyezőszerű sugárnyaláb (Fan Beam) helyett a piramis vagy kúp alakú sugárnyaláb alkalmazása (Cone Beam) két előnnyel is szolgált: nőtt a felvételkészítés sebessége és jobban kihasználhatóvá vált a röntgencső teljesítménye. Az egy-és négyszeletes CT-k még sugárkapuik révén legyezőszerú sugárnyalábot használtak, majd a következô generáció készülékei - a 16 szelet leképzésére képes CT-k - már kúp alakban széttérố röntgensugárforrást alkalmaztak. Az általános jellegű Cone Beam elnevezés tehát a sugárterjedés geometriai tulajdonságából eredt, és mára számtalan, különbözô célra gyártott CT-készülék gyűjtőneve lett: a 16 vagy több szeletes CT, a dual source CT, a PET-CT, a C-kar, az angiográfiában és a radioterápiában használt készülékek is ide tartoznak. A felbontás növelése révén a CT-készülékekre jellemző detektorsorok helyett egyes készülékekben megjelentek a korábban már máshol is használt képerôsítôs rendszerek, majd később a síkpaneldetektorok.

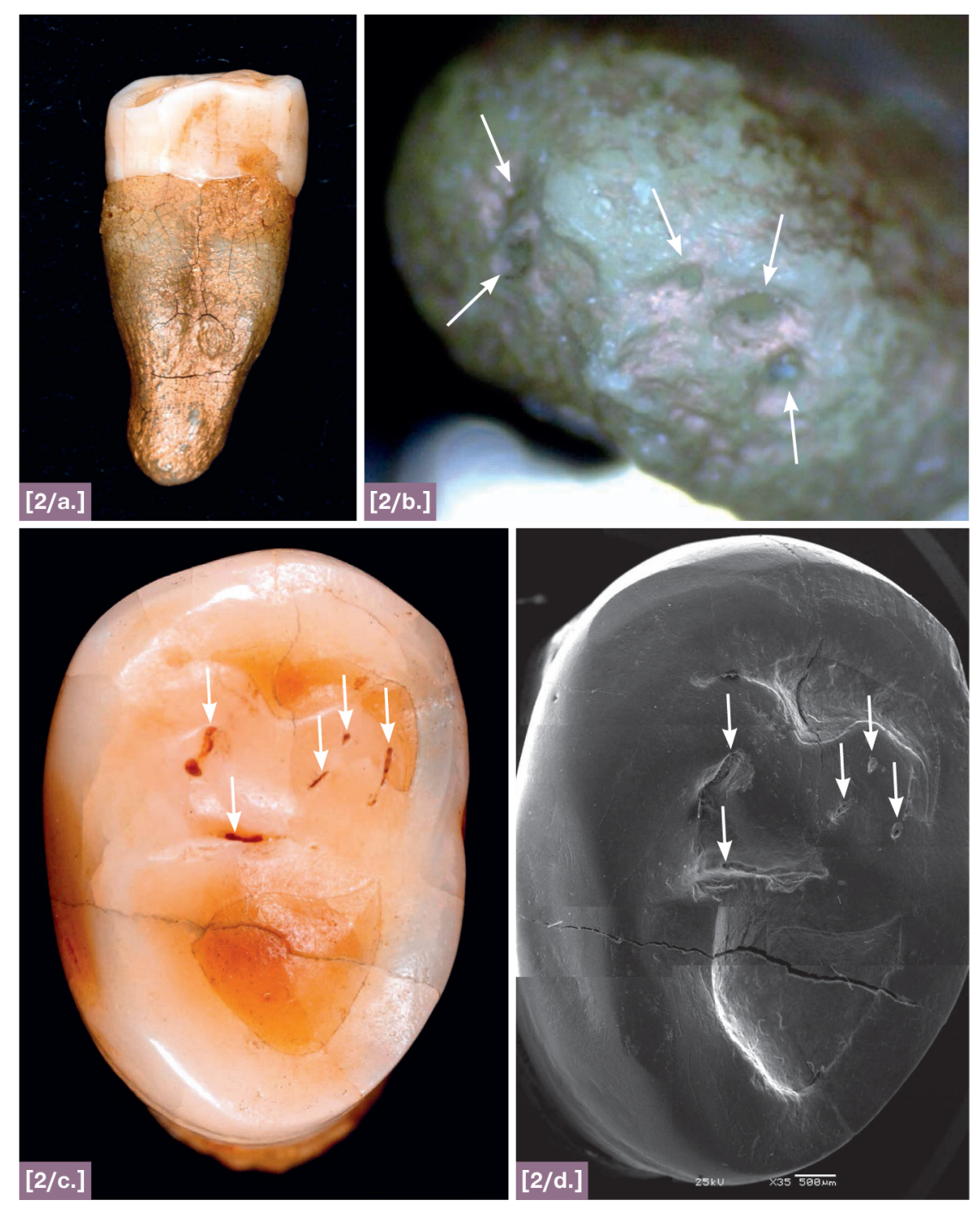

Végül a felbontás már nem szabott gátat a fogászati-szájsebészeti felhasználásnak, és 1997-ben el is készült az elsô ilyen célra gyártott Cone Beam CT-készülék, melynek detektora képerôsítővel kapcsolt CCD (image intensifier/charge coupled device combination) volt: a NewTom. Ez külsó megjelenésében és a beteg fektetett elhelyezése miatt még konvencionális CT-re hasonlított, de lágyszövet kvalitatív vizsgálatára nem volt alkalmas, csak keményszövet megjelenítésére. A DVT-felvétel felbontása nagyobb, a felvétellel járó sugárterhelés viszont már alacsonyabb volt, mint a hagyományos CT-felvételeknél: utóbbiak 1200-3300 $\mu$ Sv effektív sugárterhelésével szemben egy „átlagos”, 20 másodperces

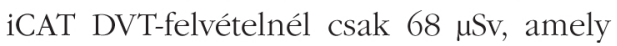

[1. kép] Széchényi Pál múmiája. Nagy Károly Zsolt felvétele, 2007. készített fényképfelvételek (2/a., 2/b. $2 / c$.$) , valamint a rágófelszín scanning$ elektromikroszkópos képe (2/d.).

Patonay Lajos (2/a., 2/c.) és Kerényi Tibor (2/b., 2/d.) felvételei, 2010.
[2. kép] A vizsgált alsó kisőrlő fogról

Az alábbiakhoz lásd elsősorban a következő szakirodalmat: Kalender W. A.: Computer-tomographie. Erlangen, 2006. White S. C. - Pharoah M. J.: Oral radiology: principles and interpretation. St. Louis, 2009. Plachtovics M.: A digitális volumentomográfia. Cone Beam CT-k a fogászatban, az arc-, állcsont- és szájsebészetben. Magyar Radiológia 83 (2009). 254-262. p. 

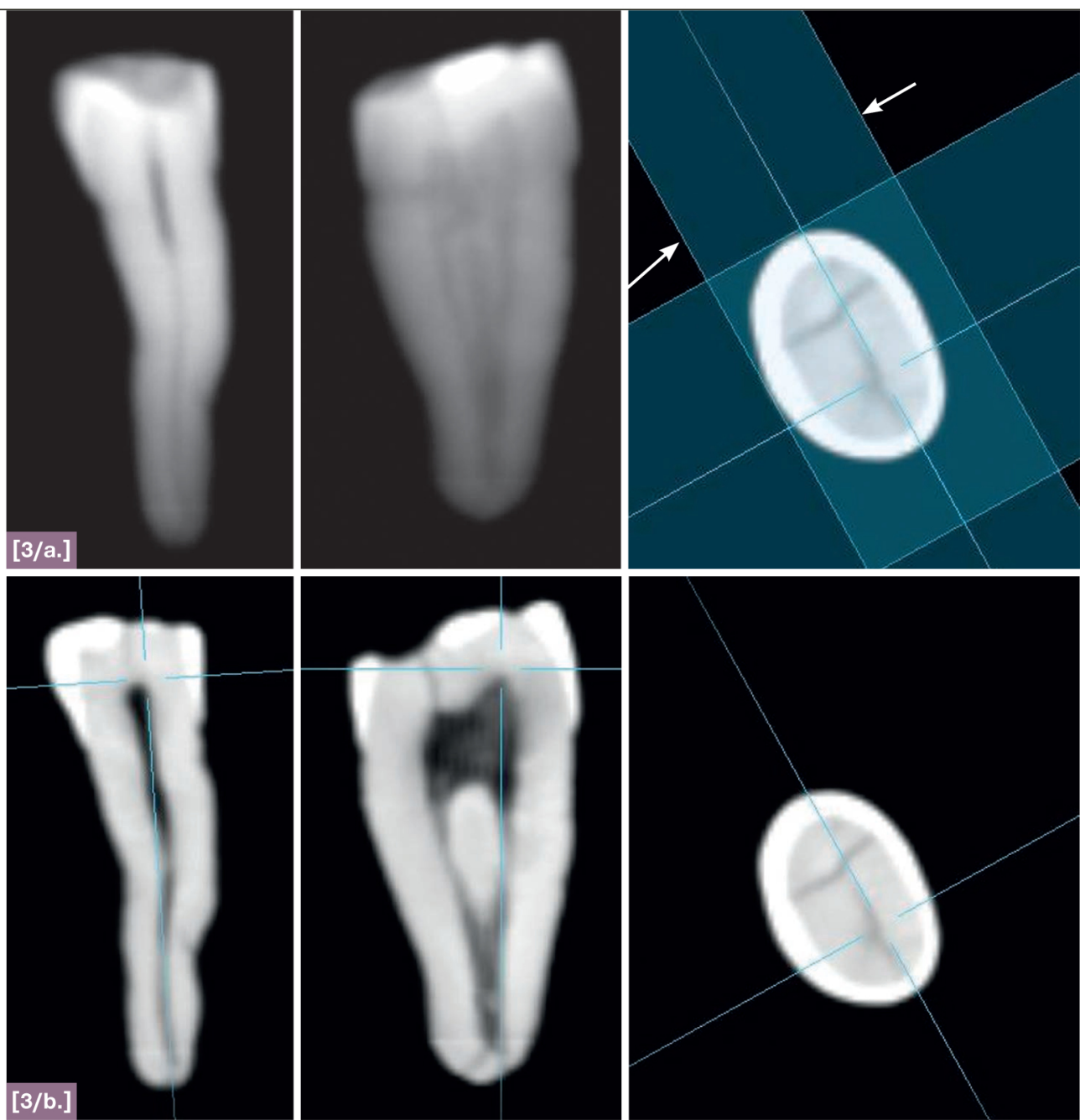

[3. kép] A vizsgált fog DVTfelvételének a teljes keresztmetszet egymásra vetítésével (3/a.), illetve a DVT-technológia biztosította $0,2 \mathrm{~mm}$-es rétegvastagsággal $(3 / \mathrm{b}$.) rekonstruált metszeti képei. Az előbbi a hagyományos kétdimenziós röntgenfelvételek képi megjelenítésének felel meg: itt együtt látható az összes réteg, a jobb felső képen lévő kék mezőknek megfelelő sávban. Plachtovics Márk felvételei, 2010 közelítőleg megegyezik egy BudapestNew York repülóút sugárterhelésével. A felvételben mérhető denzitásértékek viszont nem pontosak, továbbá homogén objektum vizsgálatakor - a hagyományos CT-vel összevetve - a leképezett térfogaton belül is jelentős eltéréseket mutatnak.

Ezekbốl három fontos tényezó következik: a DVT-készülékkel leképezett térfogatban a denzitásértékek mérése pontatlan; a DVT-felvétel a hagyományos CT-vel ellentétben utólag nem „ablakolható", azaz egyes denzitástartományok nem ábrázolhatóak részletgazdagabban; a DVT csak magas denzitású képletek, például csontszövet vizsgálatára alkalmas, de lágyrész, például idegszövet kvalitatív vizsgálatára nem. (Utóbbihoz fontos megjegyezni, hogy a fogbél üregében található összeszáradt pulpa maradványa is lágyszövetnek számít.)

Széchényi Pál felsô kisốrlô fogának scanning elektromikroszkópos vizsgálatát követően került sor a DVT-vizsgálatra, melyet Watech Picasso Pro típusú berendezéssel (E-WOO Technology Co.) végez- tünk. Az alkalmazott röntgenvizsgálat során a rekonstruált szeletvastagság mérete 0,2 mm volt. Ezt követôen fényképfelvételek készültek a fogról, majd a DVT-felvételnél is nagyobb felbontást eredményezó, hasonló elven múködő, kísérleti célokra kifejlesztett nano CT-készülékkel (MEDISO Kft.) készítettünk újabb felvételeket. A fog szerkezetének roncsolását, azaz a harántmetszeti csiszolatok készítését követốen újabb scanning elektromikroszkópos és energiadiszperzív röntgenspektometriai vizsgálatok következtek.

A scanning elektromikroszkópos vizsgálat során végzett kontrasztozás következtében a foggyökér cementállományát vékony aranyréteg fedte ( $2 / a$. kép). Lupe nagyítással jól megfigyelhető a gyökércsúcs több apró nyílása: a vizsgált fog gyökércsatornáiban futó olyan ér- és idegképletek nyomai, melyek a gyökércsúcson nem egy közös, hanem több kisebb csatornán érték el a környezó csontállományt (2/b. kép). A rágófelszín, melynek itt egymás mellett a fényképe ( $2 / c$. kép) és a scanning elektromikroszkópos felvétele látható ( $2 / d$. kép), 
szintén sok információval szolgált. Manapság már csak elvétve találkozunk idős embereknél ilyen erôsen kopott, mégis ilyen mértékben ép, szuvasodásmentes zománcú, tehát jó állapotú fogkoronafelszínnel. Ez több tényezóvel is magyarázható.

Az elsô a táplálkozási szokások, továbbá a táplálék összetételének megváltozása. Napjainkra a táplálék szénhidrát-, pontosabban fogalmazva cukortartalma a 17-18. századhoz képest jelentősen megnôtt, rosttartalma viszont lecsökkent. Így a rostok rágásának következtében kialakuló öntisztulás mértéke is lecsökkent, míg a fogak jobban ki vannak téve a szénhidrátok okozta szuvasodásnak.

A másik tényező, hogy a 19. század második felében megjelenô hengermalmok előtt még malomkővel végezték a gabona őrlését, melynek következtében jelentős mennyiségú abrazív anyag, azaz a malomkő apró, levált darabkái kerültek a táplálékba. Az intenzív rágás, továbbá ennek a tápláléknak a fogyasztása is hozzájárult a rágófelszín nagyfokú kopásához (attritio), ami jól megfigyelhetố a vizsgált fogon.

Bár a 17-18. században a maihoz hasonló szájápolás nem létezett, az előbb személynél a fogbél elhalásával és erôs fájdalommal jártak volna, de az itt láthatóak a halál beállta után alakultak ki a fog kiszáradásának következtében.

Az alkalmazott DVT-felvételi technika segítségével három előnyre tettünk szert. Az elsố, hogy a fogvizsgálathoz nem volt szükség hagyományos kétdimenziós röntgenfelvételek elkészítésére, mert ilyen megjelenítésủ képek a DVT-felvétel adatállományából bármikor tetszés szerinti rétegvastagsággal és elvetítési iránnyal rekonstruálhatók (3/a. kép). (A hagyományos CT-felvételek felbontásuk miatt erre a célra nem ideálisak.)

A fog vizsgálata során további előny volt, hogy a DVT-felvétellel tetszőleges irányú 0,2 mm-es rétegvastagságú keresztmetszeti kép megjelenítésére is lehetőség van (3/b. kép). Ezeknek a "szeleteknek” a mozgatása révén a vizsgált fogról, pontosabban annak keményszöveti állományáról részletgazdag ábrázolás és számos információ nyerhetô. A kisôrlő fog hossztengelyére merőlegesen mozgatott síkon is megfigyelhetôek a halál beállta után a keményszövetben kialakult repedések. A nagyfelbontású képszerkezet tetszés sze-

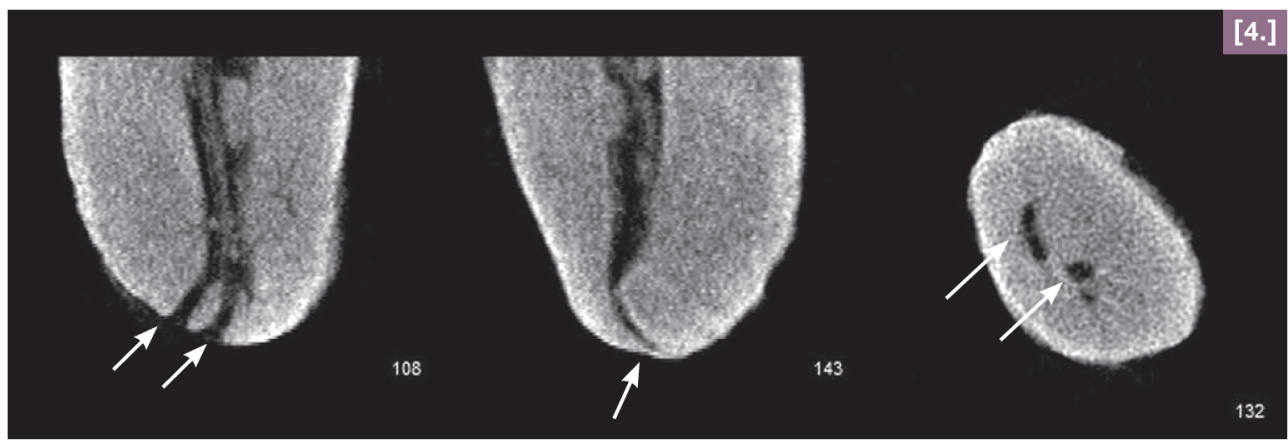

említett két tényező következményeként a táplálkozás során fokozott volt a rágófelszín öntisztulása. Ugyanakkor a vizsgált fognál az erôs kopás ellenére is láthatunk a fogzománc fejlôdése során kialakult keskeny, szuvasodásmentes barázdákat, melyek nemcsak hogy nem rendelkeznek az öntisztulás képességével, de még a mai módszerekkel sem lennének tisztán tarthatóak $(2 / c$. és $2 / d$. kép). Mindkét felvételen jól láthatóak ezek a természetes barázdák az erősen lekopott rágófelszínen (nyilakkal jelölve). A rágófelszín felén vagy teljes egészén futó repedések élô rinti lefutású, kiváló képminôséget biztosító síkok kijelölését teszi lehetôvé, de az eltávolított fogról készített ilyen képeken a lágyszövetnek, tehát a fogbélnek nyoma sincs. A felbontás további fokozásával (nano CT) a gyökércsúcs csatornaelágazódásának még részletesebb megjelenítése vált lehetôvé (4. kép).

A DVT-felvételi technika harmadik elónye esetünkben, hogy bár a fogbél lágyszövetének kvalitatív vizsgálatára nem volt lehetőség, de kvantitatív vizsgálatára igen. A DVT-felvételen a negatív kontrasztot biztosító levegố jelenlétében jól rekonst-
[4. kép] A vizsgált alsó kisőrlő fog gyökércsúcsa, ahol jól megfigyelhetőek az apró csatornácskák. A MEDISO Kft. nano CT-felvétele (az alkalmazott szeletvastagság 36 нm), 2010. 


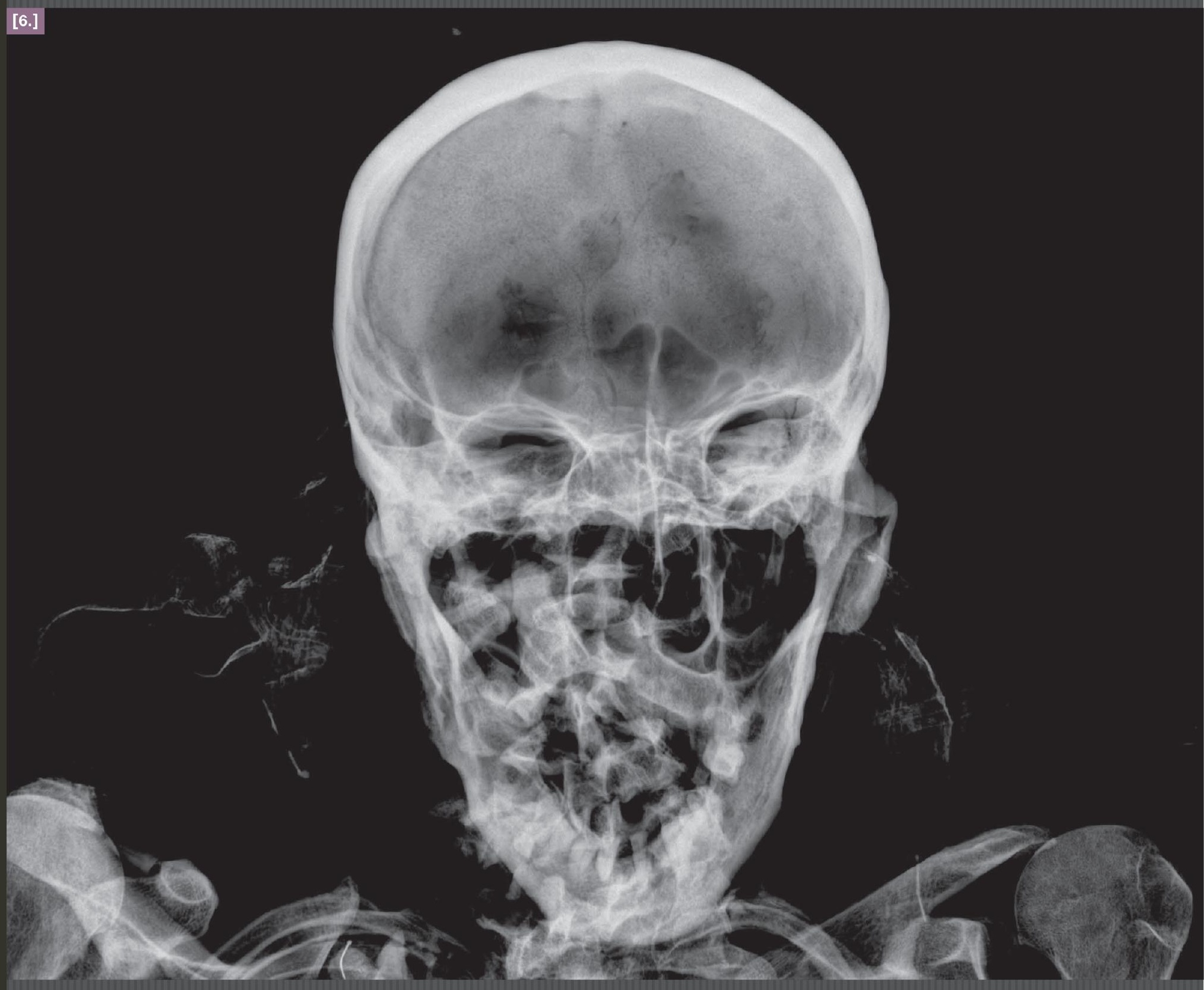



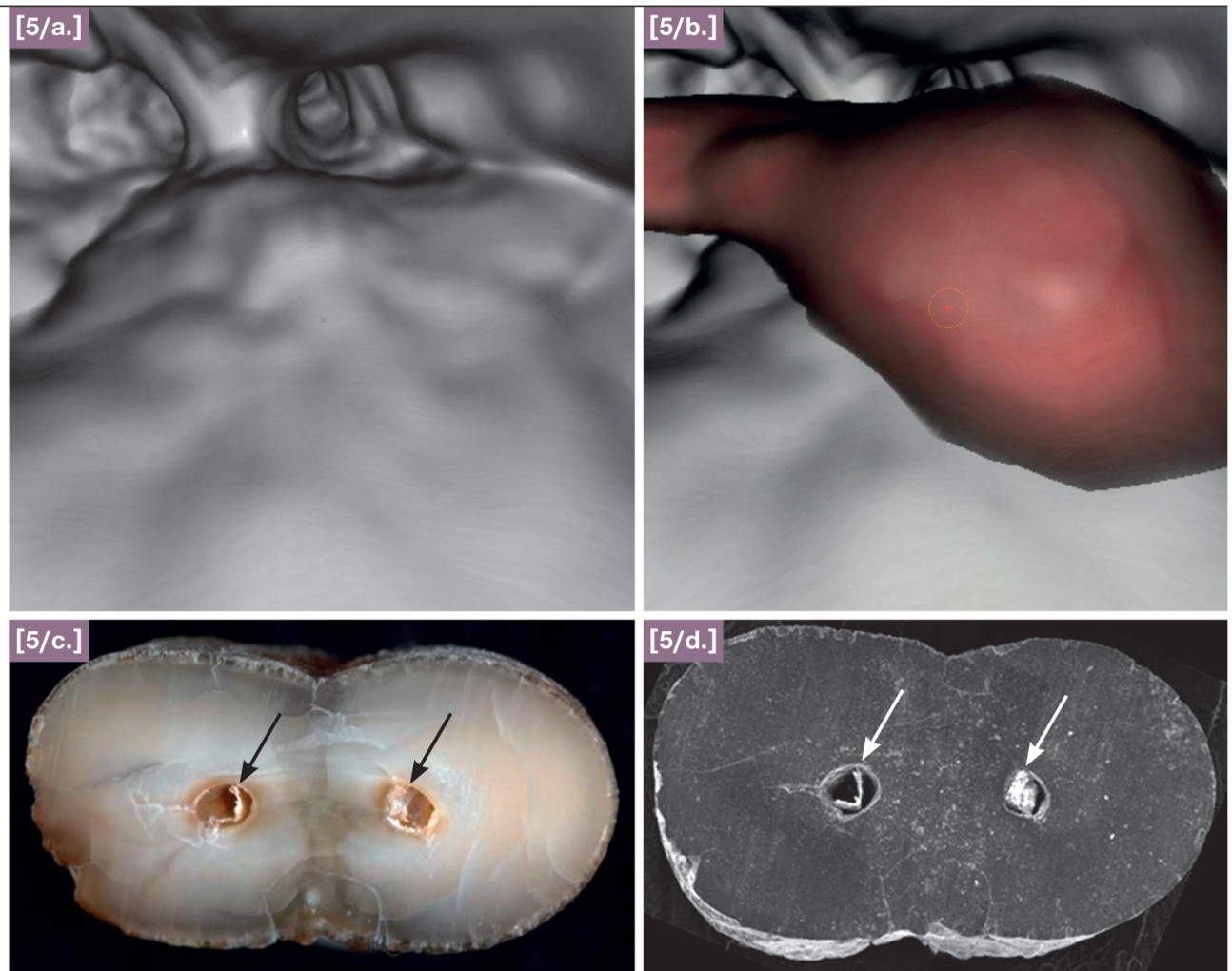

ruálhatóvá vált a fogbélüregben összeszáradt lágyszövet jelenléte és alakja. Ez a fog DVT-vizsgálatakor a már említett $0,2 \mathrm{~mm}$ es részletgazdag felbontással is párosult: így a felszínek megjelenítése során a virtuális endoszkópia használatával, mintegy a fog belsejében „sétálva” vált vizsgálhatóvá a pulpakamra üregrendszerében megmaradt és összeszáradt fogbél, azaz a fogat egykor tápláló erek és idegek maradványa ( $5 / a$. és 5/b. kép). Ép fogak fogbeléhez viszonylag nehezen jutnak el a baktériumok, így azok hosszú ideig megmaradhatnak DNS-mintavételre alkalmas állapotban, aminek fontos igazságügyi orvostani vonzatai vannak.

A DVT-technológia alkalmazása révén már vizsgálatunk elsố fázisában, a fog roncsolása nélkül képesek voltunk elvégezni a fogorvosi vonatkozású morfológiai és patológiai vizsgálatokat.

Vizsgálatunk második részében három, a hossztengelyre merőleges fogcsiszolat készült, melyeknek fényképei és az ezekrôl készített scanning elektromikroszkópos felvételek is igazolták a DVT-felvételen megjelenített összeszáradt fogbél (lágyszövet) jelenlétét ( $5 / c$. és 5/d. kép).

Vizsgálatunk harmadik részében energiadiszperzív röntgenspektometriával vizsgáltuk a felső kisőrlő fog, illetve a rajta talált fogkố részletét. A fog anyagának vizsgálata során kalcium és foszfor került kimutatás- ra. Utóbbi a foszfát alkotója, ez a kalciummal pedig a hidroxiapatit alkotóeleme, ami a dentin normál építőegysége. Kimutatásra került még kén és szén is, amelyek az aminosavak alkotóelemeiként fehérje jelenlétére utalnak. Ezek lokalizációja a pulpaûr volt, tehát a fogbél összeszáradt lágyszövete. A fogról eltávolított fogkố vizsgálata során kalcium mellett foszfor és nátrium is kimutatható volt, melyek a nyálból épültek be. Ahol viszont a fogkőmintából hiányzott a kalcium és a foszfor, ott a területet szén töltötte ki, mely szerves anyag, azaz ételmaradék maradványára utal.

A röntgenfluoreszcens elemanalízis során arzén jelenlétét a fogbélben nem sikerült kimutatni, így tehát Széchényi Pál arzénnel való megmérgezése egyértelmúen kizárható.
[5. kép] Az összeszáradt fogbélmaradvány jelenlétének képi dokumentálásai. A DVT-felvétel virtuális endoszkópia funkcióval történő vizsgálata lehetővé tette mintegy „,belülről nézve” a fogbél üregrendszerének 3D megjelenítését (5/a.), valamint az összeszáradt lágyszövet kiterjedésének és formájának az ábrázolását (5/b.). Az összeszáradt fogbél megjelenítésére a hagyományos röntgenfelvételek nem alkalmasak, de esetünkben a különálló fog DVT-vizsgálata során a fog szerkezetének roncsolása nélkül vált megjelenithetővé a fogban rejlő lágyszövetmaradvány. Mind az eltávolított fog gyökerének haránt irányú csiszolatáról készült fényképen (5/c.), mind a scanning elektromikroszkópos felvételen (5/d.) felismerhető a fogbél lágyszövetének összeszáradt maradványa (nyilakkal jelölve), igazolva a DVT-felvétel eredményeit. Plachtovics Márk (5/a., $5 /$ b.) és Kerényi Tibor (5/c., 5/d.) felvételei, 2010.

[6. kép] Széchényi Pál AP irányú koponyafelvétele. Kristóf Lilla Alida és Somogyi Andrea röntgenfelvétele, 2007. 
II 


\title{
The effect of calibration and detector temperature on the reconstructed cone beam computed tomography image quality: a study for the workflow of the iCAT Classic equipment
}

\author{
Mark Plachtovics, DMD, ${ }^{\mathrm{a}}$ Janos Goczan, DMD, ${ }^{\mathrm{b}}$ and Katalin Nagy, DDS, $\mathrm{PhD}^{\mathrm{c}}$ \\ Objective. The image quality of the reconstructed dental cone beam computed tomography (CBCT) acquisition is strongly \\ dependent on the characteristics of the applied detector. Some flat panel detector (FPD) types require a warming-up period \\ (WUP) to achieve a steady-state temperature; and some of them, those that have a cesium iodide detector, may require a \\ calibration process (CP) after each WUP. \\ Study Design. Quality-assurance phantom was used for the evaluation of image quality, including spatial accuracy and \\ density response with and without WUP and CP using iCAT Classic equipment. \\ Results. The correlation between the measured gray values and the multidetector computed tomography (MDCT) values \\ deviated slightly from linearity (defined by the 45-degree line). There was no detectable difference in the spatial accuracy of \\ the four different scanning modes. \\ Conclusions. Although the WUP is important to reach the required steady-state temperature, the CP has a greater effect on the \\ image quality. (Oral Surg Oral Med Oral Pathol Oral Radiol 2015; a:1-8)
}

The cone beam computed tomography (CBCT) imaging process consists of several steps (Figure 1). The quality of the image may be influenced by a number of effects during the signal conversion chain. One of these is the optimal or nonoptimal state of the detector. For example, some instruments that use a certain type of flat panel detector (FPD) may require a warming-up period (WUP) for the detector to reach its steady-state temperature. Also, in certain cases, a calibration process $(\mathrm{CP})$ of the FPD is recommended for obtaining the ideal image quality. This requirement may escape the attention of some technicians. Also, during an emergency in the oral surgery department, an acquisition may have to be taken immediately after starting the equipment. Consequently, it is of utmost importance to investigate the impact of the WUP and the CP of the FPDs on image quality; this paper will focus on this aspect. For instance, for the iCAT Classic equipment (Imaging Sciences International, Hatfield, PA), the WUP is about 2 hours from the cold state. ${ }^{1}$ After the WUP, an electric fan prevents overheating and maintains a steady-state temperature of $30{ }^{\circ} \mathrm{C}$ in the FPD. The detector system is analyzed during the

\footnotetext{
${ }^{a}$ Research Associate, Faculty of Dentistry, University of Szeged, Tisza Lajos krt 64, Szeged, 6720, Hungary.

${ }^{\mathrm{b}}$ Research Associate, Resolution Specialist Treatment Centre, Becket House, Hendford, Yeovil, BA20 1 TE, UK.

${ }^{\mathrm{c}}$ Professor, Faculty of Dentistry, University of Szeged, Tisza Lajos krt 64, Szeged, 6720, Hungary

Received for publication Aug 30, 2014; returned for revision Dec 2, 2014; accepted for publication Dec 9, 2014.

(C) 2015 Elsevier Inc. All rights reserved.

$2212-4403 / \$$ - see front matter

http://dx.doi.org/10.1016/j.000o.2014.12.009
}

$\mathrm{CP}$, and suitable correction data are derived and later used during subsequent image acquisition to compensate for known deviations from the ideal behavior of the detector (Figure 1). These modified data would serve as the database for the reconstructed volume of the image. $^{2}$ Consequently, for quality assessment, instead of judging the quality of the image projected on the detector, it is more practical to examine the quality of the reconstructed image. Eventually, it is this image that the clinician would examine, not the one directly put out by the detector. Assessment of image quality is best achieved by following the quality assurance protocol for the equipment.

The objective in the present in vitro study is to investigate the measured gray values and the spatial accuracy of a quality-assurance phantom on the reconstructed image, which is recommended by the manufacturer for quality assessment of the equipment. Figure 2 shows the applied setup of the qualityassurance phantom in the iCAT Classic dental CBCT equipment used.

\section{MATERIALS AND METHODS}

To investigate the effect of the detector temperature and that of the calibration process of the FPD on CBCT

\section{Statement of Clinical Relevance}

The clinical relevance of our work is that it would help clinicians obtain better density accuracies in their cone beam computer tomography reconstructed acquisitions. 


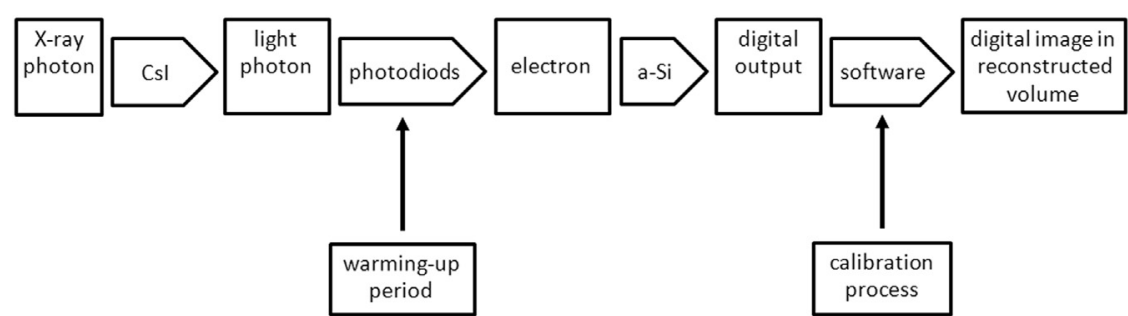

Fig. 1. Schematic figure of the signal conversion chain from $x$-ray to three-dimensional reconstructed image of the dental CBCT equipment, which incorporates an amorphous silicon image detector with a cesium iodide conversion layer. $C B C T$, cone beam computed tomography; $a$-Si, amorphous silicon; $C s I$, cesium iodide.

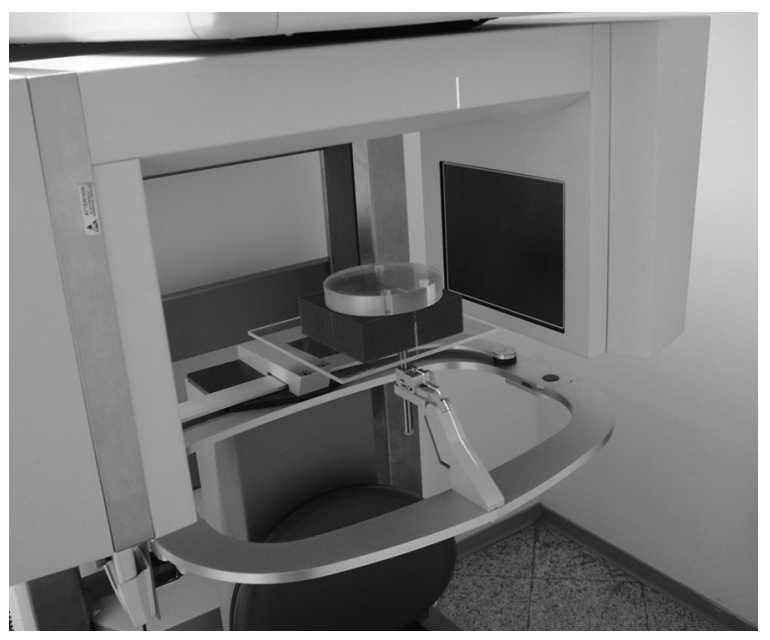

Fig. 2. Photograph of the configuration setup of the cylindrical (150-mm diameter) standard Imaging Sciences International (ISI) quality assurance CBCT phantoms in the iCAT Classic equipment. $C B C T$, cone beam computed tomography.

image quality, four different experimental conditions were used (Table I). Table II shows the technical parameters of these applied iCAT Classic CBCT scans. The iCAT Classic CBCT equipment is powered by the XoranCAT technology acquisition program, version 3.1.62 (Xoran Technologies Inc., Ann Arbor, MI). According to the operator's manual, ${ }^{1}$ all items were to be removed before calibrating the sensor, out of the field of view (FOV), and therefore these scans were taken without the head holder and chin rest of the instrument. The quality-assurance CBCT phantom was mounted horizontally, always in the same position in the center of the FOV on a foam layer (Figure 2). This Imaging Sciences International (ISI) phantom on the CBCT axial image is shown in Figure 3 and Figure 4. The image and location of the four insets are shown in Figure 3, and the appearance of the bar-pattern is shown in Figure 4. The quality assurance procedure would require two different measurements.
Table I. List and abbreviations of the four experimental conditions used for the flat panel detector (FPD) in the present study

\begin{tabular}{lc}
\hline Cold detector without calibration: & Cold detector with calibration: \\
COLD & COLD $+\mathrm{C}$ \\
Warm detector without & Warm detector with calibration: \\
calibration: WARM & WARM $+\mathrm{C}$ \\
\hline
\end{tabular}

$C O L D$, the acquisition was taken without warming-up period and calibration process of the FPD; $C O L D+C$, the abbreviation for the scan taken directly after the start of the equipment with cold detector but after the calibration process; WARM, indicates that the machine was on for at least 2 hours before the scan but no detector calibration was performed; WARM $+C$, scan protocol is consistent with the cone beam computed tomography scan with the complete calibration sequence after the warming-up period - the 2-hour warming-up period preceded the calibration process.

Table II. Performance characteristics for the applied acquisition mode of the iCAT Classic 14-bit gray-scale resolution CBCT dental imaging system*

\begin{tabular}{lc}
\hline Diameter of the FOV $(\mathrm{mm})$ & 154 \\
Height of the FOV $(\mathrm{mm})$ & 60 \\
Slice thickness of the reconstruction $(\mathrm{mm})$ & 0.2 \\
Reconstructed image matrix size (pixel) & $800 \times 800$ \\
Scan times (seconds) & 40 \\
Degrees of rotation & 360 degrees \\
Detector pixel height & 0.2540 \\
Tube current (mAs) & 36.12 \\
Tube voltage $(\mathrm{kVp})$ & 120 \\
\hline
\end{tabular}

$C B C T$, cone beam computed tomography; FOV, field of view.

*This acquisition mode is abbreviated as Maxl $6 \mathrm{~cm}, 40 \mathrm{Sec}, 0.2$ Voxel MaxRes.

First, the measured gray values in Hounsfield units were compared for the four different experimental conditions of the four homogenous density materials ${ }^{3,4}$ of the quality assurance CBCT phantom: Air $\left(1.29 \mathrm{~kg} / \mathrm{m}^{3}=\right.$ $\left.0.00129 \mathrm{~g} / \mathrm{cm}^{3}\right)$, low-density polyethylene (LDPE) $(0.92$ $\left.\mathrm{g} / \mathrm{cm}^{3}\right)$, acryl $\left(1.18 \mathrm{~g} / \mathrm{cm}^{3}\right)$ and Teflon $\left(2.16 \mathrm{~g} / \mathrm{cm}^{3}\right)$. On the basis of our previous results, ${ }^{4}$ no significant statistical variation was expected in this experiment when more scans were taken about the phantom with the same detector characteristics. For this reason, only one 

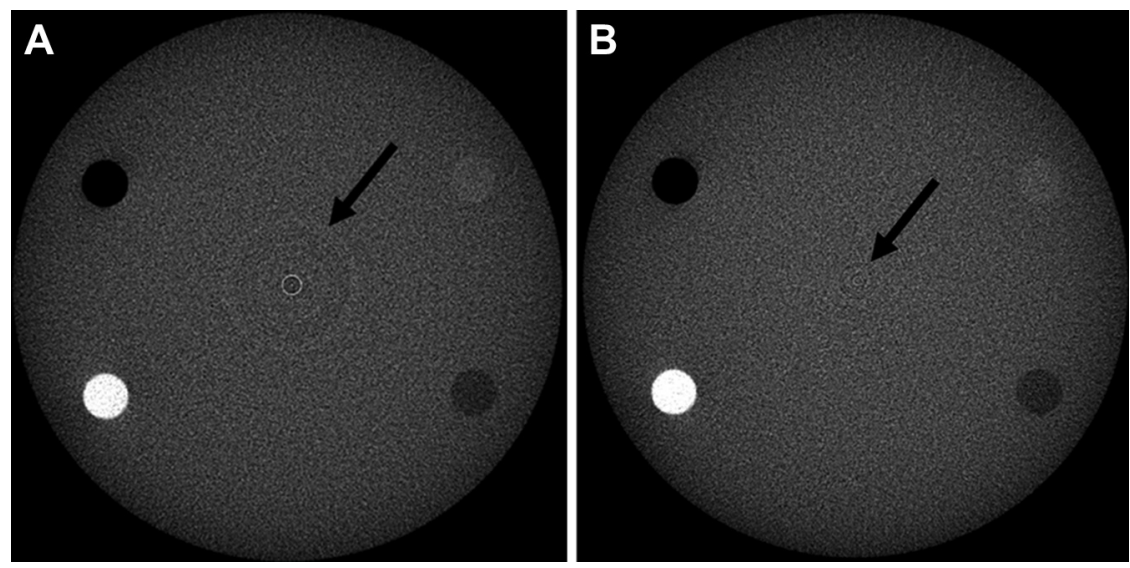

Fig. 3. Typical examples for ring artifacts in CBCT image which may result from failures of the calibration process (CP). Reconstructed images of the $150-\mathrm{mm}$ diameter standard ISI quality assurance phantom, which is made of air $\left(1.29 \mathrm{~kg} / \mathrm{m}^{3}=\right.$ $\left.0.00129 \mathrm{~g} / \mathrm{cm}^{3}\right)$, LDPE $\left(0.92 \mathrm{~g} / \mathrm{cm}^{3}\right)$, acryl $\left(1.18 \mathrm{~g} / \mathrm{cm}^{3}\right)$ and Teflon $\left(2.16 \mathrm{~g} / \mathrm{cm}^{3}\right)$ embedded in a Plexiglas cylinder. In the height of these two axial slices, the bar pattern phantom is not visible. On both of these acquisitions, ring artifacts are detectable (arrows) because these scans were taken without the $\mathrm{CP}$ of the detector. A, COLD. B, WARM. Properties for these experimental conditions of the applied acquisitions chosen for this study are shown in Table I. The four inserts are arranged in the following sequence: upper left hand side, air; lower left hand side, Teflon; lower right hand side, LDPE; upper right hand side, acryl. (Window 3000, level 605, applied filtering: "Sharpen $3 \times 3$ " by XoranCAT technology acquisition program, version 3.1.62 [Xoran Technologies Inc., Ann Arbor, MI]). CBCT, cone beam computed tomography; LDPE, low-density polyethylene.

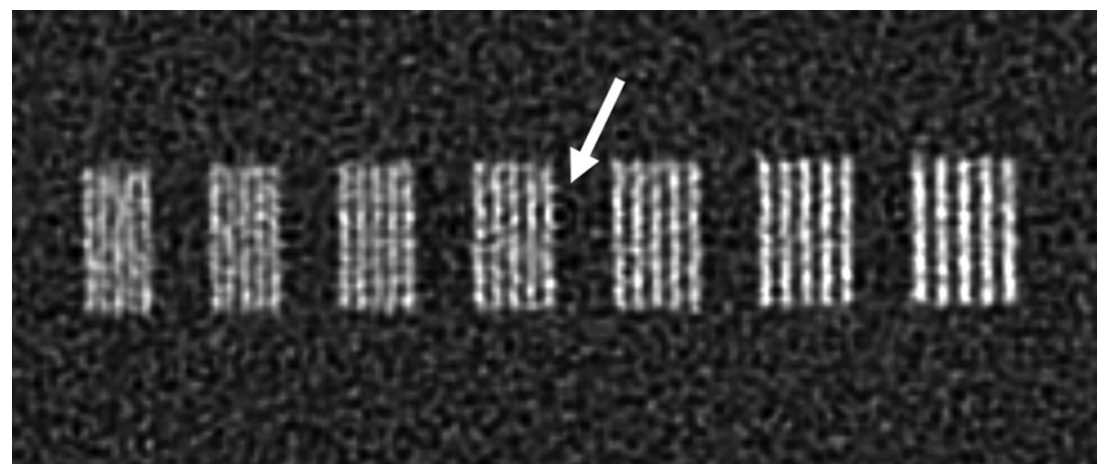

Fig. 4. Spatial resolution in the axial slice by cold detector without the CP (COLD). There were no visible differences in the appearance of the bar pattern phantom in the four applied scan conditions (Table I). The only detectable discrepancy from the other three experiential scan protocols, this ring artifact on the center of the axial views (arrow), was by the COLD operation mode. For better visibility, a slightly different setting was used: Window 3000, level 605, applied filtering: "Sharpen $3 \times 3$ ” by XoranCAT technology acquisition program, version 3.1.62.

experiment was performed using 10 different slice measurements that were properly averaged. The reconstructed volume was exported into the iCATVision software program, version 1.6.2.0. (Imaging Sciences International, Hatfield, PA). The gray values of the four 12-mm diameter uniformdensity cylinders (air, LDPE, acryl, and Teflon) were analyzed within a $60.2-\mathrm{mm}^{2}$ square-type region of interest. Ten different slices in the axial planes were investigated along the axial axis from the upper part of the phantom toward the lower region. To avoid distortion of the measured gray values, these analyzed axial slices were always chosen in such a way that they were not situated within the level of the "line par center" or the cone beam artefact. ${ }^{5}$ The average of these 10 values was calculated, and the standard deviation (SD) was determined. These average values of the four inserts were correlated with the multidetector computed tomography (MDCT) measured values (General Electric Medical Systems LightSpeed VFX Ultra, Tokyo, Japan, 120 kilovolt peak, $144.91 \mathrm{mAs}$ ) as described previously. ${ }^{4}$ The MDCT value is the expected CT number measured for the same ISI quality assurance phantom (Table III). ${ }^{4}$

Second, for checking the spatial accuracy of the CBCT images in the four applied scan conditions, the 
Table III. The expected CT numbers in Hounsfield units of four different phantom materials

\begin{tabular}{lr}
\hline & $M D C T$ \\
\hline Air & -999.24 \\
LDPE & -104.10 \\
Acryl & 115.16 \\
Teflon & 965.94 \\
\hline
\end{tabular}

$C T$, computed tomography; $M D C T$, multidetector computed tomography; $L D P E$, low-density polyethylene.

From Plachtovics M, Bujtar P, Nagy K, Mommaerts MY. Highquality image acquisition by double exposure overlap in cone beam computed tomography. Oral Surg Oral Med Oral Pathol Oral Radiol. 2014;117:760-767.

visibility of the bar pattern at the center of the ISI quality assurance phantom was investigated. These axial images, at the center of the height in the phantom, were analyzed by the XoranCAT technology acquisition program at the maximum magnification. The "Angio_Sharpen_high $5 \times 5$ " image filter was applied, and the set of the window level was $400 / 1000$, as mentioned in the iCAT Classic operator's manual. ${ }^{1}$ These images from all four different applied experimental modalities were investigated on the same monitor (EIZO FlexScan L887 $51 \mathrm{~cm}$ (20.1 inch) class color LCD monitor, EIZO NANAO Corp., Matto, Japan).

\section{RESULTS}

Small changes in the gray values of the four inserts of the quality assurance phantom can be detected on the reconstructed CBCT image with the use or the omission of the appropriate $\mathrm{CP}$ and with alteration of the detector temperature. The measured gray values of the four inserts within the ISI quality assurance Plexiglas phantom are listed in Table IV. The averages and their SDs are shown in the last two lines of the same table (Table IV). The four experimental conditions resulted in four different patterns, as shown in the four curves in Figure 5, in which the $\mathrm{x}$-axis represents the expected $\mathrm{CT}$ numbers (in $\mathrm{HU}$ ), as summarized in Table III. It should be emphasized that in the case of WARM $+\mathrm{C}$ condition the deviation from the expected $\mathrm{CT}$ numbers (in $\mathrm{HU}$ ) and the measured gray values (in $\mathrm{HU}$ ) differ the least in the case of air and Teflon material, of which the latter is of similar density to cortical bone (Table V). In contrast to the above, in the case of inserts equivalent to the density of soft tissue, such as LDPE, and the inserts equivalent to the density of spongious bone, such as acryl, the cold sensor gave more accurate results but only with calibration $(\mathrm{COLD}+\mathrm{C})$. Air, the single insert material, showed more accurate mean values $(\mathrm{WARM}+\mathrm{C}, \mathrm{WARM}$ and COLD $+\mathrm{C}$ ) than MDCT value $(-999.24 \mathrm{HU})$. Furthermore, each of the 10

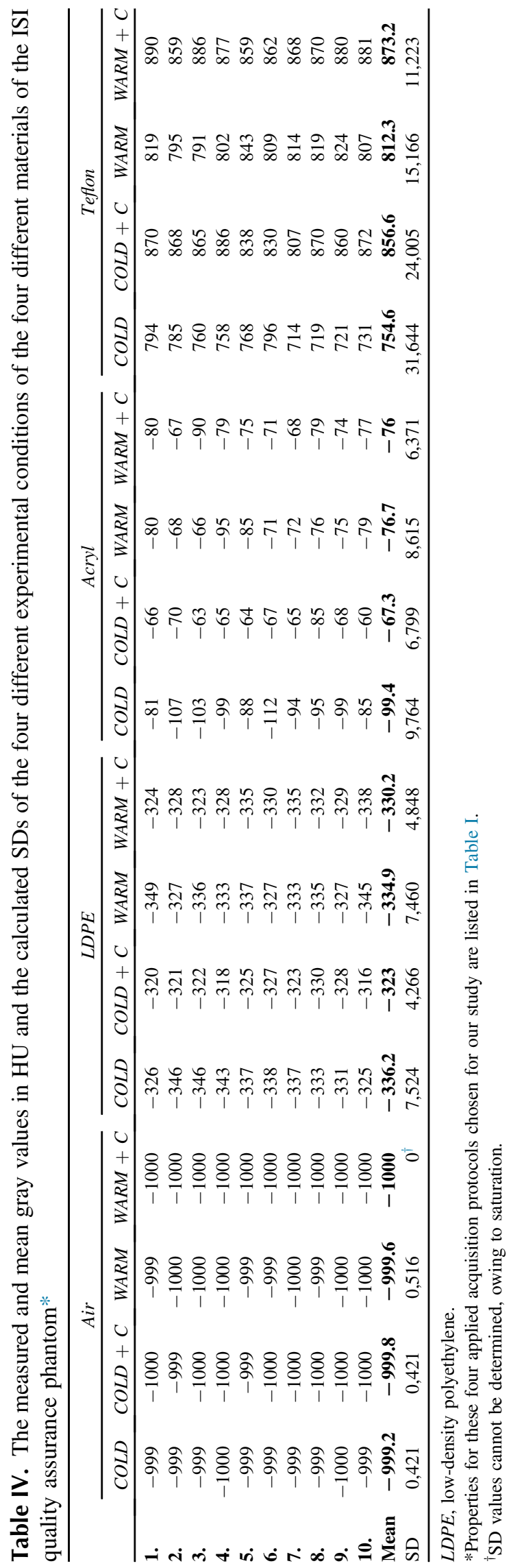




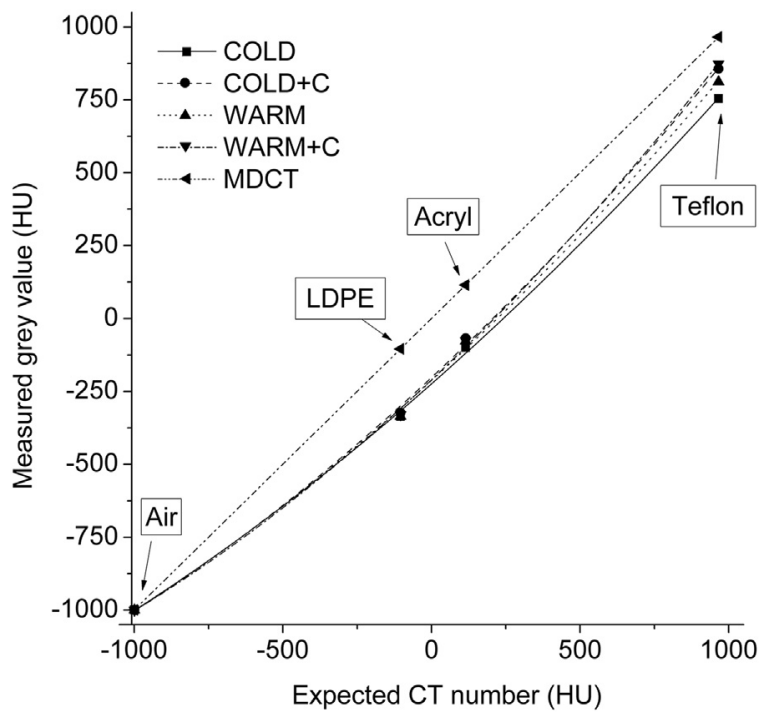

Fig. 5. The 45-degree straight line corresponds to perfect correlation, which is $\mathrm{Y}=\mathrm{X}$, where both variables are the multidetector computed tomography (MDCT) values (expected CT number in HU). Fitted quadratic equations of the four inserts of the quality assurance phantom are for the four experimental conditions of the acquisition protocol. The measured gray values correlated with the MDCT expected HU values slightly parabolically, and in the case of Teflon almost reached the perfect correlation (defined by the 45-degree line). Fitting parameters are summarized in Table VI. The measured data are listed in Table V. The expected CT numbers in HU are given in Table III. LDPE, low-density polyethylene; $M D C T$, multidetector computed tomography; $H U$, Hounsfield units.

measured gray values for the air insert were uniform $(-1000 \mathrm{HU})$ in the case of the applied WARM $+\mathrm{C}$ experimental condition.

During analysis of the spatial accuracy in the CBCT images of the four applied scan conditions, no difference was observed in visibility at the line par center. There was only one curious discrepancy in COLD operation mode. This involved projection of the concentric circles of ring artefacts on the bar pattern phantom, but it did not influence the resolution of the image (Figure 4).

\section{DISCUSSION}

During the past several years, the literature has included many reports in which different types of CBCT equipment were compared, ${ }^{6-11}$ with interesting results. However, some rather important characteristics of these instruments might have escaped the focus of scientific interest so far. The differences in the performances of the instruments described in this paper are related to the workflow of the acquisition procedure. Routine dental radiography, used more and more frequently, is increasing the radiation exposure of patients. The use of
Table V. Mean gray values (Y)*

\begin{tabular}{lrcrcr}
\hline & COLD & COLD $+C$ & WARM & WARM $+C$ & MDCT $^{4}$ \\
\hline Air & -999.2 & -999.8 & -999.6 & -1000 & -999.24 \\
Acryl & -99.4 & -67.3 & -76.7 & -76 & 115.16 \\
LDPE & -336.2 & -323 & -334.9 & -330.2 & -104.10 \\
Teflon & 754.6 & 856.6 & 812.3 & 873.2 & 965.94 \\
\hline
\end{tabular}

Properties for applied acquisition protocols chosen for this study are in Table I.

$M D C T$, multidetector computed tomography; LDPE, low-density polyethylene.

*Quadratic regression was used to establish the relationship between the measured gray values $(\mathrm{Y})$ and expected computed tomography (CT) numbers (Table III) of the four inserts: $\mathrm{Y}=\mathrm{AX}+\mathrm{BX}^{2}+\mathrm{C}$, where both $\mathrm{X}$ and $\mathrm{Y}$ are measured in Hounsfield units.

From Plachtovics M, Bujtar P, Nagy K, Mommaerts MY. Highquality image acquisition by double exposure overlap in cone beam computed tomography. Oral Surg Oral Med Oral Pathol Oral Radiol. 2014;117:760-767.

Table VI. Coefficients (A, B, and C) of the fitted quadratic equation for the four experimental conditions of the acquisition protocol

\begin{tabular}{lccc}
\hline \multicolumn{1}{c}{ Code } & $A$ & $B$ & $C$ \\
\hline COLD & 0.899 & $1.212 \times 10^{-4}$ & -224.33 \\
COLD + C & 0.952 & $1.519 \times 10^{-4}$ & -202.37 \\
WARM & 0.930 & $1.395 \times 10^{-4}$ & -212.76 \\
WARM + C & 0.961 & $1.691 \times 10^{-4}$ & -210.56 \\
\hline
\end{tabular}

Quadratic regression was used to establish the relationship between the measured gray values $(\mathrm{Y})$ and expected computed tomography (CT) numbers $(\mathrm{X})$ of the four inserts: $\mathrm{Y}=\mathrm{AX}+\mathrm{BX}^{2}+\mathrm{C}$, where both $\mathrm{X}$ and $\mathrm{Y}$ measured in Hounsfield units.

Properties for applied acquisition protocols chosen for this study are in Table I.

CBCT imaging has resulted in higher doses of radiation compared with other traditional dental radiographic methods. ${ }^{12-15}$ The overall amount of radiation doses to patients has increased. In accordance with the as-lowas-reasonably-achievable (ALARA) principle, the radiation dose for dental patients should be optimized to achieve the lowest practical level to meet the requirements of a specific clinical situation. ${ }^{14}$ Consequently, operators who are using CBCT units with operator-adjustable exposure settings should understand that these parameters affect both image quality and radiation dose; therefore, careful selection is required to follow the ALARA principle. ${ }^{2,14}$ For this reason, it is important that the best image quality be obtained at a certain radiation level. Molteni ${ }^{16}$ pointed out the importance of the application of imagespecific calibration of the equipment. However, in the case of certain types of equipment, the use of this extra step in the procedure could also result in less-thanperfect gray values. In accordance with the Journal of the American Dental Association (JADA) statement, ${ }^{14}$ 
it was possible in the present study to apply the quality control program recommended by the manufacturer. "Staffs of facilities using CBCT should establish a quality control program. This program can be based on the manufacturer's recommendations or can be established, implemented, and monitored by a qualified expert." 14

The present work aimed to assess image quality by examining the reconstructed volume. This has been achieved by the use of the bar pattern phantom and of the four inserts (air, LDPE, acryl, and Teflon) of the manufacturer's quality assurance phantoms.

The iCAT Classic equipment has a flat panel, which incorporates an amorphous silicon image detector with a cesium iodide conversion layer. This is a part of a complete digital x-ray imaging system (PaxScan 2520 Digital Imaging System, produced by Varian Medical Systems Inc., Salt Lake City, UT), which consists of the PaxScan the 2520 receptor, a command processor, and the power supply. This iCAT Classic CBCT instrument is claimed to work between 10 and $35^{\circ} \mathrm{C}$. ${ }^{1}$ The cesium iodide solid-state amorphous silicon FPD is an indirect, two-step x-ray conversion system. ${ }^{2,17,18}$ This two-step detection is based on the electronic signal generation from x-ray photons, which are not absorbed by the target. The first step is the conversion of the x-ray to visible light. When $\mathrm{x}$-ray photons strike the scintillator screen of the FPD, visible photons are emitted from the incorporated cesium iodide substrate. In the next step of the signal conversation chain, this visible light is converted by the pin photodiodes to electric charge, ${ }^{17,19}$ which is collected by the integrating amplifier and converted to output signal voltage, leading to digital data (Figure 1). ${ }^{18}$ The resistance characteristic of each of the photodiodes of the FPD depends on the temperature; this is why it is important to reach the steady-state temperature of the FPD during the WUP. The other important factor is the calibration process. Consequently, homogenous $\mathrm{x}$-ray illumination, without any objects interfering with this radiation, is best for testing the detector and identifying pixel defects that show different gray shades. This CP is performed in four steps: (1) analysis of the detector panel; (2) offset calibration; (3) gain calibration; (4) high-gain calibration.

Two types of iCAT Classic equipment operation require WUP. One is a 5-second-long WUP of the x-ray tube, which is needed to ensure homogeneous radiation during gain and high-gain calibration. These last two steps of the $\mathrm{CP}$ always start with this 5-second exposure without $\mathrm{x}$-ray detection to ensure the warming up of the $\mathrm{x}$-ray tube. ${ }^{1}$ Following this, gain and high-gain calibrations are performed with homogeneous radiation, which is necessary to achieve uniform illumination to every pixel of the FPD.
The second type of operation requiring WUP of the iCAT Classic equipment is the WUP of the FDP, which lasts for 2 hours. This process has been described in some detail in this paper. The output electric charge of the photodiodes in the FDP can fluctuate even in the case of uniform photon density. This fixed pattern noise would affect the density response quality of the FPD. Although the $\mathrm{x}$-ray radiation is homogeneous and the FDP has reached the steady-state temperature, some pixels of the FPD will still show different shades. These would appear as lighter or darker ring artefacts ${ }^{20}$ around the axis of the rotation on the reconstructed image. The ring shape is created by the rotating motion of the detector during acquisition (Figures 3 and 4).The steady-state temperature of the FDP is not enough to prevent such a variable density response. The abovementioned four-step $\mathrm{CP}$ is also required, as it guarantees the optimal dose response of FPD pixels. The information gathered in this way would be used during the reconstruction process to compensate the differences in photodiode output (Figure 1). ${ }^{2}$

Of the measurements from the four inserts, only the air and Teflon measurements supported the conclusion that both the WUP and the CP are essential to achieve ideal density response in the reconstructed images. However, this is not contradictory, since dental CBCT technology can enable visualization of the high-contrast structure $^{17}$ in the acquisition, similar to MDCT for the "bone window" range. ${ }^{21}$ The numerical data of the Teflon insert indicate that the WUP and subsequently the $\mathrm{CP}$ are absolutely necessary for higher-density objects. According to the literature, ${ }^{5,17,21}$ CBCT technology is designed for relatively higher-density materials; therefore, lower-density materials such as fine trabecular bone, D $4^{16}$ (corresponding to acryl), or soft tissues that are mimicked by LDPE cannot be studied quantitatively by this method while using this equipment. ${ }^{4,13}$

It is interesting to note that the four fitted quadratic curves of the four sets of measurements are below the ideal 45-degree line (Figure 5), which corresponds to the perfect correlation (Table V). However, if we were extrapolating the data to materials of higher density than Teflon, such as metallic dental implants, the quadratic curves would cross over the ideal 45-degree line. Note that the fitted function shown by Figure 5 corresponds very well to the MDCT value of air $(-999.24 \mathrm{HU})$ and is reasonably accurate for that of the Teflon (+965.94 HU). However, the deviation is the largest for LDPE and acryl (in the order of magnitude of $200 \mathrm{HU}),{ }^{4}$ which are near the mid-point $(0,0)$ of the fitted curve. In accordance with the above, the numerical data obtained for air and Teflon (Table IV) indicate that the CP is absolutely necessary. 
Returning to the fundamental question of accuracy, it has to be emphasized that the accuracy of this in vitro study was dependent on the selection of the 10 different slices that were investigated. The choices for the 10 different slices along the axial axis were very difficult and had to be made with great care. This extra care was necessary because either the presence within the same level of the cone beam artefact ${ }^{2,3,5,10,16,19}$ or that of the "line par center" $, 5,7$ would cause distortions of the gray values of the four inserts. Therefore, these slices were not considered appropriate for the density response examination.

The appearance of concentric circles in the reconstructed image of a well-functioning CBCT instrument is an indication that the CP with or without the WUP is incomplete. The appearance of these ring artefacts is the sign of pixel defects ${ }^{2,20}$ caused by the differences in the density responses of the pixels of the FPD. Therefore, it is beneficial to use homogeneous higher-density inserts that contain the quality assurance phantom, since an inhomogeneous structure, such as variably structured bones of inhomogeneous density, would cover the pixel defects.

\section{CONCLUSIONS}

The use of higher-density homogeneous insert materials, such as Teflon, in the quality assurance phantom proves the need for the WUP and subsequently the $\mathrm{CP}$ in certain types of FPD. The data obtained by the air insert has also supported this observation because the value $(-1000 \mathrm{HU})$, as set by the definition, was reached gradually during the COLD, WARM, $\mathrm{COLD}+\mathrm{C}$, and WARM $+\mathrm{C}$ experiment conditions. In contrast to this, homogeneous materials with lower density than Teflon, such as acryl and LDPE, do not mimic the density range of compact bone; therefore, they are not ideal to investigate the density response of this dental CBCT (Figure 5). Furthermore, it appears from the data obtained from the higherdensity objects that the effect of the WUP is noticeable, but the effect of the $\mathrm{CP}$ is more significant (Table IV). Consequently, both cold and warm detectors are useful, but only with appropriate calibration. From this, we may conclude that in the standardization of CBCT instruments that use the same or a similar type of FPD, both the WUP and the $\mathrm{CP}$ are important factors. However, the $\mathrm{CP}$ is considerably more important than the WUP for the FPD in preparing images of comparable quality with a fixed radiation dosage; therefore, these steps should be performed even in exceptional cases when the FPD has not had enough time to reach the steady-state temperature.

\section{REFERENCES}

1. iCAT Classic Operator's Manual. Hatfield, PA: Imaging Sciences International; 2010.

2. Scarfe WC, Farman AG. Cone-beam computed tomography: volume acquisition. In: Stuart CW, Michael JP, eds. Oral Radiology: Principles and Interpretation. St. Louis, MO: Mosby; 2014:185-198.

3. Bryant JA, Drage NA, Richmond S. Study of the scan uniformity from an iCAT cone beam computed tomography dental imaging system. Dentomaxillofac Radiol. 2008;37: 365-374.

4. Plachtovics M, Bujtar P, Nagy K, Mommaerts MY. High-quality image acquisition by double exposure overlap in cone beam computed tomography. Oral Surg Oral Med Oral Pathol Oral Radiol. 2014;117:760-767.

5. Pauwels R, Stamatakis H, Manousaridis G, et al. Development and applicability of a quality-control phantom for dental conebeam CT. J Appl Clin Med Phys. 2011;12:245-260.

6. Liang X, Jacobs R, Hassan B, et al. A comparative evaluation of cone beam computed tomography (CBCT) and multi-slice CT (MSCT) Part I. On subjective image quality. Eur J Radiol. 2010;75:265-269.

7. Pauwels R, Nackaerts O, Bellaiche N, et al. SEDENTEXCT Project Consortium. Variability of dental cone beam CT grey values for density estimations. $\mathrm{Br} J$ Radiol. 2013;86: 20120135.

8. Nemtoi A, Czink C, Haba D, Gahleitner A. Cone beam CT: a current overview of devices. Dentomaxillofac Radiol. 2013;42: 20120443.

9. De Vos W, Casselman J, Swennen GR. Cone-beam computerized tomography (CBCT) imaging of the oral and maxillofacial region: a systematic review of the literature. Int J Oral Maxillofac Surg. 2009;38:609-625.

10. Nackaerts O, Maes F, Yan H, Couto Souza P, Pauwels R, Jacobs R. Analysis of intensity variability in multislice and cone beam computed tomography. Clin Oral Implants Res. 2011;22: 873-879.

11. Oliveira ML, Tosoni GM, Lindsey DH, Mendoza K, Tetradis S, Mallya SM. Influence of anatomic location on CT numbers in cone beam computed tomography. Oral Surg Oral Med Oral Pathol Oral Radiol. 2013;115:558-564.

12. Horner K, Islam M, Flygare L, Tsiklakis K, Whaites E. Basic principles for use of dental cone beam computed tomography: consensus guidelines of the European Academy of Dental and Maxillofacial Radiology. Dentomaxillofac Radiol. 2009;38: 187-195.

13. Tyndall DA, Price JB, Tetradis S, Ganz SD, Hildebolt C, Scarfe WC. Position statement of the American Academy of Oral and Maxillofacial Radiology on selection criteria for the use of radiology in dental implantology with emphasis on cone beam computed tomography. Oral Surg Oral Med Oral Pathol Oral Radiol. 2012;113:817-826.

14. The American Dental Association Council on Scientific Affairs. The use of cone-beam computed tomography in dentistry. An advisory statement from the American Dental Association Council on Scientific Affairs. J Am Dent Assoc. 2012;143: 899-902.

15. The SEDENTEXCT Project. Radiation protection: cone beam CT for dental and maxillofacial radiology. Evidence based guidelines. Geneva, Switzerland: European Commission: 2011. Available at: http://wwwsedentexcteu/guidelines

16. Molteni R. Prospects and challenges of rendering tissue density in Hounsfield units for cone beam computed tomography. Oral Surg Oral Med Oral Pathol Oral Radiol. 2013;116:105-119. 
17. Miracle AC, Mukherji SK. Cone beam CT of the head and neck, part 1: physical principles. Am J Neuroradiol. 2009;30: 1088-1095.

18. Chotas HG, Dobbins JT, Ravin CE. Principles of digital radiography with large-area, electronically readable detectors: a review of the Basics. Radiology. 1999;210:595-599.

19. Kalender WA, Kyriakou Y. Flat-detector computed tomography (FD-CT). Eur Radiol. 2007;17:2767-2779.

20. Schulze R, Heil U, Groß D, et al. Artefacts in CBCT: a review. Dentomaxillofac Radiol. 2011;40:265-273.

21. Schulze D, Blessmann M, Pohlenz P, Wagner KW, Heiland M. Diagnostic criteria for the detection of mandibular osteomyelitis using cone-beam computed tomography. Dentomaxillofac Radiol. 2006;35:232-235.

Reprint requests:

Mark Plachtovics, DMD

Faculty of Dentistry

University of Szeged

Tisza Lajos krt 64

Szeged, 6720

Hungary

Plachtovics.mark@stoma.szote.u-szeged.hu or placmark@gmail.com 
III 


\section{DECLARATION}

I am glad to declare that Dr. Mark Plachtovics may use, in his $\mathrm{Ph} . \mathrm{D}$. Dissertation, our joint paper entitled:

Intraosseous territory of the facial artery in the maxilla and anterior mandible: Implications for allotransplantation*

published in Journal of Cranio-Maxillo-Facial Surgery

This anatomical study, which was published in the above paper, was to define the intraosseous vascular territory (angiosomes) of the facial artery. The question was whether it is possible, considering all the benefits, to use the so-called dental CBCT scan for the examination of this vascular system.

The following quotations are from published paper concerning the method used.

"The artery was injected with a barium sulfate/xanthan gum suspension (Microtrast, Guerbet Gmbh, Sulzbach, Germany) in a gentle, pulsatilemanner. Two milliliters of Microtrast, diluted with 8 ml tap water, was used in each head."

"Cone-beam computed tomography $(C B C T)$ scans were taken with iCAT Classic (Imaging Sciences International, Hatfield, USA) from the 10 mandibular and maxillary segments. The slice thickness was $0.2 \mathrm{~mm}$."

The above method for our joint paper was developed by Dr. Mark Plachtovics.

The aim of his method oriented study was to find a scanning protocol and contrast material concentration for dental CBCT to make a setup for 3D mapping of the angiosomes of the face. It was important for him to find the contrast material concentration range to differentiate the compact surface of the bone from the entering vessels through the nutritive foramina, but to reduce the artefacts. With his established procedure it was possible to minimize the presence of artefacts. For this reason, a special calibration process was developed by him varying different contrast material concentrations in order to achieve the maximal visibility of the contrast material filled vessels in soft tissues and bone. It was also necessary for him to create a special phantom to model both for the cadaver heads and the blocks instead of performing a real anatomical examination. For his preliminary study, contrast material filled plastic tubes were used in these phantoms during the dental CBCT acquisitions. The advantage of using these phantoms created the possibility to make several series of measurements using different concentrations of various types of contrast materials.

On the basis of his preliminary study a predetermined concentration of the Microtrast contrast material solution (Microtrast, Guerbet $\mathrm{GmbH}$, Sulzbach, Germany) was used in the anatomical study of filled vessels.

All of these methods development work was carried out by Dr. Mark Plachtovics. Without the development such a method the above paper could not be publish. This paper appears as Paper $\mathbf{3}$ in Thesis $\mathrm{N}^{\circ} 5$ in the dissertation of Dr. Mark Plachtovics.

I have not used and will not use in the future Dr. Plachtovics research work for any $\mathrm{PhD}$ dissertation which appeared in our joint paper as quoted above.

20 March 2015

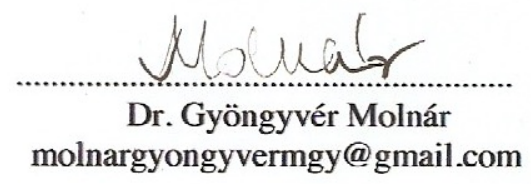

* Molnar G, Plachtovics M, Baksa G, Patonay L, Mommaerts MY. Intraosseous territory of the facial artery in the maxilla and anterior mandible: Implications for allotransplantation. $J$ Craniomaxillofac Surg. 2012;(40)180-184. DOI: 10.1016/j.jcms.2011.03.019. 


\title{
Intraosseous territory of the facial artery in the maxilla and anterior mandible: Implications for allotransplantation ${ }^{\text {is }}$
}

\author{
Gyongyver Molnar ${ }^{\mathrm{a}}$, Mark Plachtovics ${ }^{\mathrm{b}}$, Gabor Baksa ${ }^{\mathrm{a}}$, Lajos Patonay ${ }^{\mathrm{a}}$, Maurice Y. Mommaerts ${ }^{\mathrm{c}, *}$ \\ ${ }^{a}$ Department of Anatomy Histology and Embryology, Semmelweis University, Budapest, Hungary \\ ${ }^{\mathrm{b}}$ Kreativ Dental, Budapest, Hungary \\ ${ }^{\mathrm{C}}$ Division of Maxillo-Facial Surgery, Department of Surgery and Diagnosis, GH St. Jan Bruges-Ostend, Belgium
}

\section{A R T I C L E I N F O}

\section{Article history:}

Paper received 17 December 2010

Accepted 1 March 2011

\section{Keywords:}

blood supply

maxilla

chin

cone-beam Computed Tomography

facial Transplantation

\begin{abstract}
A B S T R A C T
Aim: The aim of this anatomical study was to define the intraosseous vascular territory of the facial artery. The clinical issue is whether ipsilateral facial artery anastomosis will guarantee blood supply to the ipsi- and contralateral mandibular symphyses and maxillae in allotransplantation.

Material and methods: Of 10 human cadaveric heads, the left facial artery was injected with a positive contrast agent. The maxillae and mandibular symphyses were investigated with cone-beam computed tomography (CBCT).

Results: Each ipsilateral maxilla and mandibular bone segment showed contrast medium in the intraosseous vessels. In $50 \%$ of cases, this was also the case on the contralateral side of the maxilla and anterior mandible.

Conclusions: The maxillae and the mandibular symphyses receive ipsilateral blood supply from the facial artery and, in $50 \%$ of cases, also from the contralateral facial artery. Internal maxillary artery anastomosis is not required for a vascularized maxillary bone flap. Additionally, involvement of the submental artery is not needed for a mandibular symphyseal bone flap.
\end{abstract}

(c) 2011 European Association for Cranio-Maxillo-Facial Surgery.

\section{Introduction}

Indications for transplanted composite tissue flaps are increasing in general (Pomahac and Aflaki, 2010), and currently, 12 more cases of facial allotransplantation have been reported since the first case of Devauchelle and Dubernard in 2005. The vascular delta, which is opened by arterial anastomosis, greatly determines the survival of the (partial) face allotransplant. Maxillo-facial reconstruction raises the issue of blood supply to the bone.

Lengelé (2009) advises transplanting the Type I/B flap (with the anterior mandible) on bilateral external carotid artery pedicles and the Type II/B (with the anterior maxilla) on bilateral, facial artery pedicles for good perfusion. Banks et al. (2009) recommend bilateral anastamosis to the external carotid arteries for bilateral or full maxillary bone replacement.

\footnotetext{
S Presented in part at the XXth Congress of the European Association for CranioMaxillo-Facial Surgery in Bruges, Belgium.

*Corresponding author. Division of Maxillo-Facial Surgery - Facial Transplantation Programme, AZ St. Jan Brugge-Ostend av, Ruddershove 10, B-8000 Brugge, Belgium. Tel.: +32 504522 60; fax: +32 50452279 .

E-mail address: maurice.mommaerts@azbrugge.be (M.Y. Mommaerts).
}

The issue is whether a single facial artery, retrieved distally to the submental artery, will guarantee blood supply to the ipsilateral mandibular symphysis and to the contralateral maxilla and mandibular symphysis, thus facilitating maxillo-facial allotransplantation. From a physiological point of view, at least on one side, the facial artery should receive the anastamosis, as bilateral, external carotid artery anastomosis would cut off the blood supply to both the lateral face and upper neck.

\section{Materials and Methods}

Ten fresh cadavers (five males, aged $37-85$ years, and five females, aged $45-75$ years) were warmed to room temperature. The left facial artery was dissected at the level of the mandibular border (Fig. 1), flushed with saline, and drained of blood. Cannulation was made with a 22-G cathether (Vasofix Braunüle, B. Braun AG Melsungen, Germany). The artery was injected with a barium sulfate/ xanthan gum suspension (Microtrast, Guerbet Gmbh, Sulzbach, Germany) in a gentle, pulsatile manner. Two milliliters of Microtrast, diluted with $8 \mathrm{ml}$ tap water, was used in each head. Successful injection was confirmed by whitish vessel staining in the oral mucous membrane. Cannulation of the facial artery distal to the submental artery implies that the symphysis is supplied neither by the inferior 
alveolar artery nor by the submental artery and that the maxilla is supplied neither by the internal maxillary artery nor the ascending palatine artery.

Osteotomies, approximately at the level of Le Fort II and behind the symphysis, were performed to detach the maxillae and the bony chin with minimal soft tissue coverage.

Cone-beam computed tomography (CBCT) scans were taken with iCAT Classic (Imaging Sciences International, Hatfield, USA) from the 10 mandibular and maxillary segments. The slice thickness was $0.2 \mathrm{~mm}$.

\section{Results}

On the CBCT scans, each ipsilateral maxilla and mandibular symphysis had intraosseous vessels revealed by the contrast material (Figs. 2-4). In half of the cases, the contralateral maxilla and mandibular symphysis also showed contrast-radiating endosseal vessels (Figs. 5 and 6). The blood supply of the bone had two sources: one through the neurovascular foramina (e.g., mental, infraorbital, and incisive) and one through the nutrient foramina.

In eight of the cases, the midline crossing arteries in the soft tissues were visible, which represent the facial arcades.

\section{Discussion}

Previous perfusion studies (Baccarani et al., 2006; Banks et al., 2009) have shown the internal maxillary artery branching off the external carotid artery to supply blood to the maxillae. Guo et al. (2008) however, performed the second facial transplant with the ipsilateral maxilla and zygoma and bilateral nasal bones, based on a single facial artery and vein anastamosis. Additionally Pomahac et al. (2010), demonstrated both experimentally (four cadaver heads) and clinically (one case) that bony elements of the midfacial grafts could survive on the facial artery. These successes are supported by other anatomical studies, showing that the maxilla can receive a blood supply from the ascending palatal artery, branching off the facial artery (Dodson et al., 1997; Siebert et al., 1997). The maxillary bone receives its blood supply more from the periosteal vessels (facial artery) than the endosteal vessels (internal maxillary artery).

Former studies on angiosomes of the head have described rich midline anastomoses in the lips and poor anastamoses in the hard palate (Houseman et al., 2000). The palatal gingiva is supplied by the descending palatine artery, a branch of the internal maxillary

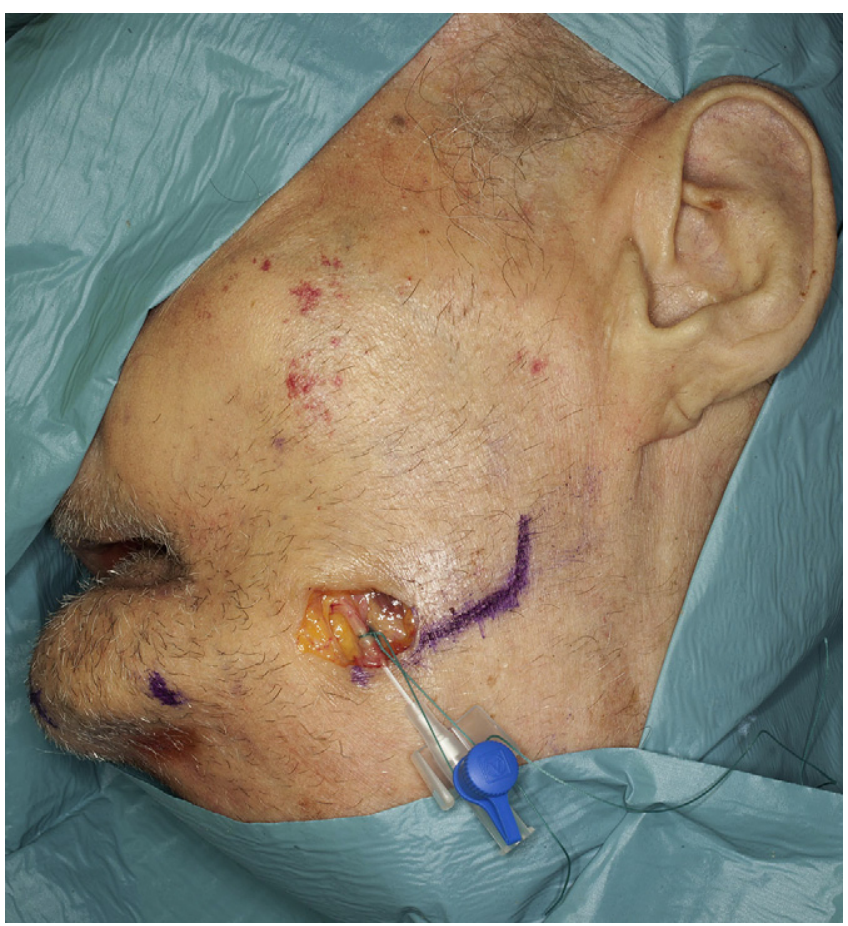

Fig. 1. Cannulated left facial artery at the level of the mandibular border
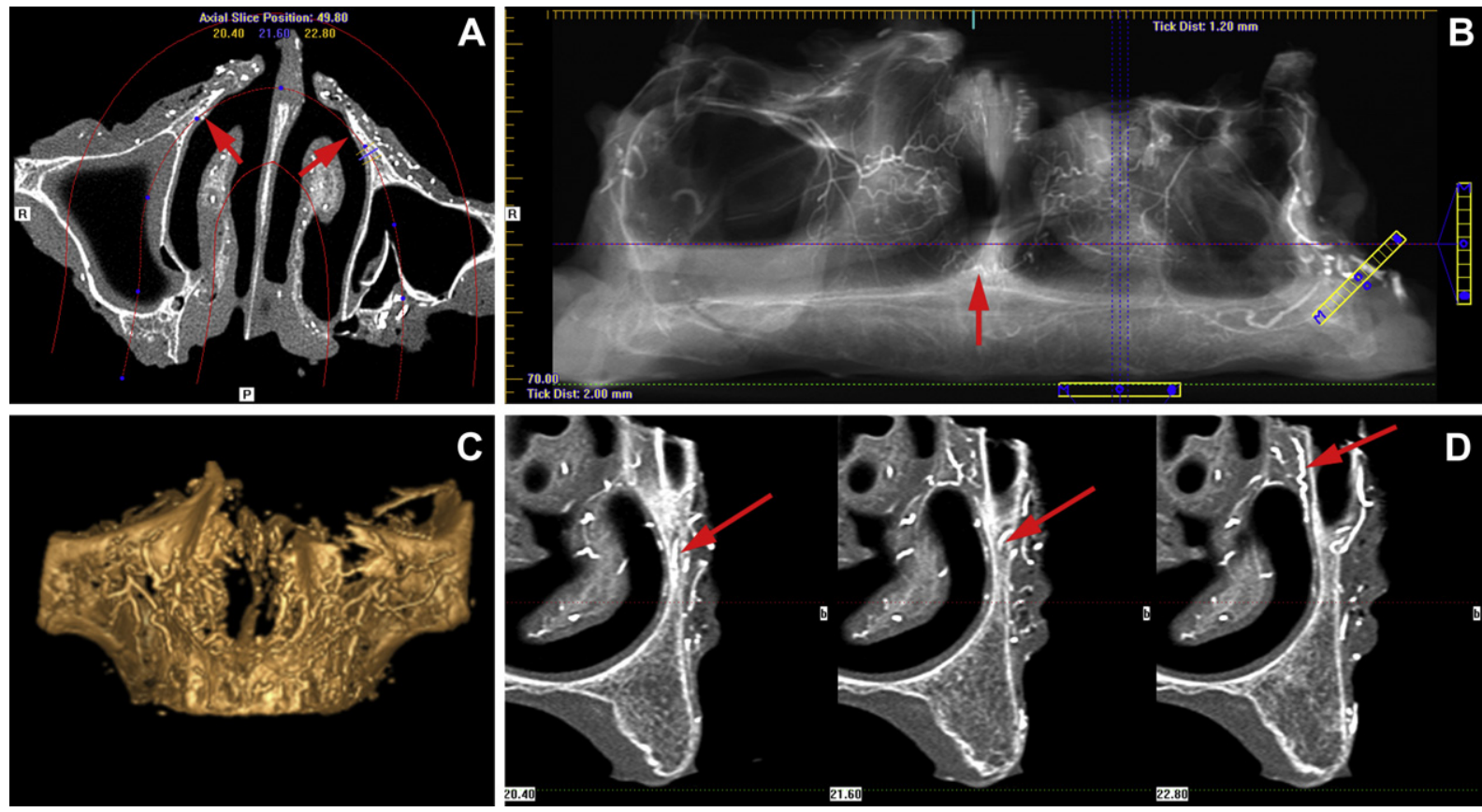

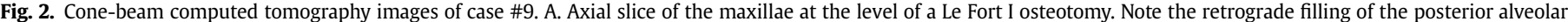

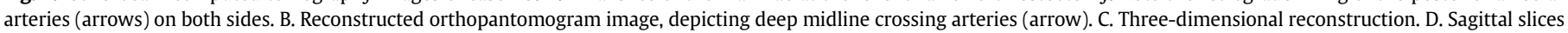
of the ipsilateral maxilla. The contrast agent is visible within the bone (arrows). 

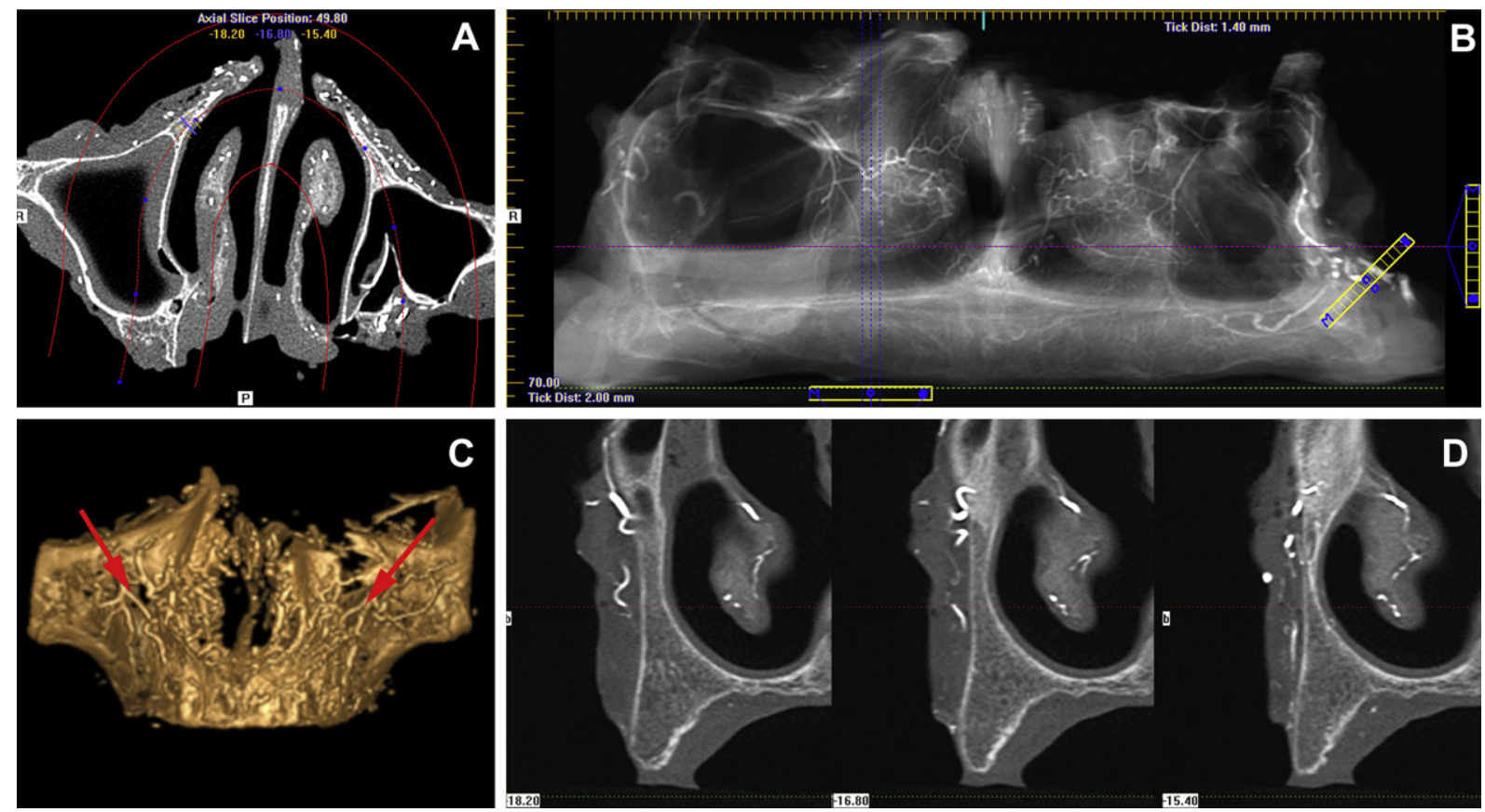

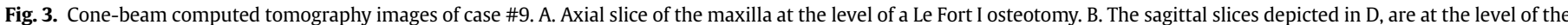

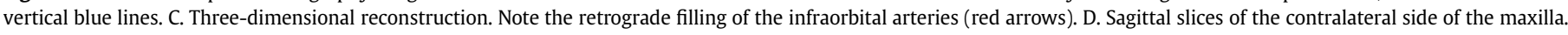
Contrast agent is visible within the bone (red arrows).
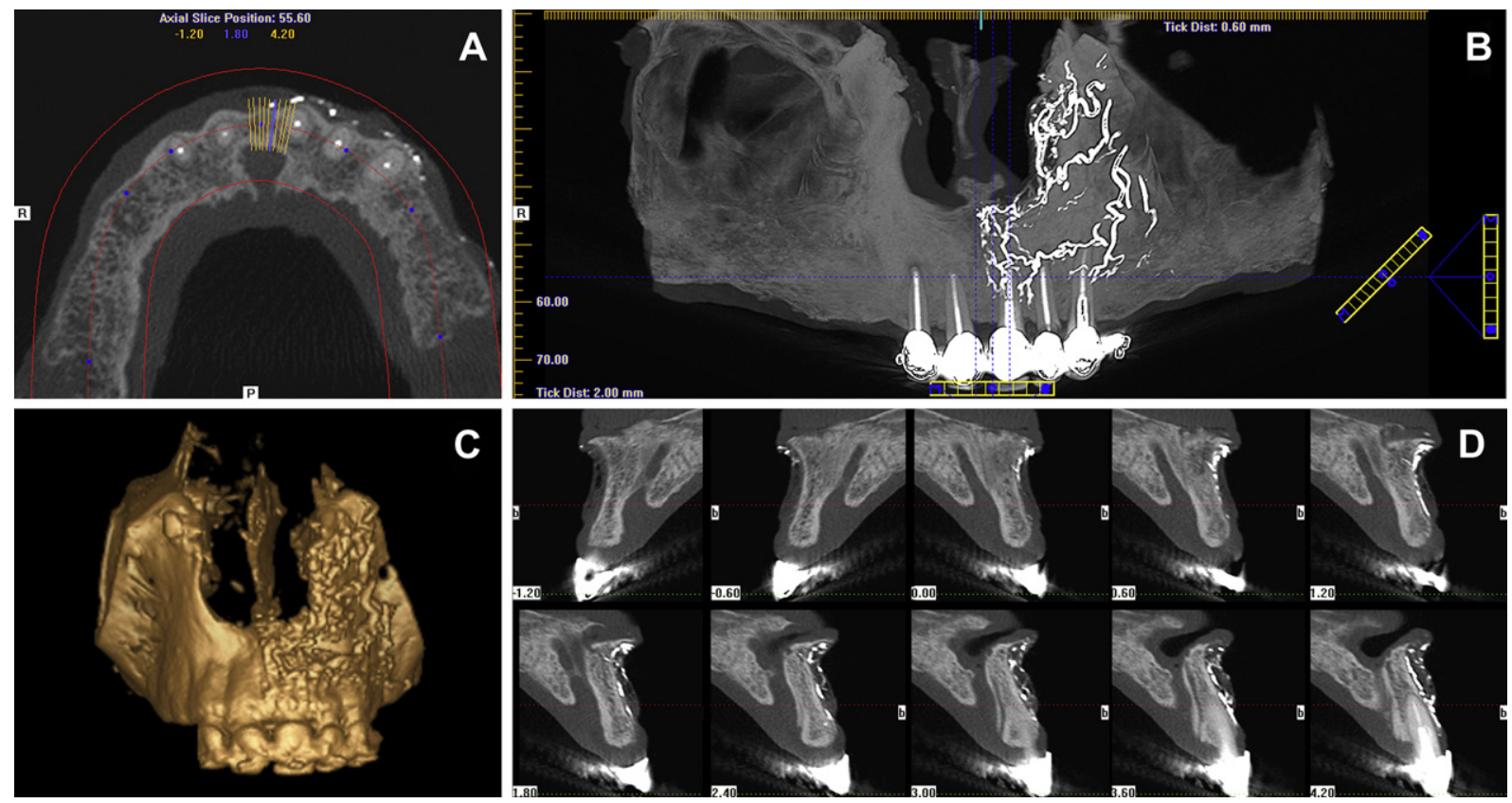

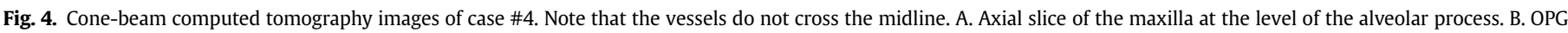
reconstruction. C. Three-dimensional reconstruction. D. Sagittal reslices as marked in A.

artery, with little crossover by small vessels (Houseman et al., 2000; Banks et al., 2009). In the soft palate, cross-over anastomosis is abundant, supplied by the ascending palatal artery (Houseman et al., 2000). Banks et al. (2009) also demonstrated perfusion in the "lower" maxilla after cannulation of the facial artery, but observed a sharp demarcation of territories supplied by the left and right external carotid arteries.

Clinically, composite flaps of the ipsilateral maxillary and bilateral nasal bones have been raised on one facial artery for access to the skull base (Curioni et al., 1990) and for use as an allotransplant (Guo et al., 2008). These examples demonstrate the importance of having connecting arteries join the deep branches of the facial artery and distal internal maxillary artery branches (i.e., infraorbital artery, sphenopalatine, and nasopalatine arteries, Pomahac et al., 2010), providing a retrograde blood supply to the maxilla; they also show the importance of midline crossing vessels in the integument (Houseman et al., 2000). Siemionow et al. (2009) transplanted a complete midface via 

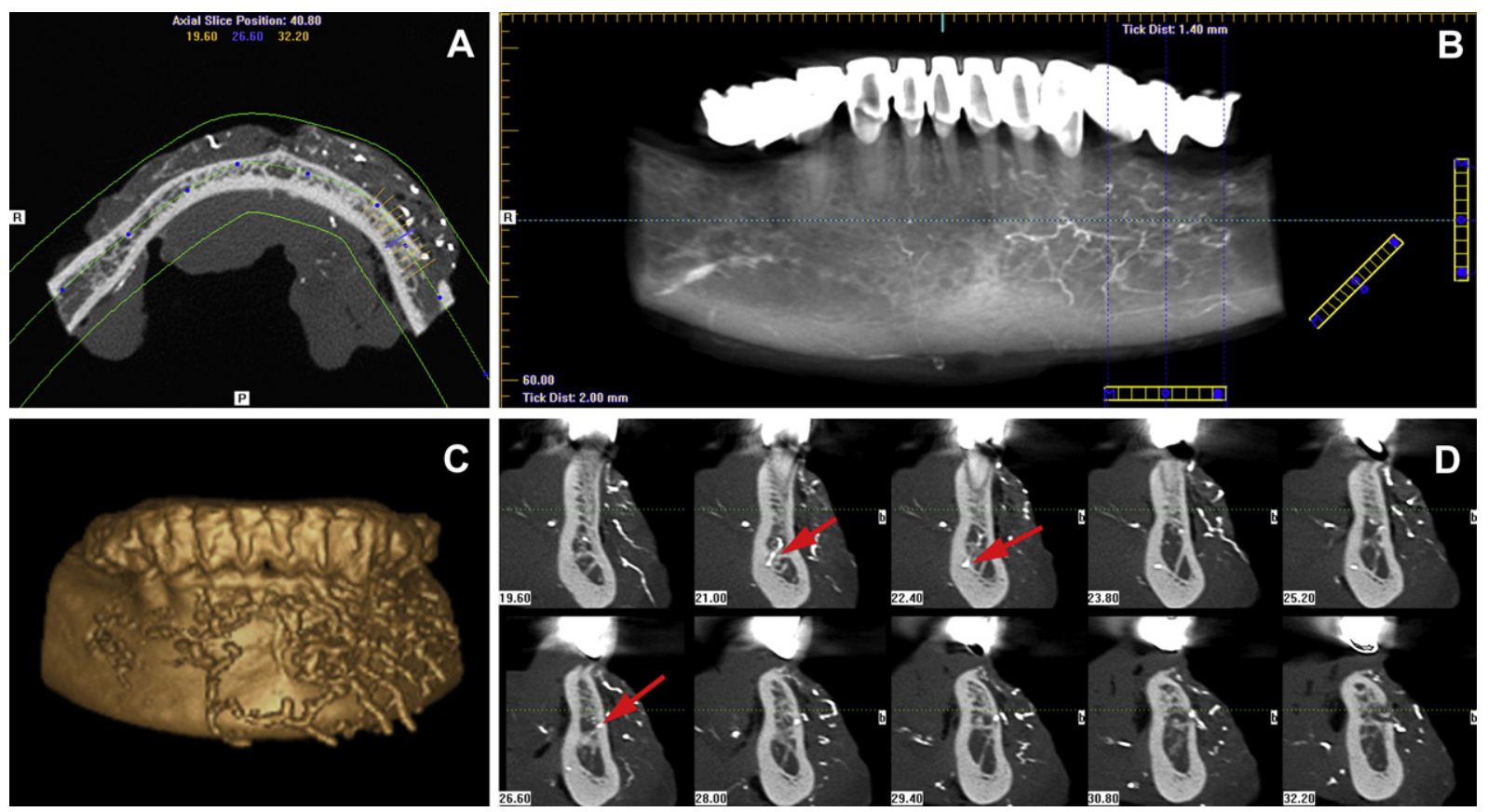

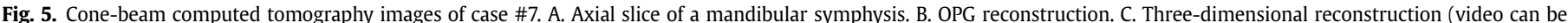
played in the digital version). D. Sagittal slices of the ipsilateral side of the mandible. Contrast agent is visible within the bone (arrows).
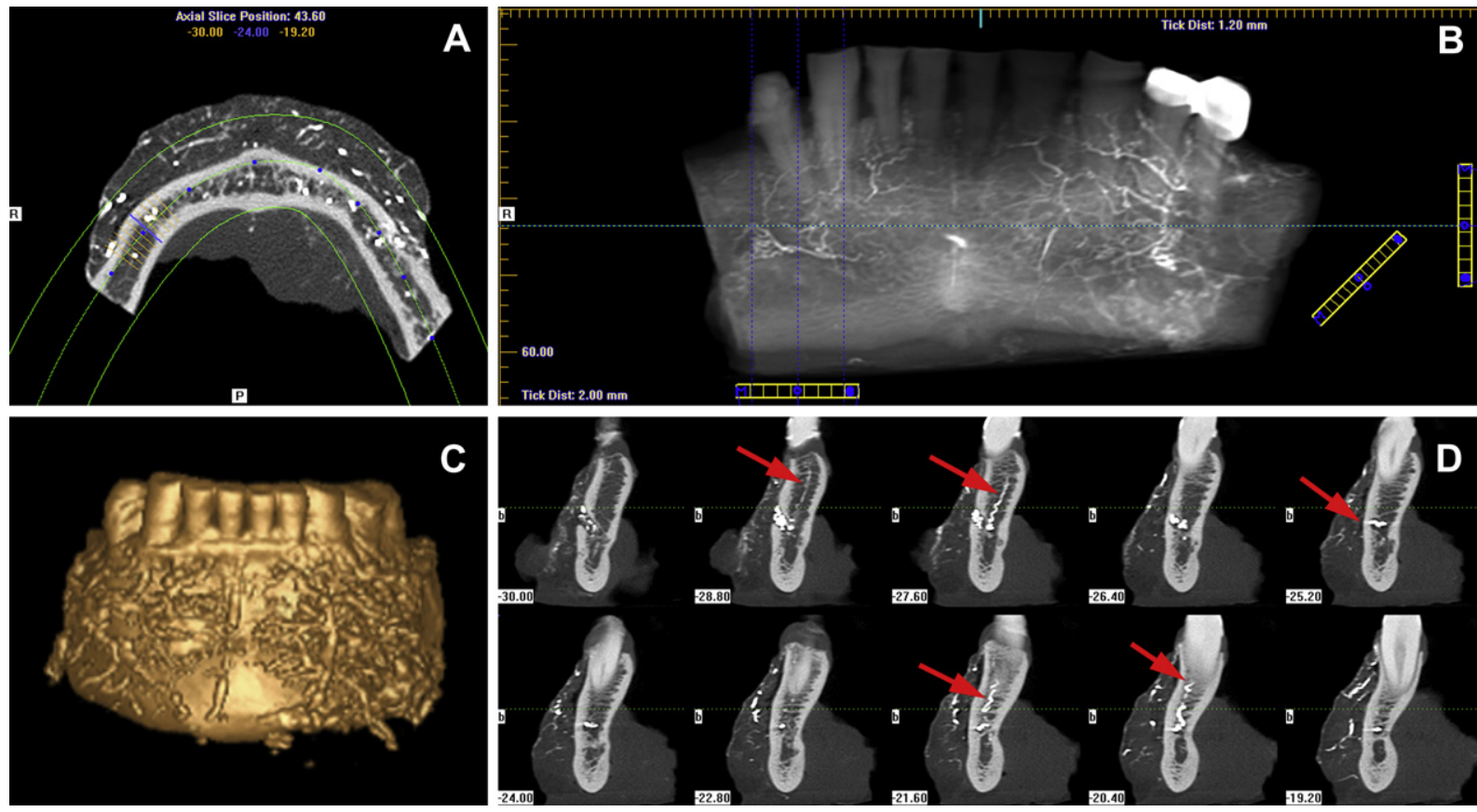

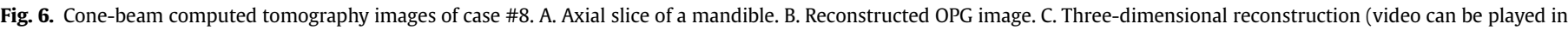
the digital version). D. Sagittal slices of the contralateral side of the mandible. Contrast agent is visible within the bone (arrows).

bilateral, facial artery anastamosis and noted entire graft viability after the first left-sided facial artery anastomosis was accomplished with the allograft skin and the internal anterior mucosa of the alveolus, hard palate, and intranasal mucosa all suddenly pinking up."

In our study, when the contralateral blood supply to the maxilla was observed in $50 \%$ of cases, it meant that midfacial cross-over occurred in those labial "choke" arteries. Harvesting the vessels, muscle, bone, and dentiton on an easily accessible pedicle may allow allotransplantation without highly antigenetic skin. However, the labial arteries (and the bony segment) may be jeopardized because of their close proximity to the skin.

Mandibular bone in both mini-pigs and man is supplied more endosteally in the upper ramus and more periosteally in the symphyseal area (Saka et al., 2002). In the symphyseal area, anastamoses are found between the mental artery (of external carotid 
artery origin) and the submental and sublingual arteries (of facial arteries origin) (Bradley, 1972, 1981). Once outside of the submandibular gland and before curving around the mandibular border, the facial artery can only connect the symphyseal bone via deep branches of the inferior labial artery. In dogs, the mandibular symphysis is endosteally supplied by the inferior alveolar artery, but periosteo-medullary anastomoses from the submental artery, a branch of the facial artery, dominate in cases of central block (Hellem and Östrup, 1981).

These observations corroborate our perfusion study. The ipsilateral symphysis (Lengelé type I/B flap) will survive on the ipsilateral facial artery as a periosteally vascularized bone flap.

It is possible that contralateral perfusion would exist in all cases; however, this possibility cannot be demonstrated because of the post-mortem conditions of the tissue. Bilateral anastomosis is certainly recommended in all cases because technical failure from vessel thrombosis occurs in $2 \%$ of all flaps used for head and neck reconstruction (Cugno et al., 2007).

\section{Conclusion}

The maxilla and anterior mandible lie in the vascular bed of the ipsilateal facial artery and in 50\% also of the contralateral facial artery. Internal maxillary artery anastomosis is not per se required for a vascularized maxillary bone flap, nor submental artery presence for a mandibular symphyseal bone flap.

\section{Funding}

No grants or company affiliations

\section{References}

Baccarani A, Follmar KE, Baumeister SP, Marcus JR, Erdmann D, Levin LS: Technical and anatomical considerations of face harvest in face transplantation. Ann Plast Surg 57: 483-488, 2006

Banks ND, Hui-Chou HG, Tripathi S, Collins BJ, Stanwix MG, Nam AJ, et al: An anatomical study of external carotid artery vascular territories in face and midface flaps for transplantation. Plast Reconstr Surg 123: 1677-1687, 2009

Bradley JC: Age changes in the vascular supply of the mandible. Br Dent J 132: 142-144, 1972

Bradley JC: The clinical significance of age changes in vascular supply to the mandible. Int J Oral Surg 10: 71-76, 1981

Cugno S, Sprague S, Duku E, Thoma A: Composite tissue allotransplantation of the face: decision analysis model. Can J Plast Surg 15: 146-152, 2007

Curioni C, Clauser L, Squaquara R, Barasti P, Curri D: Cranio-facial resections. Acta Otorhinolaryngol Ital 10: 27, 1990

Dodson TB, Bays RA, Neuenschwander MC: Maxillary perfusion during Le Fort I osteotomy after ligation of the descending palatine artery. J Oral Maxillofac Surg 55: 51-55, 1997

Guo S, Han Y, Zhang X, Lu B, Yi C, Zhang H, et al: Human facial allotransplantation: a 2-year follow-up study. Lancet 372: 631-638, 2008

Hellem S, Östrup L: Normal and retrograde blood supply to the body of the mandible in the dog. II. The role played by periosteo-medullary and symphyseal anastomoses. Int J Oral Surg 10: 31-42, 1981

Houseman ND, Taylor GI, Pan W-R: The angiosomes of the head and neck: anatomic study and clinical applications. Plast Reconstr Surg 105: 2287-2313, 2000

Lengelé BG: Current concepts and future challenges in facial transplantation. Clin Plast Surg 36: 507-521, 2009

Pomahac B, Aflaki P: Composite tissue transplantation: a new era in transplantation surgery. Eplasty 10: 480-482, 2010

Pomahac B, Lengelé B, Ridgway EB, Matros E, Andrews BT, Cooper JS, et al: Vascular considerations in composite midfacial allotransplantation. Plast Reconstr Surg 125: 517-522, 2010

Saka B, Wree A, Anders L, Gundlach KKH: Experimental and comparative study of the blood supply to the mandibular cortex in Göttingen minipigs and in man. J Craniomaxillofac Surg 30: 219-225, 2002

Siebert JW, Angrigiani C, McCarthy JG, Longaker MT: Blood supply of the Le Fort I maxillary segment: an anatomic study. Plast Reconstr Surg 100: 843-851, 1997

Siemionow M, Papay F, Alam D, Djohan R, Bernard S, Gordon CR, et al: Near-total human face transplantation for a severely disfigured patient in the USA. Lancet 374: 203-209, 2009 
IV 


\title{
High-quality image acquisition by double exposure overlap in cone beam computed tomography
}

\author{
Mark Plachtovics, DMD, ${ }^{\mathrm{a}}$ Peter Bujtar, MD, DMD, MSc, ${ }^{\mathrm{b}}$ Katalin Nagy, DDS, PhD, ${ }^{\mathrm{d}}$ and \\ Maurice Mommaerts, $\mathrm{MD}, \mathrm{DMD}, \mathrm{PhD}^{\mathrm{c}}$ \\ University of Szeged, Szeged, Hungary; University of Oulu, Oulu, Finland; European Face Centre, Vrije Universiteit Brussel, Brussels, Belgium
}

Objective. With a double exposure overlapping cone beam computed tomography (CBCT) scan technique, using CBCT acquisition radiation dose, the objective was to obtain apparent density similar to that of multidetector computed tomography (MDCT).

Study Design. Factory quality-assurance phantom and water phantom were used for the evaluation of apparent density fidelity of iCAT scans in different modes. Each scan's apparent density was analyzed for identical regions using Imagej, version 1.42q. Results. The iCAT Classic extended height acquisition with 4-cm central overlap and reconstruction of 2 groups of 300 projections per rotation for the water and quality-assurance СВCT phantoms resulted in improved apparent density fidelity. This apparent density accuracy was superior to that of iCAT scan at high resolution (600 projections during 1 rotation). Conclusions. Using double exposure overlapping CBCT scans allows the analysis quality to be comparable with that of MDCT. (Oral Surg Oral Med Oral Pathol Oral Radiol 2014;117:760-767)

Cone beam computed tomography (CBCT) was originally developed in 1982 for angiography, ${ }^{1,2}$ and more than a decade later it was applied to dentomaxillofacial diagnostics. The main advantages of CBCT are relatively high-resolution acquisition and, compared with conventional CT, lower radiation doses with smaller and less expensive equipment. ${ }^{1-11}$

Multidetector CT (MDCT) is superior for the contrast of soft and hard tissues. Hounsfield units (HU) offer reliability and accurate comparisons, and the field of interest can be easily extended. CBCT allows an estimation of soft tissue quantities, ${ }^{12}$ whereas apparent density $^{3}$ (AD) measurements (density values in the CBCT images) are inaccurate, even when high-contrast materials are used.

From a technical point of view, the limitation of image quality is dependent on the increased $\mathrm{x}$-ray scatter. This not only increases patient dose but also is a principal contributor to reduced contrast resolution and increased noise in CBCT images, ${ }^{2,5,13}$ therefore influencing the density values. ${ }^{2,7-11,14-18}$

In oral implantology, it is very important to obtain initial information about the quality (density) of the bone, as the type and architecture of bone is known to influence its load-bearing capacity. It has been found previously that poorer-quality bone is associated with

\footnotetext{
${ }^{a}$ Research Associate, University of Szeged, Faculty of Dentistry.

${ }^{b}$ Research Associate, Oral and Maxillo-Facial Surgery Department, University of Oulu.

${ }^{\mathrm{c}}$ Professor, Department of Cranio-Maxillo-Facial Surgery, European Face Centre, Vrije Universiteit Brussel.

${ }^{\mathrm{d}}$ Professor, University of Szeged, Faculty of Dentistry.

Received for publication Nov 26, 2013; returned for revision Feb 11, 2014; accepted for publication Feb 19, 2014.

(C) 2014 Elsevier Inc. All rights reserved.

$2212-4403 / \$$ - see front matter

http://dx.doi.org/10.1016/j.oooo.2014.02.024
}

higher failure rates of different dental treatments. ${ }^{19,20}$ Khoury et al. ${ }^{21}$ reported that the success of oral rehabilitation with the use of oral implantation depends first on the bone quality of the jaw. The initial stability of the endosseous implant is essential for such success, which nevertheless depends on both the quality and quantity of the surrounding bone. On the other hand, the main disadvantage of dental CBCT imaging, in guided implant surgery, is the unreliability of the magnitude range of density values in the soft tissues, which can only be corrected with appropriately shaped prosthetic surgical guides. At the same time, optimizing image precision is only possible using special reconstructive algorithms to achieve the same efficiency as MDCT. ${ }^{21}$ The problem, however, has not been fully clarified. Several authors have written about the possibility of the application of CBCT image density value measurements, ${ }^{3-6,16,19,22}$ whereas others believe that the use of intensity values from CBCT images is unreliable. . $^{7,9,10,14,15,18,23,24}$

Reconstructing the density function of a 3-dimensional (3D) object, via $\mathrm{x}$-ray projection data, can be formulated mathematically as recovering the density function from its line integrals. The reduction of the dimension of the problem from $3 \mathrm{D}$ to $2 \mathrm{D}$ can be done by considering $3 \mathrm{D}$ objects as a stack of their cross-section.

\section{Statement of Clinical Relevance}

In this work, with the application of a new technique, the accuracy of multidetector computed tomography was achieved with low-cost cone beam computed tomography. This achievement will help widespread clinical and dental implant utilization. 
Table I. Parameters for the 4 different applied scans and reconstruction modes of the iCAT Classic 14-bit grayscale resolution cone beam computed tomography dental imaging system

\begin{tabular}{lcccc}
\hline \multicolumn{1}{c}{ Abbreviation of acquisition mode } & RD300 04 & RD600 04 & RD600 02 & EFOV 04 \\
\hline Number of raw data (RD) 2D projections & 300 & 600 & 600 & $300+300$ \\
Degrees of rotation & $360^{\circ}$ & $360^{\circ}$ & $360^{\circ}$ & $360^{\circ}+360^{\circ}$ \\
Slice thickness of the reconstruction & $0.4 \mathrm{~mm}$ & $0.4 \mathrm{~mm}$ & $0.2 \mathrm{~mm}$ & $0.4 \mathrm{~mm}$ \\
Tube current (mA·s) & 18.45 & 36.12 & 36.12 & 12.45 \\
Tube voltage (kilovolt peak) & 120 & 120 & 120 & 120 \\
Diameter of the FOV (mm) & 154 & 60 & 60 & 154 \\
Height of the FOV (mm) & 60 & 40 & 40 & 220 \\
Scan times (seconds) & 20 & 7.2 & 7.2 & $20+20$ \\
Exposure time (seconds) & 3.6 & 3.24 & 3.24 & $3.6+3.6$ \\
Measured dose at detector (mGy) & 1.65 & & $1.65+1.65$ \\
\hline
\end{tabular}

Equipment characteristics: exposure type, pulsed; focal spot size, $0.5 \mathrm{~mm}$; minimum filtration, $10 \mathrm{~mm}$ or larger (expressed in millimeters of aluminum equivalent) as mentioned in the iCAT operator's manual in Chapter 8; voltage wave shape, constant potential.

$M D C T$, in our study's tables and figures, is the abbreviation for the General Electric multidetector computed tomography scan. The EFOV 04 is the 4-cm height overlapping region of the iCAT Classic 22-cm height for Optional Extended Height acquisition with 0.4-mm slice thickness. This scan protocol consisted of 2 separate 13-cm-high 300 2D raw data (RD) projections. For the reconstruction of the 4-cm-high overlapping region, the 2 groups of 300 projections $(300+300)$ were used simultaneously. The RD300 04 operation mode represents the iCAT CBCT with 0.4-mm slice thickness, and the number of frames is 300 . The RD600 04 operation mode represents the iCAT CBCT with 0.4-mm slice thickness, and the number of frames is 600. The RD600 02 mode used the iCAT CBCT with 0.2-mm slice thickness, and the number of frames is 600 .

This reduction allows use of the Radon inversion formulas, or their equivalents, which are available for reconstructing single cross-sections of the objects. ${ }^{25}$

From a technical point of view, using the Feldkamp algorithm or its modifications, all CBCT equipment reconstructs volume from a high number of 2-dimensional (2D) x-ray projections acquired from a circular orbit around the target object, which compose the socalled raw data (RD). The Feldkamp algorithm is an approximate cone beam reconstruction algorithm, and it is probably the most widely used cone beam algorithm. It is well known that reconstructions from 1 circular orbit are insufficient for an accurate reconstruction of volume. It has been mathematically proven that reconstructing from such inadequate data violates the fundamental Tuy condition, which requires that every plane intersecting the object under study must intersect the focal trajectory. ${ }^{17,25,26}$ A similar suggestion has been made by Molteni in a recent publication ${ }^{14}$ regarding the use of software more accurate than that which uses the Feldkamp algorithm.

Using the concept of sequential cone beam computed tomography (SCBCT) developed by Köhler, Proksa, and Grass in $2000,{ }^{27}$ which appears to be a generalization of the Tuy condition, we made a practical application for our CBCT scans. In this process, we used 2 circular orbits at different heights with reduced basic projection numbers within the same field of view (FOV). As a result of this, apparent density fidelity could be increased according to a single-cycle highernumber basic projection acquisition.

The clinical relevance is that the radiation dosage that the patient is exposed to during an examination is a definite point in question, which is discussed by previous authors. ${ }^{28}$ The double exposure does not mean double dosage. In the double exposure dental CBCT, instead of a 600 basic projection data set (600 RD), two 300 basic projection data sets are used, and therefore no extra exposure occurs, as illustrated by Table I.

\section{MATERIALS AND METHODS}

To satisfy the SCBCT requirements, the CBCT acquisition procedure consisted of 2 single-cycle, low-number, basic projection scans (300 RD + $300 \mathrm{RD})$ with parallel, central beams at 2 different fixed heights along the vertical dimension within the same FOV (Figure 1). The iCAT Classic (Imaging Sciences International, Hatfield, PA, USA) equipment was used for $20+20$ second duration exposure (300 RD + $300 \mathrm{RD})$, with $22-\mathrm{cm}$ height optional expanded FOV and 0.4-mmthick slice scan with a 4-cm overlap. The reconstruction of this 4-cm height overlap region of the FOV (EFOV 04) does not stitch the reconstructed axial slice data of the 2 FOVs; the 2D projection RD acquisitions are used simultaneously. The iCAT Cone Beam Dental Imaging System is powered by the XoranCAT technology acquisition program, version 3.1.62 (Xoran Technologies Inc, Ann Arbor, MI, USA). The XoranCAT version 3.1.62 uses the raw $2 \mathrm{D}$ reconstruction data to calculate and optimize 3D array concatenation. The alignment of the overlapping 2D arrays is determined by calculating fractional differences in angular registration; each axial position will have its own fractional displacement coefficient.

Table I shows the technical parameters associated with 4 different acquisition modes. We compared the $\mathrm{AD}$ accuracies measured in $\mathrm{HU}^{3,9,10,13,15,19,22}$ of the 4 different acquisition modes of the iCAT Classic single 


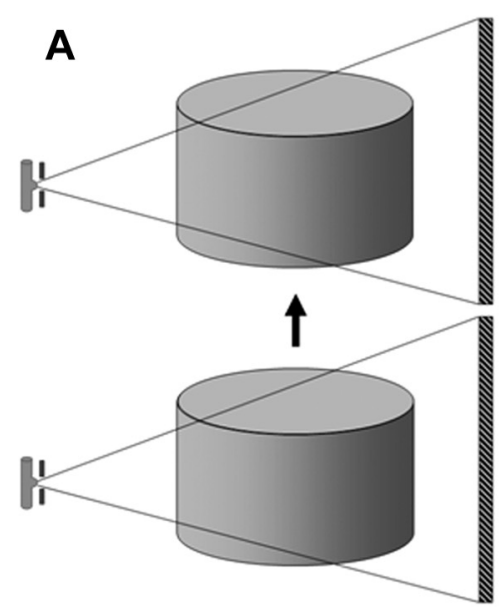

B

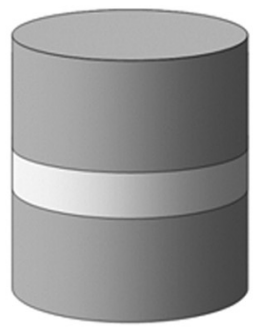

C

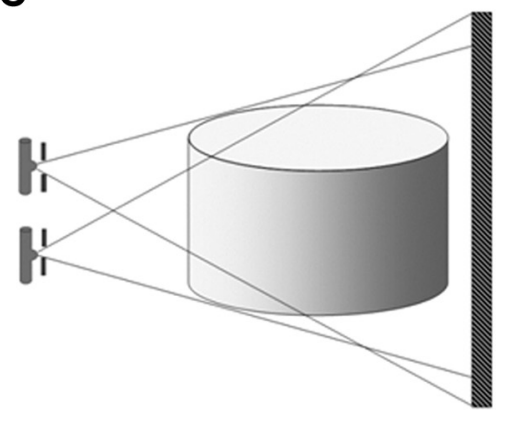

Fig. 1. The schematic representation of basic acquisition procedures. A, iCAT Classic Extended Height acquisition $(20+20-$ second exposition, 22-cm height optional extended field of view [EFOV]), which was reconstructed during fusion of 2 separate 300 projections. B, The overlapping 4-cm-high region (EFOV 04) of the 22-cm height extended height acquisition mode (white color marked, 300 raw data [RD] + 300 RD) of the study configuration. The reconstruction of the EFOV 04 was made using both scans' RDs simultaneously. C, This method is proposed in the simplest way to achieve a double exposure overlapping cone beam computed tomography with 2 rotations using the same detector with a differently positioned and collimated x-ray source within the top and bottom planes of the field of view. Using 2 x-ray sources simultaneously would increase the price of this new device.

$\mathrm{X}$-ray source CBCT dental imaging system (see Table I) using an MDCT (General Electric [GE] Medical Systems LightSpeed VFX Ultra, Tokyo, Japan, 120 kilovolt peak, $144.91 \mathrm{~mA} \cdot \mathrm{s})$. The influence of the number of projections and reconstructed slice thickness were examined to determine the effects on both AD accuracy and standard deviation (SD). This in vitro study was performed with both a quality-assurance phantom and a water phantom. The standard Imaging Sciences International (ISI) CBCT quality-assurance phantom is a cylindrical CBCT phantom with a $150-\mathrm{mm}$ diameter (Figure 2), which is made of Teflon $\left(2.16 \mathrm{~g} / \mathrm{cm}^{3}\right)$, lowdensity polyethylene (LDPE) $\left(0.92 \mathrm{~g} / \mathrm{cm}^{3}\right)$, acryl $(1.18$ $\left.\mathrm{g} / \mathrm{cm}^{3}\right)$, and air $\left(1.2928 \mathrm{~kg} / \mathrm{m}^{3}\right)$ embedded in a Plexiglas cylinder. This phantom was always placed in the same position on a foam layer in the center of the FOV to avoid both an exo-mass effect and comb-like artifacts. The phantom was positioned such that the section of the central beam did not cross the line pair centers. The 4 relatively smaller cylinders within the ISI phantom with well-defined material density (air, LDPE, acryl, and Teflon) were measured by sampling 3 circle-type regions of interest, each $3 \mathrm{~mm}^{2}$, for each cylinder in the middle slices. According to the operator's manual, making the measurement in the middle slice is an accepted procedure to obtain apparent density fidelity. Spatially, the 3 sampling areas were distributed as follows: 1 was in the center of the cylinder, and 2 were along the line connecting the center of the FOV to the middle of the cylinder; both were equidistant from the center of the cylinder, one toward the outer and the other toward the inner part of the FOV. The measured

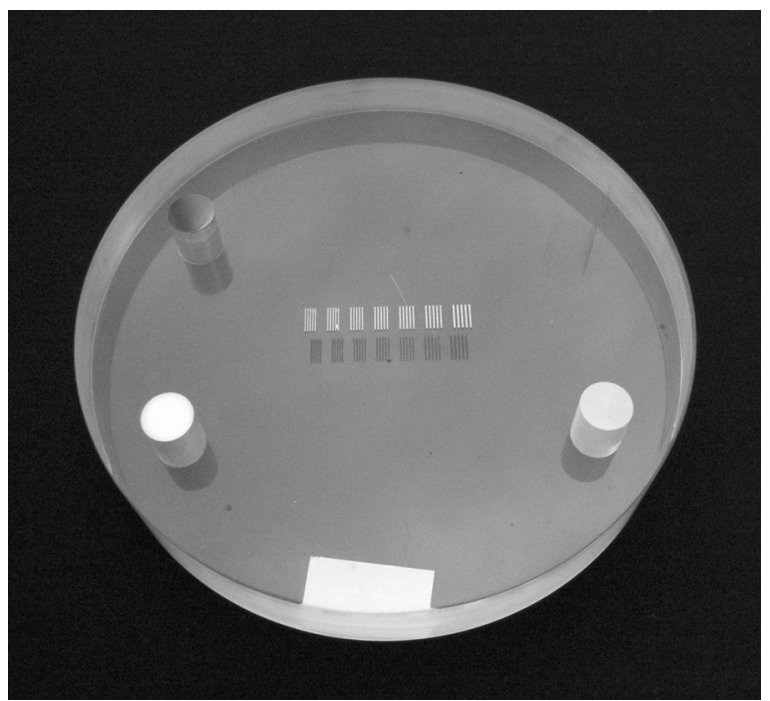

Fig. 2. The cylindrical (150-mm diameter) Imaging Sciences International quality-assurance cone beam computed tomography phantom.

distances from the center of the FOV, the $\mathrm{AD}$, and the $\mathrm{SD}$ of the corresponding 3 samples were averaged.

On the axial planes, the water phantom (an 18-cm diameter plastic dish filled with water) was hanging symmetrically over the FOV to eliminate the asymmetry of the exo-mass effect. By using such local tomography, we were able to analyze the image of the entire FOV. The water phantom was more suitably measured with a larger 200- $\mathrm{mm}^{2}$ circle-type region of interest at 5 equidistant locations along a line from the 
Table II. Mean apparent density (AD) and standard deviation (SD) values of the standard Imaging Sciences International Inc quality-assurance phantoms

\begin{tabular}{|c|c|c|c|c|c|c|c|c|}
\hline \multirow{2}{*}{$\frac{\text { Position }}{\text { RD600 } 02}$} & \multicolumn{2}{|c|}{1.00} & \multicolumn{2}{|c|}{2.00} & \multicolumn{2}{|c|}{3.00} & \multicolumn{2}{|c|}{4.00} \\
\hline & $A D$ & $S D$ & $A D$ & $S D$ & $A D$ & $S D$ & $A D$ & $S D$ \\
\hline Teflon & 895.27 & 105.26 & 919.20 & 91.82 & 911.42 & 83.90 & 867.95 & 103.25 \\
\hline LDPE & -315.63 & 88.20 & -335.60 & 98.03 & -333.45 & 83.43 & -334.10 & 99.54 \\
\hline Acryl & -69.84 & 92.15 & -75.32 & 103.70 & -82.72 & 85.62 & -79.81 & 93.42 \\
\hline Air & -1000.00 & $0.00^{*}$ & -1000.00 & $0.00^{*}$ & -1000.00 & $0.00^{*}$ & -1000.00 & 0.00 * \\
\hline
\end{tabular}

LDPE, low-density polyethylene.

Phantoms are positioned in 4 different concentric rotational positions $\left(90^{\circ}\right)$ in the analysis of the iCAT Classic cone beam computed tomography imaging system (RD600 02). The rotation of the phantom does not cause significant changes in AD fidelity.

*SD values cannot be determined, owing to saturation.

Table III. Measured density values for quality-assurance phantom

\begin{tabular}{|c|c|c|c|c|c|c|c|c|c|c|}
\hline & \multicolumn{2}{|c|}{ RD300 04} & \multicolumn{2}{|c|}{$R D 60004$} & \multicolumn{2}{|c|}{ RD600 02} & \multicolumn{2}{|c|}{ EFOV 04} & \multicolumn{2}{|c|}{$M D C T$} \\
\hline & $A D$ & $S D$ & $A D$ & $S D$ & $A D$ & $S D$ & $A D$ & $S D$ & $A D$ & $S D$ \\
\hline Teflon & 789.68 & 39.09 & 866.00 & 39.99 & 867.95 & 103.25 & 1009.02 & 36.73 & 965.94 & 17.72 \\
\hline LDPE & -378.51 & 49.36 & -372.44 & 45.24 & -334.10 & 99.54 & -119.32 & 28.80 & -104.10 & 18.01 \\
\hline Acryl & -119.68 & 38.80 & -127.34 & 35.22 & -79.81 & 93.42 & 135.94 & 26.73 & 115.16 & 16.61 \\
\hline Air & -997.25 & 7.29 & -1001.66 & 8.92 & -1000.00 & $0.00 *$ & -998.94 & 9.13 & -999.24 & 14.56 \\
\hline
\end{tabular}

$A D$, mean apparent density in Hounsfield units; $S D$, standard deviation values of 5 acquisition methods using the standard Imaging Sciences International Inc quality-assurance phantom; $L D P E$, low-density polyethylene.

$*$ SD values cannot be determined, owing to saturation.

Table IV. Measured density values for the water phantom

\begin{tabular}{|c|c|c|c|c|c|c|c|c|c|c|}
\hline \multirow[b]{2}{*}{ Distance from the center $(\mathrm{mm})$} & \multicolumn{2}{|c|}{ RD300 04} & \multicolumn{2}{|c|}{$R D 60004$} & \multicolumn{2}{|c|}{$R D 60002$} & \multicolumn{2}{|c|}{ EFOV 04} & \multicolumn{2}{|c|}{$M D C T$} \\
\hline & $A D$ & $S D$ & $A D$ & $S D$ & $A D$ & $S D$ & $A D$ & $S D$ & $A D$ & $S D$ \\
\hline 0.00 & -292.14 & 65.95 & -281.86 & 48.29 & -249.50 & 153.84 & -65.14 & 41.91 & -2.45 & 38.24 \\
\hline 16.00 & -298.97 & 64.09 & -290.12 & 46.67 & -258.69 & 141.73 & -57.90 & 43.45 & 2.77 & 39.10 \\
\hline 32.00 & -317.84 & 64.56 & -317.83 & 49.71 & -295.77 & 142.53 & -55.97 & 43.93 & 0.79 & 31.20 \\
\hline 48.00 & -364.69 & 66.64 & -375.89 & 50.39 & -365.51 & 146.69 & -65.15 & 41.07 & 2.62 & 23.39 \\
\hline 64.00 & -456.02 & 66.12 & -504.09 & 67.41 & -489.82 & 147.84 & -75.57 & 42.95 & 3.10 & 21.79 \\
\hline
\end{tabular}

$A D$, mean apparent density in Hounsfield units; $S D$, standard deviation values of 5 acquisition methods using the water phantom.

center of the FOV toward the peripheral region in the same direction.

The ISI and water phantoms were scanned, and data were converted into a Digital Imaging and Communications in Medicine (DICOM) format. These data were exported into ImageJ, version 1.42q (Wayne Rasband, National Institutes of Health, Bethesda, MD, USA) to analyze and determine the $\mathrm{AD}$ and $\mathrm{SD}$ in the axial planes.

The examinations were performed in 4 groups:

1. The ISI quality-assurance CBCT phantom was used in 4 different concentric rotational positions about its main longitudinal axis to determine whether orientation caused an effect. Initially, in the setup verification, 4 positions were examined. Each of the scans was performed based on the iCAT user manual instructions and conditions (RD600 02).

2. The ISI quality-assurance CBCT phantom was used in the same position to examine the $\mathrm{AD}$ accuracy of the 4 different acquisition modes of the iCAT Classic equipment (see Table I) compared with the GE MDCT.

3. The same $18-\mathrm{cm}$ diameter plastic dish filled with water (water phantom) was used in each scan.

4. Linear regression analysis was applied to study the relationship between the predetermined volumetric mass density, the specific gravity $\left(\mathrm{g} / \mathrm{cm}^{3}\right)$ of the samples, and the measured $\mathrm{AD}$ (in $\mathrm{HU}$ ).

\section{RESULTS}

1. The rotation of the ISI phantom did not cause significant changes in AD accuracy (Table II; Teflon, $F=0.0368$; LDPE, $F=0.0069$; and acryl, $F=$ 0.0024). This was the setup verification, which shows no significant variation. Therefore, from this point forward, the ISI quality-assurance phantom was maintained in the same position, and only 1 scan was taken for each CBCT image. 

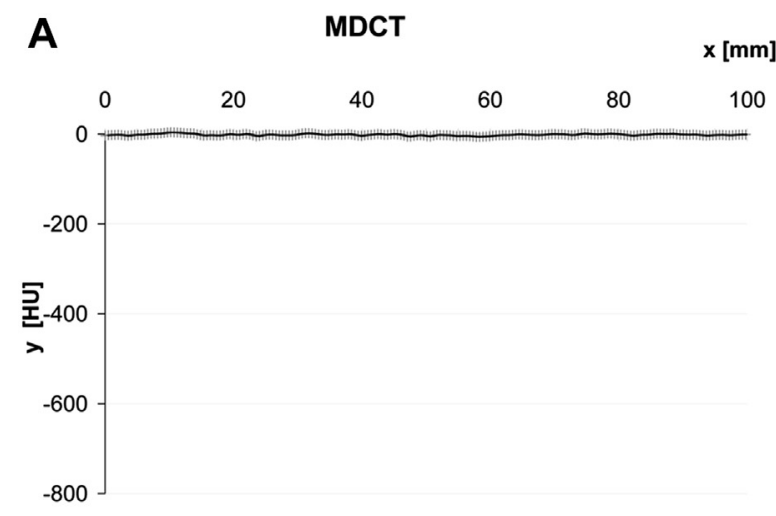

C

RD600 02

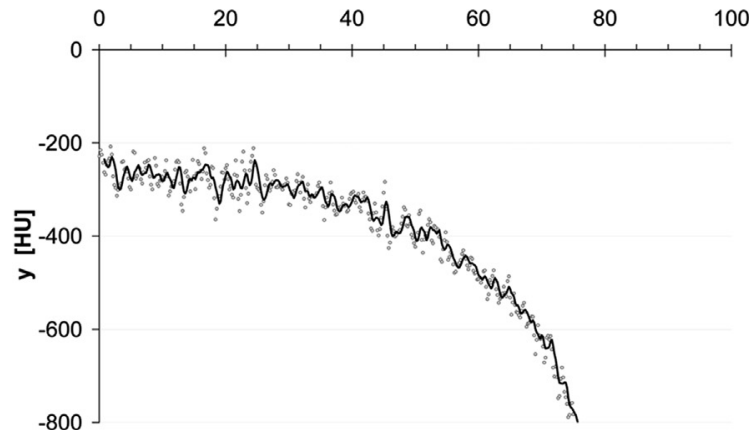

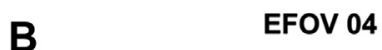

B

EFOV 04

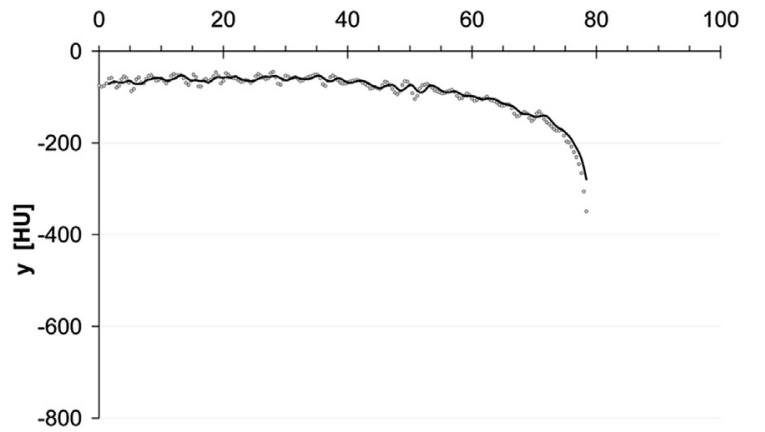

RD600 04

$\mathbf{x}[\mathrm{mm}]$
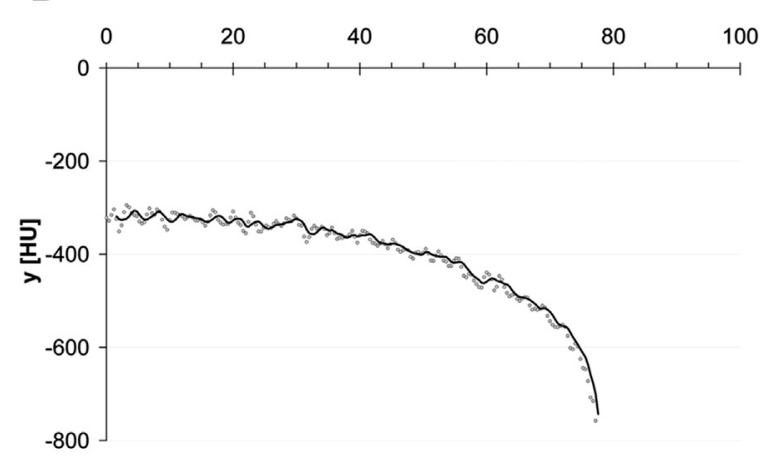

E

RD300 04

$$
x[\mathrm{~mm}]
$$

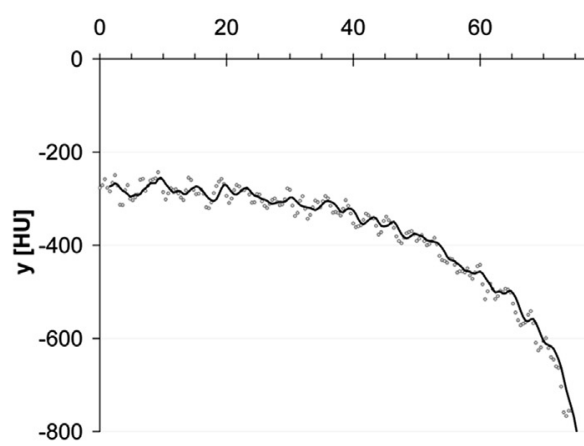

Fig. 3. Water phantom apparent density in the axial plane within the height of the central beam from the center to the periphery. All diagrams were generated with ImageJ, version 1.42q. The horizontal axis is the distance from the isocenter toward the periphery. Note that the center of the water phantom is at zero. A, MDCT. B, EFOV 04. C, RD600 02. D, RD600 04. E, RD300 04. Properties for system and their acquisition protocols chosen for this study are in Table I. (MDCT, multidetector computed tomography; EFOV, extended field of view; $H U$, Hounsfield units.)

2. The GE MDCT produced significantly more accurate $\mathrm{AD}$ values and a lower noise level compared with CBCT; therefore, MDCT scans were used as a reference. ${ }^{5,7,10}$ Disregarding RD600 02 value, only 1 exception was observed: the mean apparent density values of air (listed in the last row of Table III). When comparing the single-cycle $300 \mathrm{RD}$ and 600 $\mathrm{RD}$ acquisitions of the iCAT Classic CBCT imaging system, higher $\mathrm{RD}$ and resolution produced more accurate $\mathrm{AD}$ values, although the $\mathrm{SD}$ increased (see Table III). Higher numbers of the 2D projections with the same voxel size reduced image noise. The EFOV 04 result produced clinically more relevant and accurate $\mathrm{AD}$ using lower $\mathrm{SD}$ values by the ISI phantom compared with 2 single cycles of $300 \mathrm{RD}$ and 600 RD CBCT acquisitions. This was especially true in the case of the acryl sample. The EFOV 04 is the only $\mathrm{CBCT}$ acquisition mode that has a positive 
AD value by acryl like MDCT. This is an interesting observation, not only for the Teflon-like density values of hard tissues (such as compact bone or water) but also for the dense regions of trabecular bone (corresponding to the acryl sample) and for soft tissues, such as fat (corresponding to LDPE; Tables III and IV), which are in the density range of the surgical guide materials. These EFOV $04 \mathrm{AD}$ values were nearest to the MDCT results, emphasizing the importance of this region, which is bounded by the 2 cone beam effects (coming from the top and bottom regions of the 2 separate, single FOVs).

3. The EFOV $04(300 \mathrm{RD}+300 \mathrm{RD})$ and the $6-\mathrm{cm}$ high FOV (300 RD and $600 \mathrm{RD}$; iCAT Classic) single-cycle acquisitions of the water phantom were evaluated (i.e., $\mathrm{AD}$ and $\mathrm{SD}$ ). Each $\mathrm{CBCT} \mathrm{AD}$ value deviated in a negative direction compared with MDCT values (see Table IV). The arch of the AD values in the region closest to the outer border of the FOV was deflected to a greater extent in a negative direction (Figure 3). The density SD decreased with an increasing number of basic projections (RD) with the same voxel size by the single-cycle CBCT scans. An increase in voxel size, with identical RD, decreased the density SD. The arch and value of the $\mathrm{AD}$, which was deflected in a negative direction apparent in the CBCT scan, with a lower number of $\mathrm{RD}$, was very prominent (see Figure 3). The arch of $\mathrm{AD}$ in the axial plane and the mean $\mathrm{AD}$ and $\mathrm{SD}$ values of EFOV 04 (see Table IV) were more accurate than in other CBCT scans.

4. The ISI phantom data are presented in Table III and Figure 4. The calculated regression lines for the ISI phantom provided the numerical coefficients (A and B) of the linear calibration equation, as shown in Table V. These coefficients within the 0.0 to 2.16 $\mathrm{g} / \mathrm{cm}^{3}$ range can be used to approximate the volumetric mass density $(\rho)$, which relies on the AD evaluations (in Hounsfield units [HU]) of materials scanned under similar circumstances. The value of B generally shows the mass density of a volume whose $\mathrm{AD}$ is $0 \mathrm{HU}$, but this is not necessarily true for water in the CBCT scan. While A is the steepness of the line, the linear relation between the mass density $(\rho)$ and the $\mathrm{AD}(\mathrm{HU})$ is:

$$
\rho=\mathrm{A} \times \mathrm{HU}+\mathrm{B}
$$

Based on the $\mathrm{AD}$ data, we measured the calibration equation coefficients that were estimated between the known density and the $\mathrm{AD}$ with a linear regression curve-fitting method. The linear regression of the EFOV 04 proved to be the CBCT result most similar to that of MDCT.

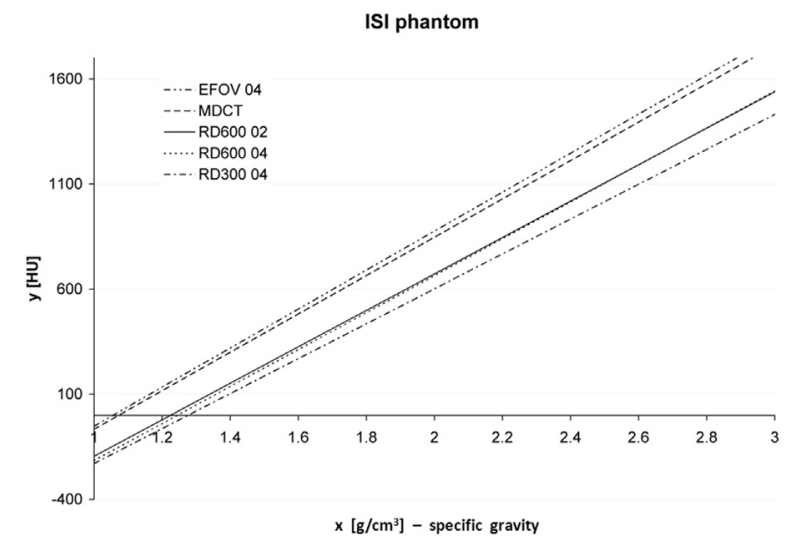

Fig. 4. The graphical results of the linear regression analyses for different scans using the same Imaging Sciences International Inc (ISI) quality-assurance cone beam computed tomography phantom. X-axis: volumetric mass density, specific gravity $\left(\mathrm{g} / \mathrm{cm}^{3}\right) . \quad \mathrm{Y}$-axis: apparent density (HU). (MDCT, multidetector computed tomography; EFOV, extended field of view; $H U$, Hounsfield units.)

Table V. The calibration (equation) coefficients (A and B) and the significance ( $R^{2}$ and SIG) of the correlation

\begin{tabular}{lclcc}
\hline & $A$ & \multicolumn{1}{c}{$B$} & $R^{2}$ & $S I G$ \\
\hline MDCT & 0.001094494 & 1.07327639 & 0.998 & 0.001 \\
EFOV 04 & 0.001076877 & 1.057004494 & 1.000 & 0.000 \\
RD600 02 & 0.001153867 & 1.224908296 & 0.992 & 0.004 \\
RD600 04 & 0.001136747 & 1.245583669 & 0.986 & 0.007 \\
RD300 04 & 0.001203064 & 1.277268949 & 0.991 & 0.005 \\
\hline
\end{tabular}

Linear regression was used to provide the relationship between the volumetric mass density (specific gravity, $\rho$ ) and apparent density (in Hounsfield units) within the 0.0 and $2.16 \mathrm{~g} / \mathrm{cm}^{3}$ range. $\rho=\mathrm{A} \times$ $\mathrm{HU}+\mathrm{B}$.

\section{DISCUSSION}

Our experiments were performed to use the concept of SCBCT, proposed by Köhler, Proksa, and Grass, ${ }^{27}$ to obtain CBCT data of more realistic AD and lower SD values, compared with other scan modes using iCAT Classic dental CBCT. This application would provide clinicians with new possibilities for preoperative evaluation of bone density. ${ }^{19-21}$

A limitation of this in vitro study was that our test objects presented uniform densities, whereas the density of trabecular bone is not uniform. We believe that in the dental CBCT reconstruction process (EFOV 04), we can obtain better AD fidelity compared with additional postprocessing modification methods. The $\mathrm{AD}$ fidelity of this method (EFOV 04) resulted in values nearest to those obtained with MDCT compared with other single-rotation iCAT Classic dental CBCT imaging methods. This is particularly true for those that are operating with the same number of basic projections (RD). Using the $\mathrm{AD}$ values of our study, it was possible 
to determine density conversion coefficients/factors for CBCT machines, as well. $3,5,16,19,22$

A potentially promising step would be to program this method into new CBCT equipment and work with software developers to fully achieve its potential. The simplest way to achieve this aim is with the use of 2 separate rotations of the same detector with differently positioned and collimated $\mathrm{X}$-ray sources near the top and bottom planes of the FOV (Figure 1, C, shows this geometry schematically). Maybe this method, using 2 single-cycle rapid-rotation scans, can introduce the potential for movement artifact, but on the other hand, it will yield better picture quality relative to other methods. Taking only 1 rotation while increasing both the number and location of the x-ray sources in CBCT scanners with or without the increase of the number of detectors can cause higher x-ray scatter, which in turn will reduce the contrast resolution and increase noise in these images.

In conclusion, with the reconstruction of 2 separate, low-number, basic projection $360^{\circ}$ scans $(300 \mathrm{RD}+$ 300 RD), we achieved better AD fidelity and lower image noise (as one parameter of objective image quality) than other dental CBCT scan modes using the same iCAT Classic equipment. Moreover, in measurements using water and ISI quality-assurance phantom support in this reconstruction configuration (EFOV 04), we were able to obtain better density values (HU) of hard tissues such as compact bone (corresponding to Teflon) or water, and of dense regions of trabecular bone (corresponding to acryl) and soft tissues such as fat (corresponding to LDPE). Even though the present work was done on uniform-density material, nevertheless we may conclude that the use of this dental CBCT reconstruction method results in a considerable improvement in image quality across the entire region, including the density range of the surgical guide materials used in implant surgery.

\section{REFERENCES}

1. Scarfe WC, Farman AG. Cone-beam computed tomography. In: Stuart CW, Michael JP, eds. Oral Radiology: Principles and Interpretation. St Louis, MO: Mosby; 2009:225-237.

2. Miracle AC, Mukherji SK. Conebeam CT of the head and neck, part 1: physical principles. Am J Neuroradiol. 2009;30:10881095.

3. Lagravére MO, Carey J, Ben-Zvi M, Packota GV, Major PW. Effect of object location on the density measurement and Hounsfield conversion in a NewTom 3 G cone beam computed tomography unit. Dentomaxillofac Radiol. 2008;37:305-308.

4. González-García R, Monje F. The reliability of cone-beam computed tomography to assess bone density at dental implant recipient sites: a histomorphometric analysis by micro-CT. Clin Oral Implants Res. 2012;23:1-9.

5. Mah P, Reeves TE, McDavid WD. Deriving Hounsfield units using grey levels in cone beam computed tomography. Dentomaxillofac Radiol. 2010;39:323-335.
6. Metzler P, Zemann W, Lübbers HT, et al. Bone mineral density measurements performed by cone-beam computed tomography in the bisphosphonate-related osteonecrosis-affected jaw. Oral Radiol. 2012;28:101-108.

7. Nackaerts O, Maes F, Yan H, Couto Souza P, Pauwels R, Jacobs R. Analysis of intensity variability in multislice and cone beam computed tomography. Clin Oral Implants Res. 2011;22: 873-879.

8. Mozzo P, Procacci C, Tacconi A, Martini PT, Andreis IA. A new volumetric CT machine for dental imaging based on the conebeam technique: preliminary results. Eur Radiol. 1998;8:15581564.

9. Oliveira ML, Tosoni GM, Lindsey DH, Mendoza K, Tetradis S, Mallya SM. Influence of anatomical location on CT numbers in cone beam computed tomography. Oral Surg Oral Med Oral Pathol Oral Radiol. 2013;115:558-564.

10. Silva IM, Freitas DQ, Ambrosano GM, Bóscolo FN, Almeida SM. Bone density: comparative evaluation of Hounsfield units in multislice and cone-beam computed tomography. Braz. Oral Res. 2012;26:550-556.

11. Azeredo F, de Menezes LM, Enciso R, Weissheimer A, de Oliveira RB. Computed gray levels in multislice and cone-beam computed tomography. Am J Orthod Dentofacial Orthop. 2013;144:147-155.

12. Yamashina A, Tanimoto K, Sutthiprapaporn P, Hayakawa Y. The reliability of computed tomography (CT) values and dimensional measurements of the oropharyngeal region using cone beam CT: comparison with multidetector CT. Dentomaxillofac Radiol. 2008;37:245-251.

13. Araki K, Maki K, Seki K, et al. Characteristics of a newly developed dentomaxillofacial x-ray cone beam CT scanner (CB MercuRay): system configuration and physical properties. Dentomaxillofac Radiol. 2004;33:51-59.

14. Molteni R. Prospects and challenges of rendering tissue density in Hounsfield units for cone beam computed tomography. Oral Surg Oral Med Oral Pathol Oral Radiol. 2013;116: 105-119.

15. Katsumata A, Akiko H, Shinji O, et al. Relationship between density variability and imaging volume size in cone-beam computerized topographic scanning of the maxillofacial region: an in vitro study. Oral Surg Oral Med Oral Pathol Oral Radiol Endod. 2009;107:420-425.

16. Reeves TE, Mah P, McDavid WD. Deriving Hounsfield units using grey levels in cone beam CT: a clinical application. Dentomaxillofac Radiol. 2012;41:500-508.

17. Willi A. Kalender. Computertomographie. 2nd ed. Erlangen, Germany: Publicis Corporate Publishing; 2006.

18. Katsumata A, Hirukawa A, Okumura S, et al. Effects of image artifacts on gray-value density in limited-volume cone-beam computerized tomography. Oral Surg Oral Med Oral Pathol Oral Radiol Endod. 2007;104:829-836.

19. Lagravére MO, Fang Y, Carey J, Toogood RW, Packota GV, Major PW. Density conversion factor determined using a conebeam computed tomography unit NewTom QR-DVT 9000. Dentomaxillofac Radiol. 2006;35:407-409.

20. Khoury F, Hanser Th, Khoury Ch, et al. Komplikationen und Risiken bei augmentativen Maßnahmen. In: Khoury F, ed. Augmentative Verfahren in der Implantologie. Berlin, Germany: Quintessenz Verlags-GmbH; 2009:429-514.

21. Khoury F, Hanser Th, Khoury Ch, et al. Planung und Diagnostik. In: Khoury F, ed. Augmentative Verfahren in der Implantologie. Berlin, Germany: Quintessenz Verlags-GmbH; 2009:41-86.

22. Bryant JA, Drage NA, Richmond S. Study of the scan uniformity from an iCAT cone beam computed tomography dental imaging system. Dentomaxillofac Radiol. 2008;37:365-374. 
23. Swennen GR, Schutyser F. Three dimensional cephalometry: spiral multislice vs cone-beam computed tomography. Am J Orthod Dentofacial Orthop. 2006;130:410-416.

24. De Vos W, Casselman J, Swennen GR. Cone-beam computerized tomography $(\mathrm{CBCT})$ imaging of the oral and maxillofacial region: a systematic review of the literature. Int J Oral Maxillofac Surg. 2009;38:609-625.

25. Tuy HK. An inversion formula for cone-beam reconstruction SIAM J Appl Math. 1983;43:546-552.

26. Schulze R, Heil U, Groß D, et al. Artefacts in CBCT: a review. Dentomaxillofac Radiol. 2011;40:265-273.

27. Köhler TH, Proksa R, Grass M. A fast and efficient method for sequential cone-beam tomography. Med Phys. 2001;28:23182327.
28. Horner K, Islam M, Flygare L, Tsiklakis K, Whaites E. Basic principles for use of dental cone beam computed tomography: consensus guidelines of the European Academy of Dental and Maxillofacial Radiology. Dentomaxillofac Radiol. 2009;38:187-195.

\section{Reprint requests:}

Mark Plachtovics, DMD

Faculty of Dentistry

University of Szeged

Tisza Lajos körút 64

Szeged 6720

Hungary

Plachtovics.mark@stoma.szote.u-szeged.hu; placmark@gmail.com 